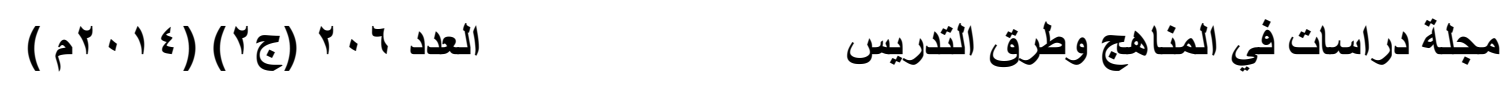

فاعلية برنامج قائم على بعض أدوات الويب · , ץ * في تنمية بعض مهارات

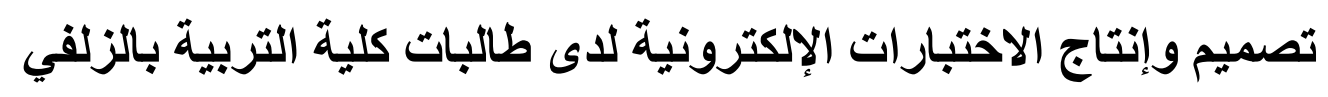

إعداد

د/ أحلام دسوقي عارف إبراهيم

مدرس المناهج وطرق تدريس تكنولوجيا التعليم

بكلية التربية جامعة أسيوط، و جامعة المجمعة

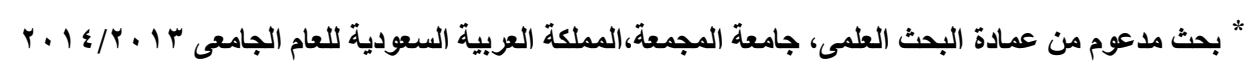




\section{ملخص البحث}

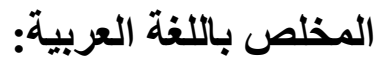

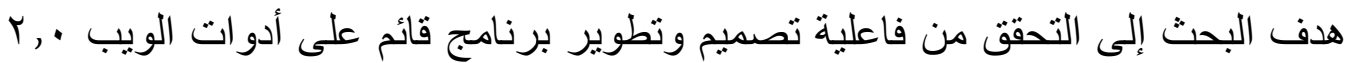
في تتمية بعض مهارات تصميم وإنتاج الاختبارات الإلكترونية لاى طالبات كلية التربية بالز لفي.

وقد اعتمد البحث على التصميم التجريبي ذي المجموعة الواحدة مع الاختبار القبلي

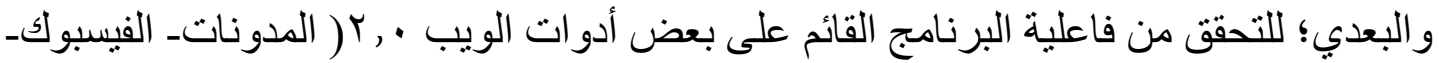
اليوتيوب) في تنمية الجوانب المعرفية، والمهارية المرتبطة بتصميم و إنتاج الاختبارات الإلكترونية لدى طالبات كلية التربية بالزلفي.

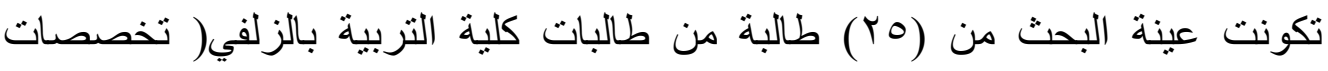

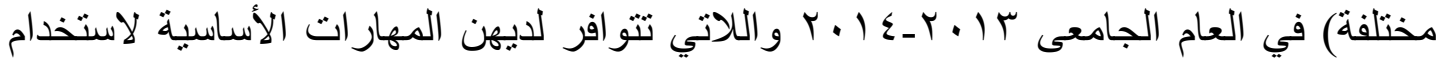

$$
\text { وأسفر البحث عن النتائج التالية: ولائرن حساب على الفيسبوك. }
$$

1ـ التوصل إلى قائمة بالمعايير الجيدة التي ينبغى اتباعها عند تصميم و إنتاج الاختبارات

$$
\text { الإلكترونية. }
$$

r- حقق البرنامج القائم على بعض أدوات الويب . , r فاعلية في تنمية الجو انب المعرفية

$$
\text { لمهار ات تصميم و إنتاج الاختبار ات الإلكترونية. }
$$

r- حقق البرنامج فاعلية في تنمية الجانب الأدائي لدهارات تصميم و إنتاج الاختبارات الإنيات

$$
\text { الإلكترونية. }
$$

ع- حقق البرنامج فاعلية في زيادة مستوى جودة تصميم و إنتاج الاختبارات الإكترونية

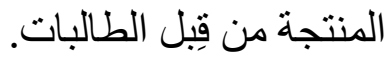




\begin{abstract}
$\underline{\text { Abstract }}$
The present research investigated the effectiveness of designing and developing a program- based on web 2.0 in enhancing designing and producing electronic tests skills among female students at Az Zilfi Faculty of Education. The research adopted the one group pre-posttest experimental group design. The research program was based on some web 2.0 tools such as blogs, facebook, and youtube to develop cognitive and motor-aspects skills of designing and producing electronic tests. The sample of the study consisted of 25 students who have an account on facebook and master the basic skills of using computers and internet.
\end{abstract}

\title{
Findings of the study:
}

1- Developing a list of good/ required standards needed for designing and producing electronic tests.

2- The effectiveness of the program-based on web 2.0 in developing the cognitive skills of designing and producing electronic tests.

3-The effectiveness of the program in developing the performance skills of designing and producing electronic tests.

4- The effectiveness of the program in improving the quality of designing and producing the electronic tests developed by the students. 


\section{فاعلية برنامج قائم على بعض أدوات الويب . , r في تنمية بعض مهارات تصميم وإنتاج

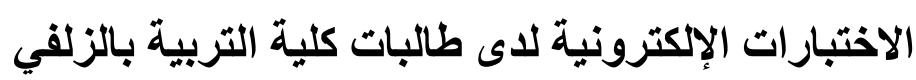

أولاً: المقدمة والإحساس بمشكلة البحث:

أصبح التعليم الإكتروني من الأنماط الجديدة للتعليم و التعلم؛ نتيجة لتطبيق تكنولوالوجيا المعلومات

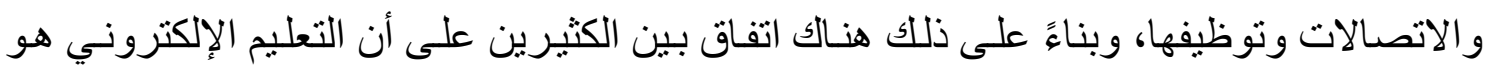

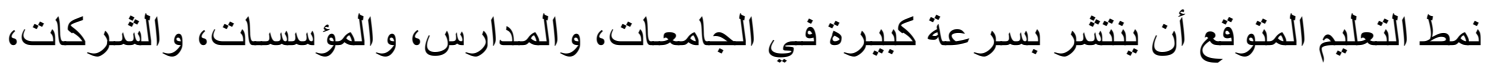
ولدى الأفر اد؛ ويرجع ذلك لما يحمله من ميزات، وفو ائد يمكن أن يحققها لمختلف جو انب الع العملية

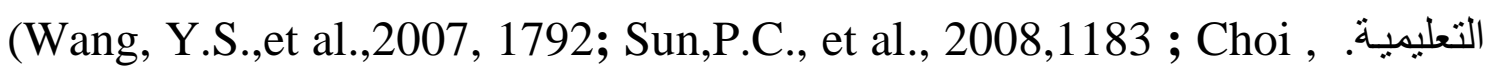

D.H., et al.,2007).

ولقد أكدت أدبيات البحث التربوي أن المعلم هو حجر الزاويـة في العطلية التعليميـة، وأن

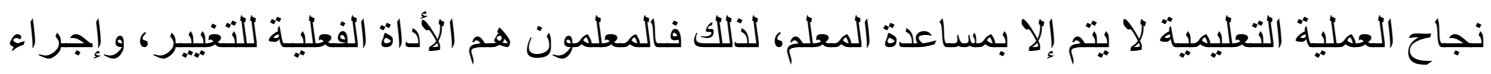

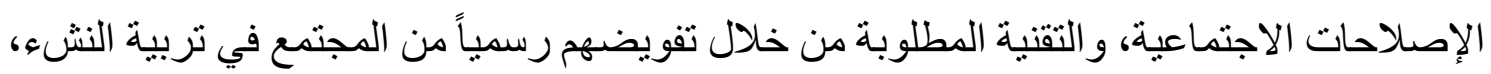
فأي نجـاح لهذه الإصـاحات لن يتحقق إلا بتوفر معلمين أكفاء في التربيـة المهنية، والأكاديميـة المتخصصة.

وفي ظل توظيف التعليم الإلكتروني يتطلب نجاح المعلم كقائد تربوي ضرورة امتلاكه لمجمو عـة من المعـارف و المهار ات المهنيـة و التقنيـة التي تسـاعده في أداء أدو اره المختلفة في التعليم

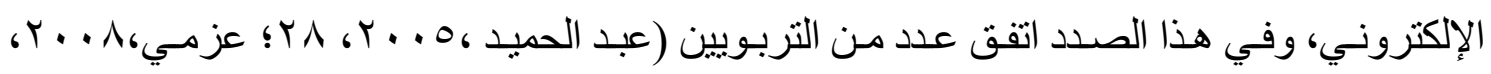

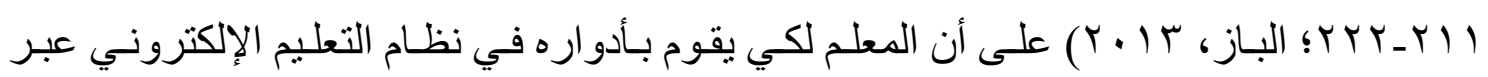

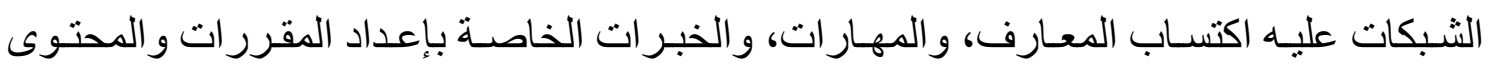
العلمي، بما يتفق مع خصائص البيئة الإلكترونية ومتطلباتها، وطرق بنـاء الاختبار ات الإلكترونية، وتقييم المتعلمين.

علاوة على ما سبق يُشير واقع عملية التقويم باعتباره أحد المكونات الرئيسة التي تتكون منها

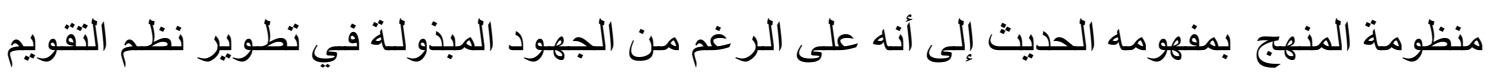

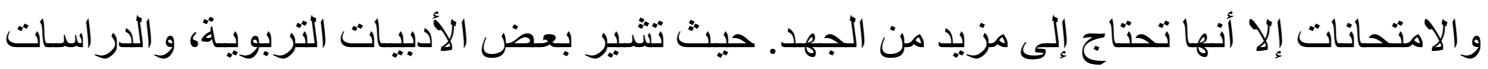

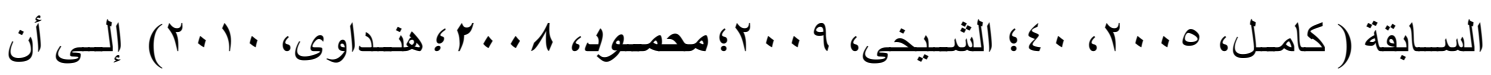

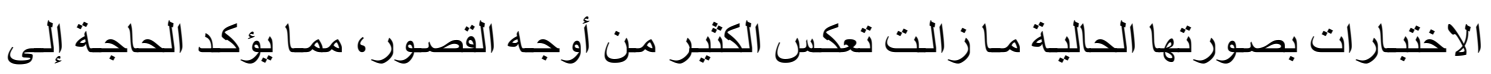


تطـوير فلسـفة وأدوات القيساس و التقويم التربـوي في ضـوء التطـور التكنولـوجي؛ حيـث تهـدف الاختبار ات الإلكترونية بصورتها المعاصرة إلى تحقيق موضو عية القياس، و عدالته، مما يؤدي إلى ولى تطوير التقويم التربوب، وما يترتب على ذلك من تطوير العملية التعليمية .

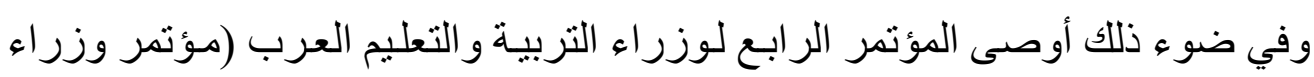

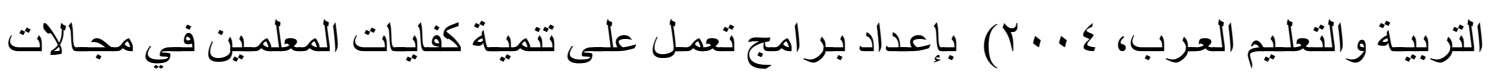

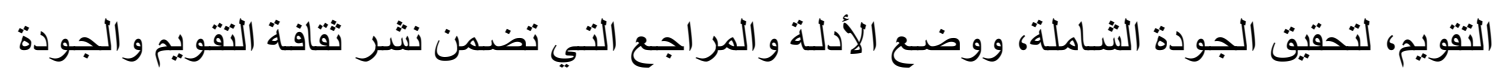
الشاملة بين أوساط التربويين. وبناءً على ما سبق يُعد تصميم و إنتاج الاختبار ات الإلكترونية من أهم ممارسات التعليم في

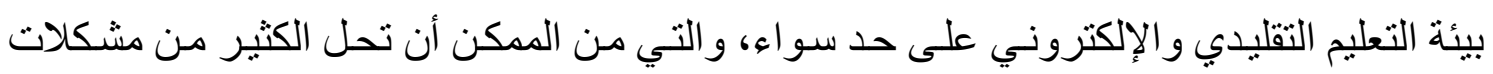
عملية التقويم. حيث اتجهت بعض الدراسـات إلى المقارنـة بين الاختبـار ات الإلكترونيـة و الورقيـة، وذلك

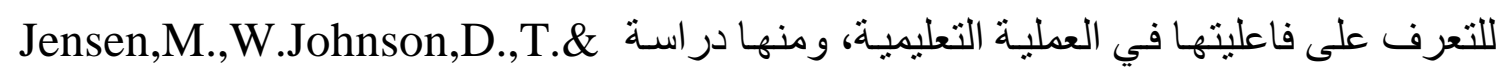
( التي قارنت بين الاختبار التقليدي والاختبـار الإلكتروني لدى عينـة من (Johnson,R., 2002)

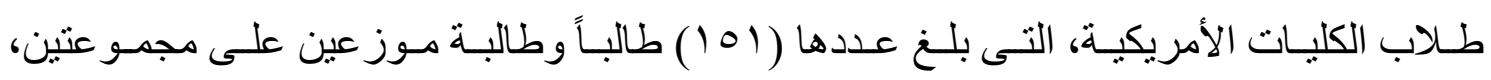

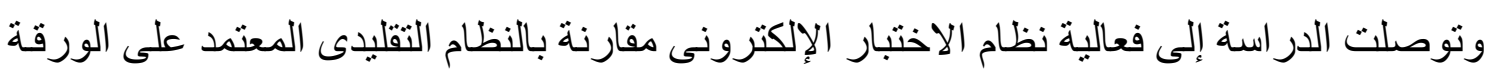
و القلم؛ حيث حققت مجموعة الطلاب الذين نم تطبيق الاختبار الإلكترونى عليهم مستويات تعليمية الإنية

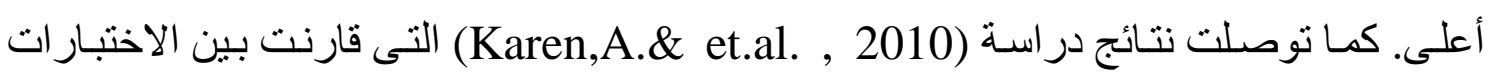

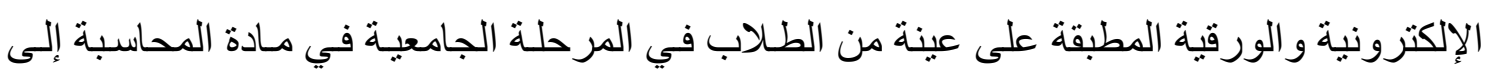

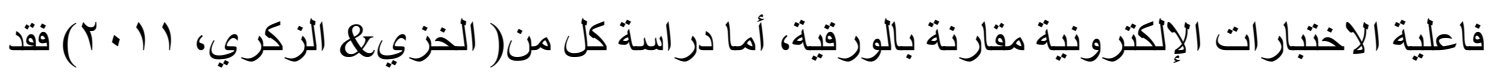
هدفت إلى اختبار مدى التكافؤ بين الاختبار ات الإلكترونية والاختبار ات الورقية في قياس التئس التحصيل

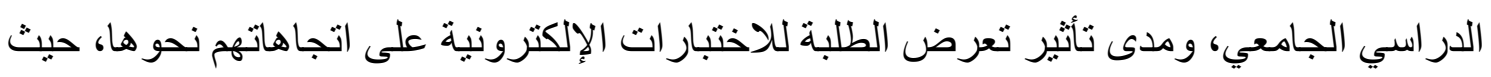

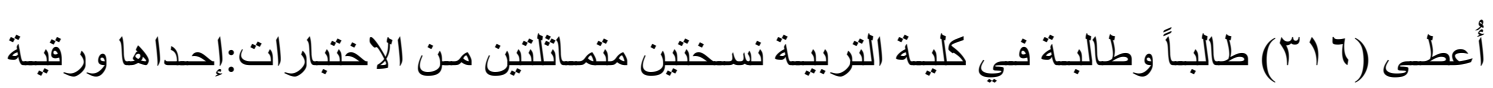
و الأخرى إلكترونية، وأظهرت النتائج ما يلى:

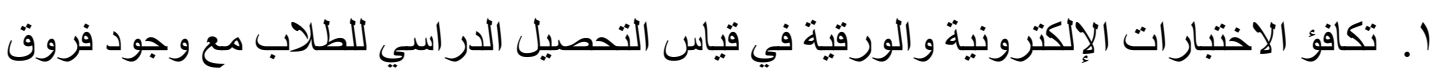

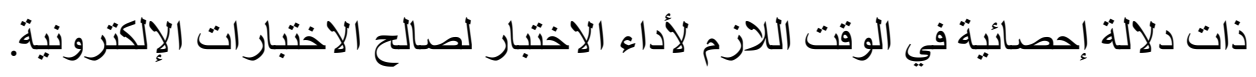

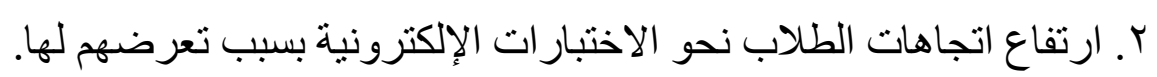


r. أوصت الدر اسة بتبني استخدام الاختبار ات الإلكترونية في التعليم الجامعى في التخصصات التربوية والإنسانية.

أما دراسة (Stowell\&Bennett,2010) فقد قامت على فرضية أن تقديم الاختبارات بطريقة إلكترونية سيؤدي إلى خفض مستوى قلق الاختبار لدى المختبرين؛ ومن ثم إلى تحسين مستوى الأداء والحصول على درجات أعلى في الاختبار، وأجريت الدراسة على (79) طالباً

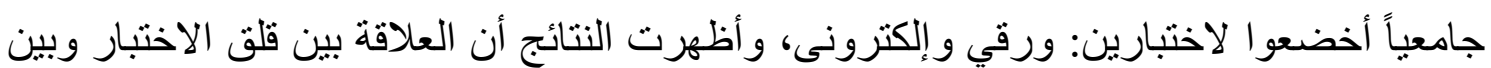
الأداء في الاختبار أضعف في الاختبار ات الإلكترونية منها في الاختبار ات الورقية. من خلال ما سبق يتبين فاعلية الاختبارات الإلكترونية، وأهميتها بالنسبة للعملية التعليمية؛

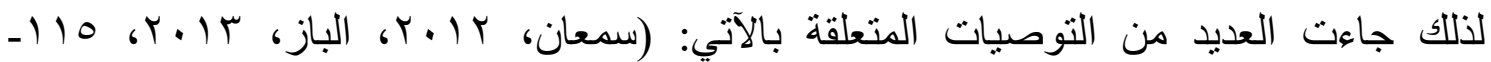

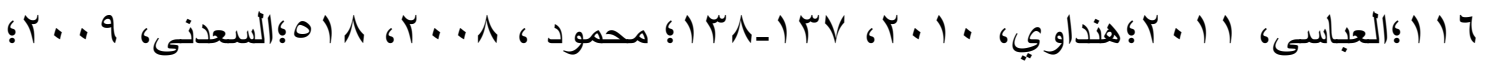

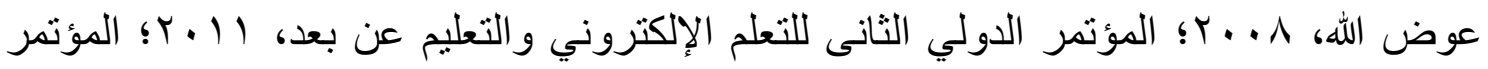

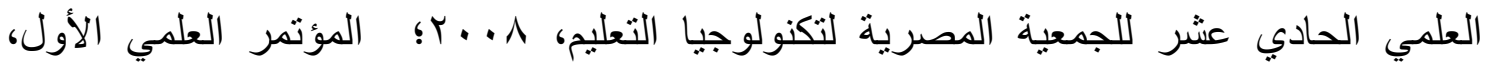
( $($... 1ـ تطوير إعداد الطالب المعلم في كلية التربية؛ وذللك بالإعداد الجيد للمعلم في ضوء التطور

$$
\text { التكنولوجي. }
$$

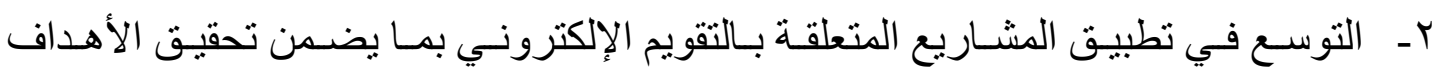

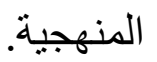

r- ـ زيادة الدعم المادي المقدم لكليات الجامعة؛ لتلبية متطلبات توظيف التقويم الإكترونى.

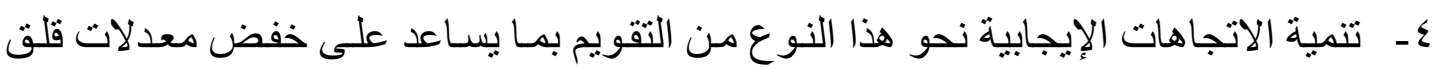

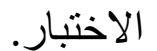
وفي ضوء ما سبق؛ تُعد مهار ات تصميم و إنتاج الاختبار ات الإلكترونية مطلباً أساسياً في ظل توظيف التعليم الإلكتروني، و الجودة الثناملة في العملية التعليمية.

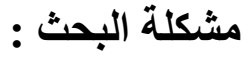
تتكون البيئة التعليميـة للتعليم الإلكتروني من عدة مـكونات منهـا المعلم، ونظر اً لأهمية دور

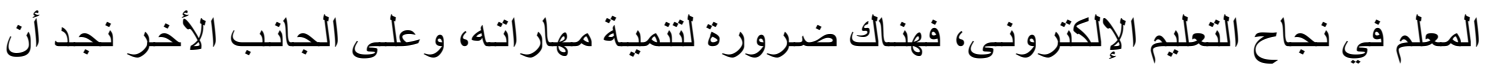
للتقويم أهمية كبرى وجوهرية في التعليم والتعلم؛ فعن طريقه تتحدد درجة تحقق الأهداف التعليمية؛ 
ومن ثم يمكن الحكم على أداء الطلبة وتحصيلهم العلمي ودرجة اكتسابهم للمهار ات و المعارف و العلوم، ولا تتوقف أهمية التقويم عند ذللك، بل إنه يساعد المعلم على تعديل عمليات التعليم و التعلم وتطوير ها. وتحتل الاختبار ات بأنو اعها المختلفة واستخداماتها المناسبة في عملية التقويم جزء عاً مهماً في عملية التعليم و التعلم، وتثغل وقتاً كبير اً من الوقت المخصص للتعليم. ويثبر ( Sutton,2004)

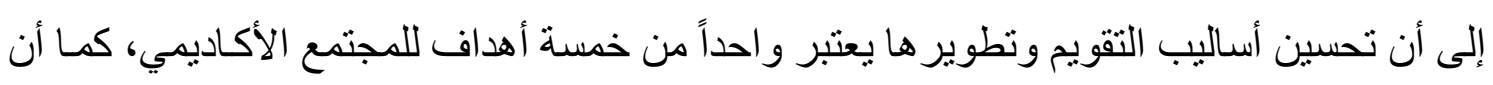

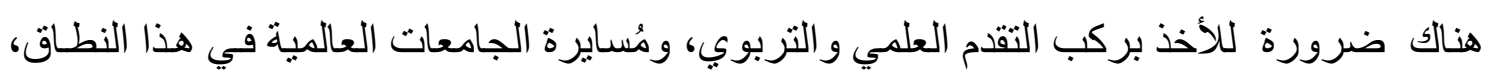

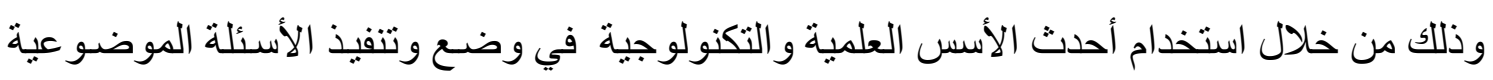
بطريقة صادقة وصحيحة ومنصفة للطالب وللمعلم.

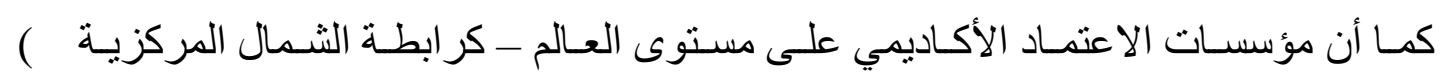

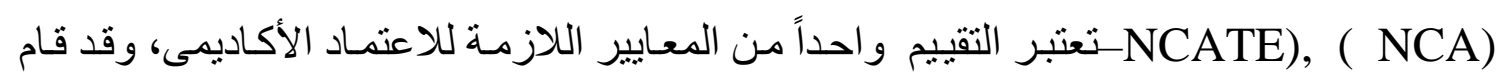
الكثير من تلك المؤسسات بإصدار أدلة تهدف إلى مساعدة المؤسسات التربوية على تطوير وتحسين

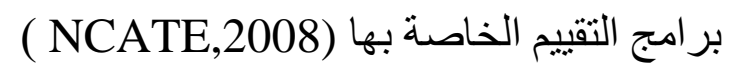
وبالإضافة إلى ما سبق عرضه قامت الباحثة بدر اسـة استطلاعية هدفت إلى التعرف على التى

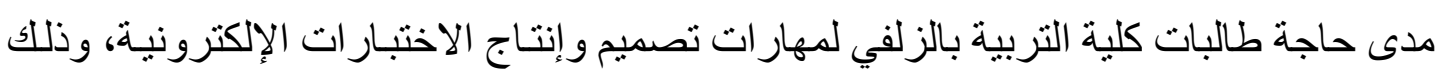
من خلال : 1 . تطبيق استبيان على عينة من طالبات الفرقة الثالثة بكلية التربية بالزلفي؛ وذلك لتحديد مدى حاجاتهن إلى التدريب على تصميم و إنتاج الاختبار ات الإلكترونية.

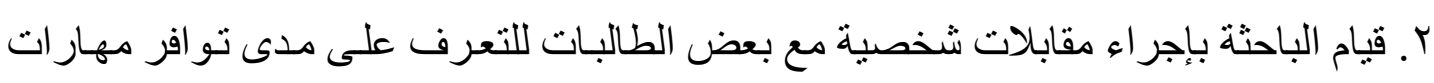

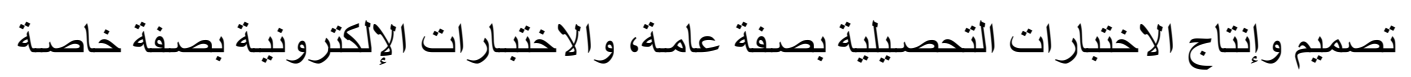
لديهن.

r. فحص توصيف بعض المقررات الدر اسية المقررة في المستويات المختلفة. وقد أسفرت نتائج الاراسة الاستطلاعية عن:

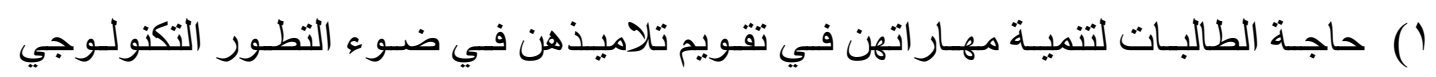
والاتجاهات العالمية المعاصرة. 


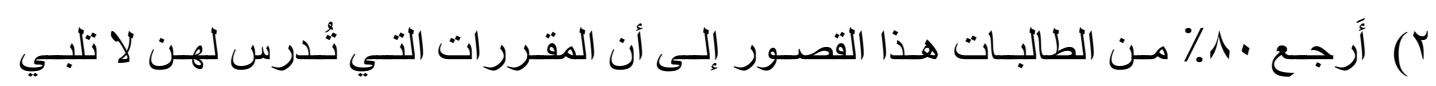
احتياجاتهن فيما يتعلق بتصميم و إنتاج الاختبار ات الإلكترونية.

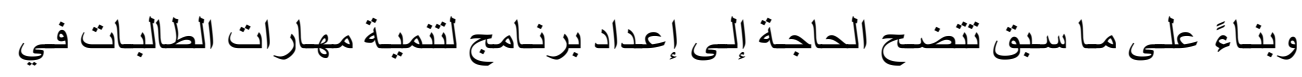
تصميم و إنتاج الاختبار ات الإلكترونية. و بالبحث عن الطريقة التي يمكن من خلالها تنميـة مهـار ات الطالبات في تصميم و إنتاج

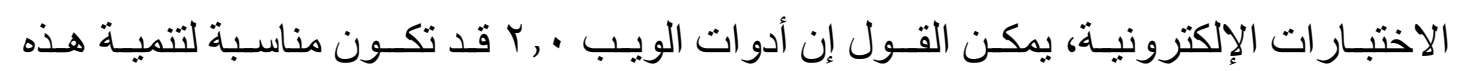

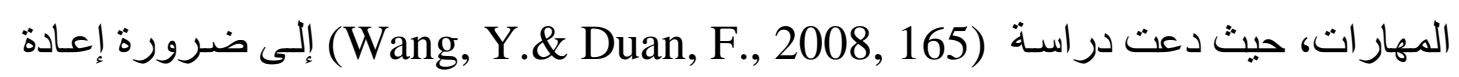

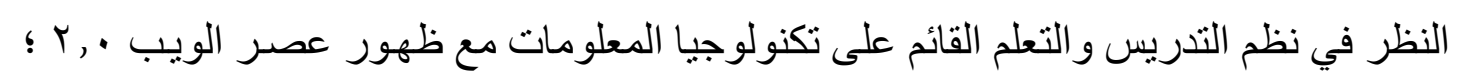

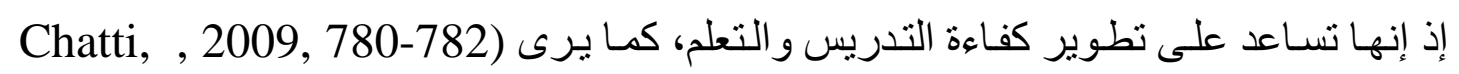
(M., et al.

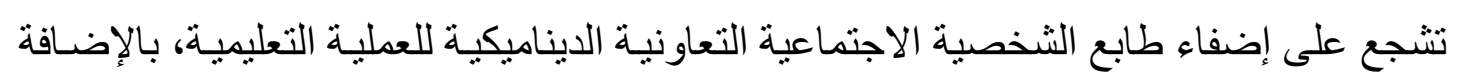

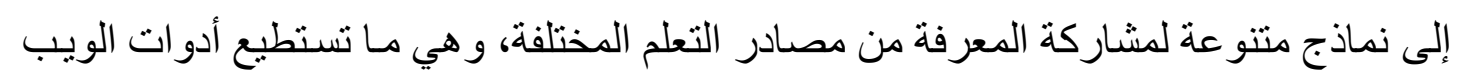

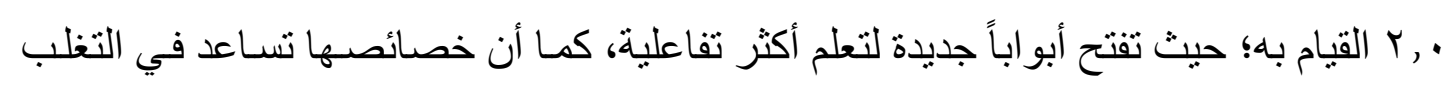
على العديد من القيود التي تواجه العملية التعليمية.

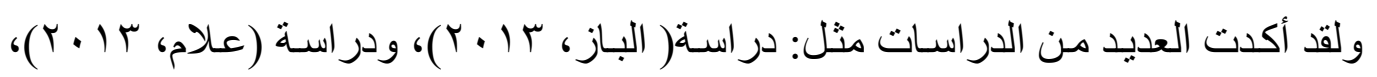

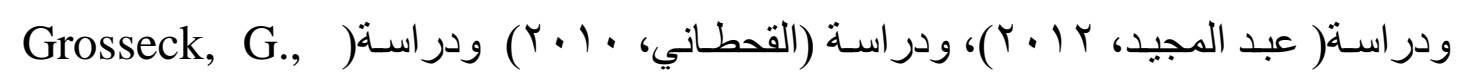

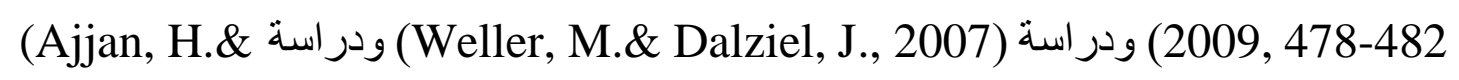
(Greenhow, C., Robelia, B.\& ) ودراسة Hartshorne, R., 2008, 71-80) أهمية أدوات الويب ـ Hughes, J., E. 2009, 280-283) حيث تقدم العديد من التقنيات التي تسهل تقاسم المعلومـات، وتدعم فرص التعاون للمتعلمين، وتنتقل بالمعلم من الدور التقليدي إلى كونه مرشداً وميسر أل للعملية التعليمية.

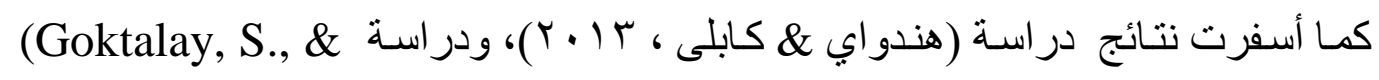
من استعداد المعلمين قبل الخدمة، للاستفادة من Ozdilek, Z., 2010, 2737-2741 ) أدوات الويب • , r ، و الاتجاهات الإيجابية نحو تلك التقنيات، بما يفيد عمليتي التعليم و التعلم.

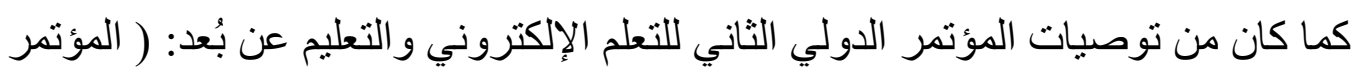

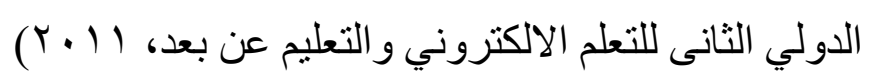


• ضرورة تفعيل دور المقررات الإلكترونية وبيئات التعلم الإلكتروني في مراحل التعليم

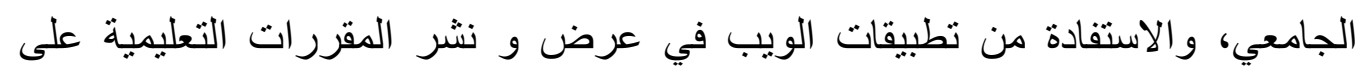

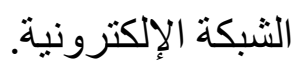

• ضرورة استخدام ونشر ومشاركة المصادر والخبرات التربوية من خلال خدمات الويب مثل: المدونات، و الويكي، ومو اقع مشاركة الوسائط، وخدمات المفضلات الاجتماعية.

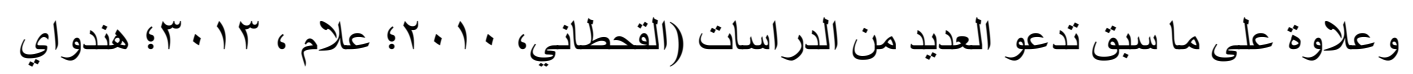

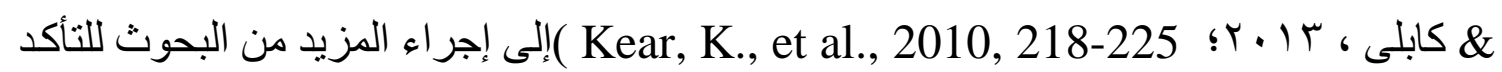
من مدى فاعلية توظيف أدو ات الويب . r r في خدمة العملية التعليمية.

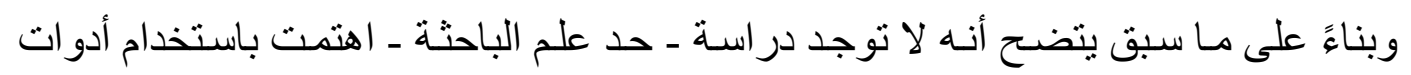

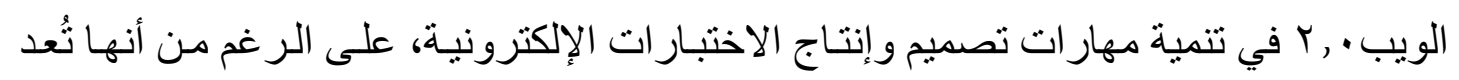

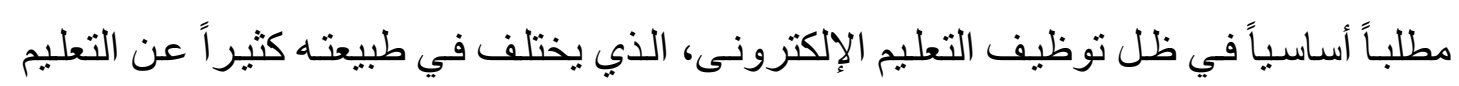

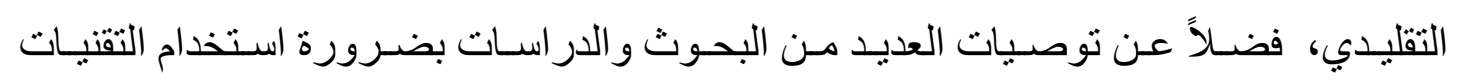

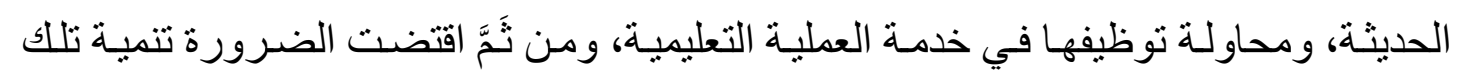
المهار ات مما قد يسهم في الاستفادة القصوى من نللك البيئات. لذا تطلب البحث الحالي الإجابة عن السؤال الرئيس النتالي:

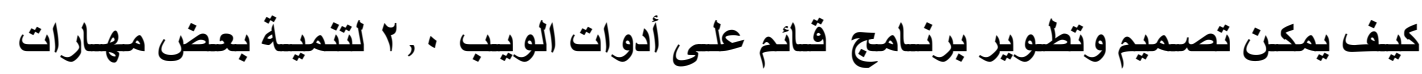

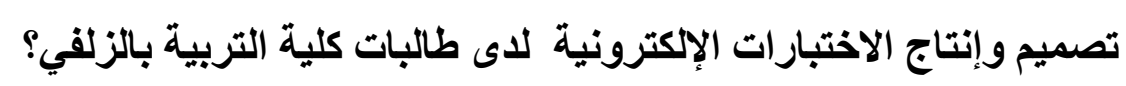
وتفرع من هذا التساؤل الرئيس الأسئلة التالية:

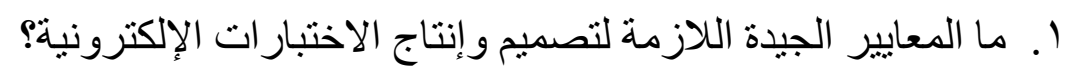

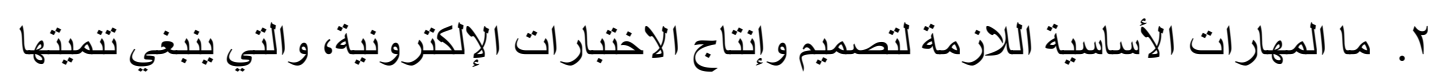
لاى طالبات كلية التربية بالزلفي؟ ماربه

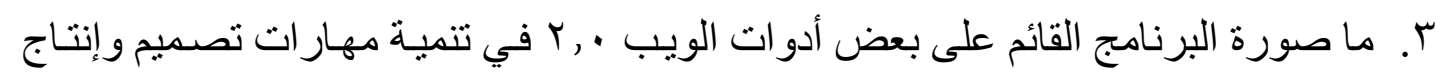

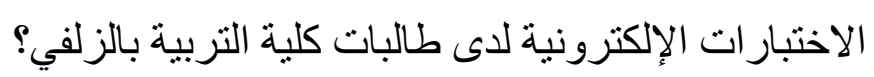

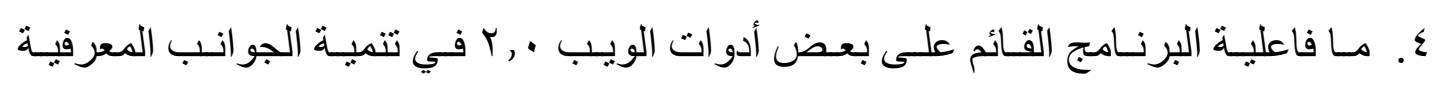

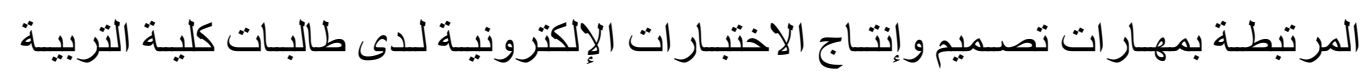
بالز لفي؟ 


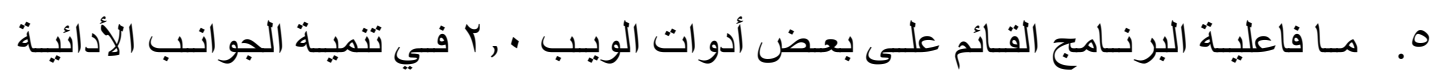

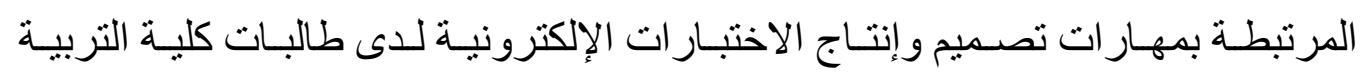

بالز لفي؟.

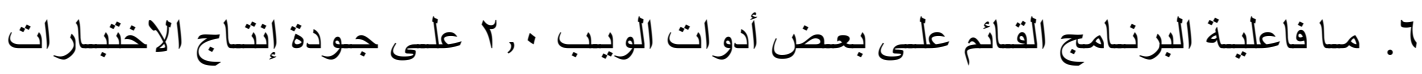

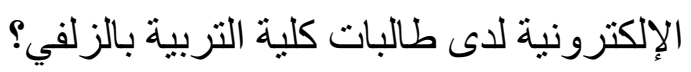

$$
\text { هدف الهداف البحث : }
$$

1 - تحديد المعايير الجيدة اللازمة لتصميم و إنتاج الاختبار ات الإلكترونية.

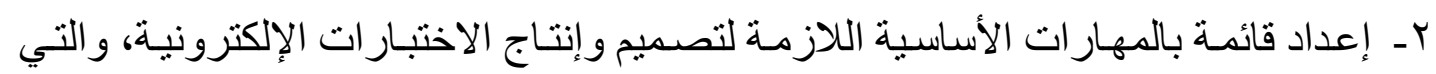
ينبغي تنميتها لدى طالبات كلية التربية بالزلفي.

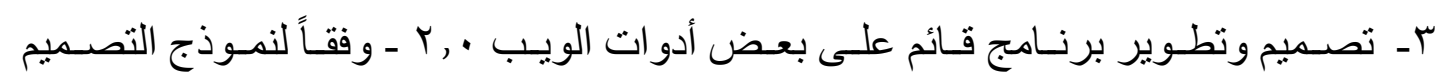
التعليمي- في تنمية مهار ات تصميم، و إنتاج الاختبار ات الإلكترونيـة لدى طالبـات كلية

$$
\text { التربية بالزلفي. }
$$

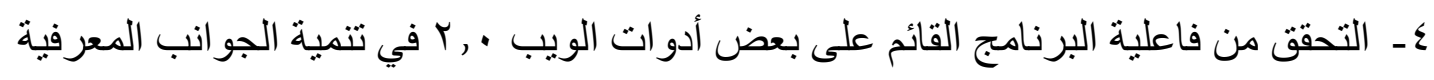

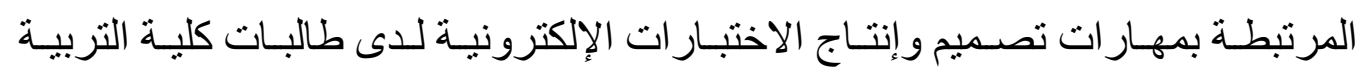

$$
\text { بالز لفي. }
$$

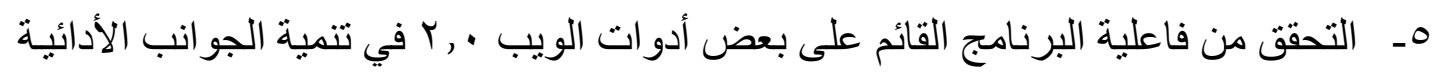

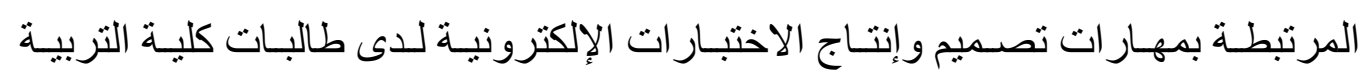

$$
\text { بالز لفي. }
$$

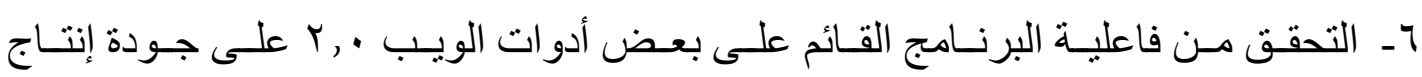

الاختبار ات الإلكترونية لدى طالبات كلية التربية بالزلفي؟ النئ.

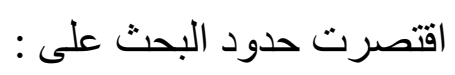

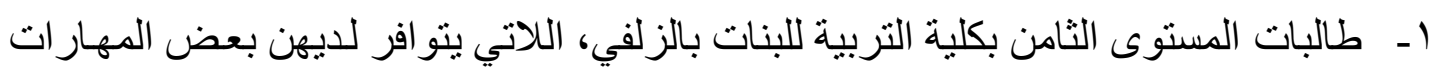
الأساسية لاستخدام الكمبيوتر والإنترنت، ولديهن حساب على الفيسبوك. 


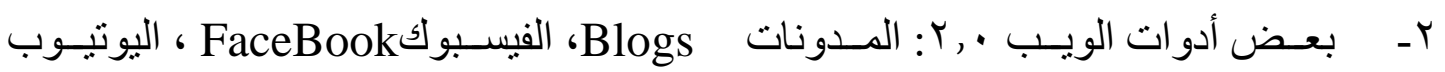
Youtube

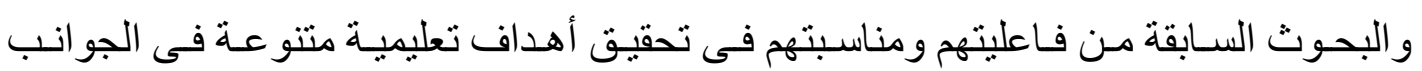
المعرفية، والمهارية، والوجدانية، لمختلف المر احل التعليمية.

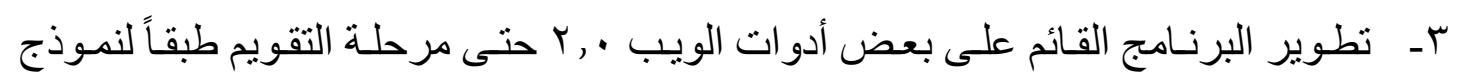

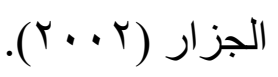

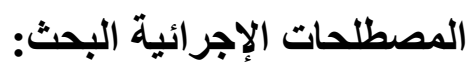
الفاعلية: تُعرف إجر ائياً بأنها " مدى الأثر الذي يمكن أن يحدثه البرنامج القائم على أدوات

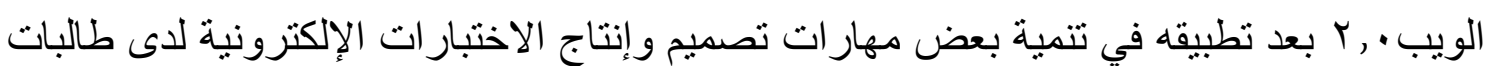
كلية التربية بالزلفي.

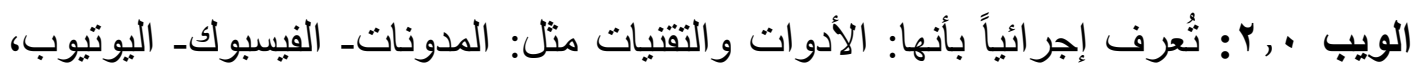

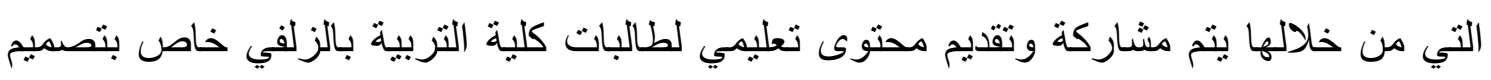

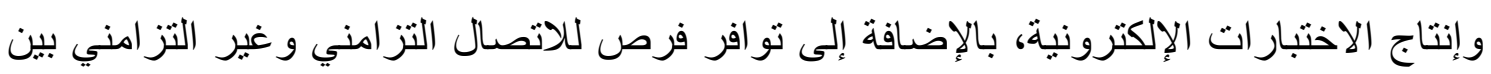

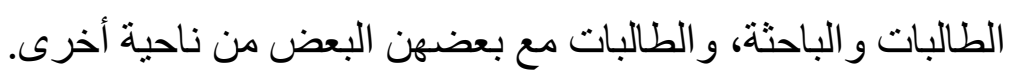

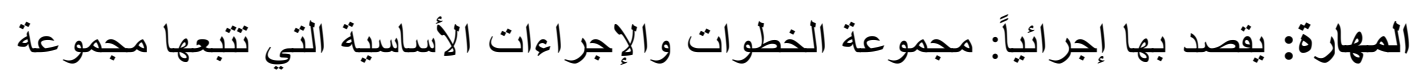

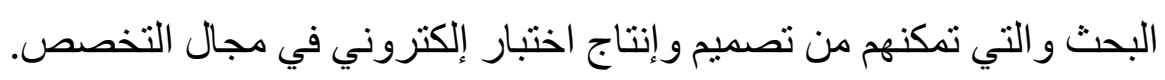

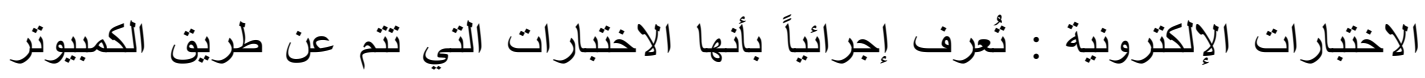
الثخصي، أو شبكة الإنترنت والمصممة في ضوء المعايير الجيدة للاختبار ات الإلكترونية؛ لتقويم أداء المتعلمين إلكترونياً من أي مكان وفي أي وقت الترن.

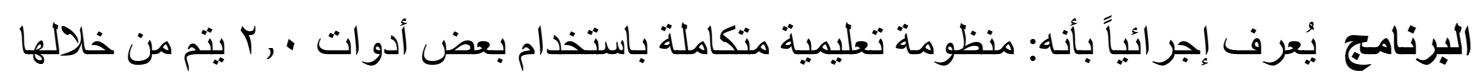

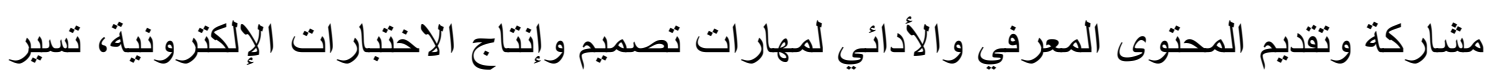

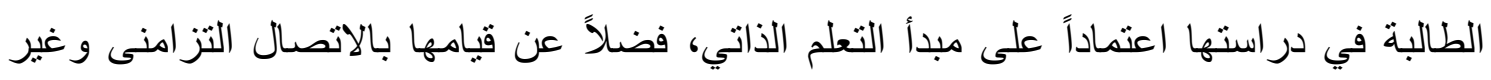

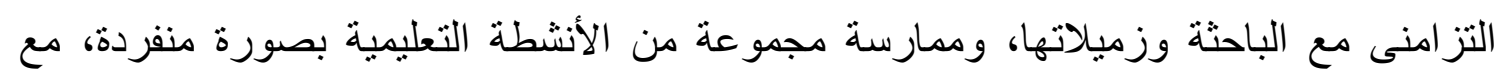

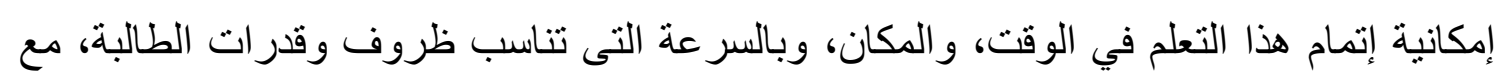
وجود الباحثة ميسرة، موجهة، مناقشة، ومقومة. 


$$
\text { أهمية البحث : ترجع أهمية البحث الحالي فى الجو انب التالية: }
$$

! . يعتبر هذا البحث استجابة للاتجاهات الحديثة المتمة ببرامج إعداد المعلمين قبل الخدمة

بتضمينها مهار ات تصميم الاختبار ات الإلكترونية و إنتاجها.

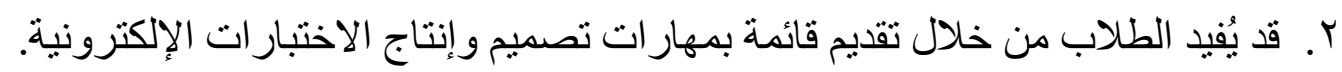
r. قد يُفيد المعلمين و الموجهين من خلال تقديم قائمة بالمعايير الجيدة اللازمة لتصميم و إنتاج الاختبار ات الإلكترونية.

ع. إفادة مخططى برامج التعليم الإلكترونى من خلال تقديم برنامج قائم على أدوات الويب الإبـ

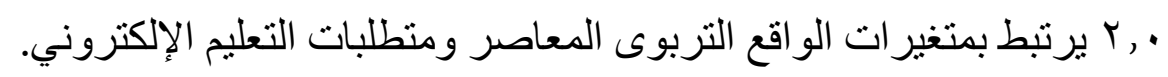
○. قد تُفيد نتائجه في الكثف عن فاعلية توظيف أدوات الويب . r r أحد البيئات التعليمية المرنة و الفاعلة بالمر احل التعليمية المختلفة. T. إفادة المعلمين أثناء الخدمة في تقويم تلاميذهم في ضوء التهلئه التطور التكنولوجي والاتجاهات

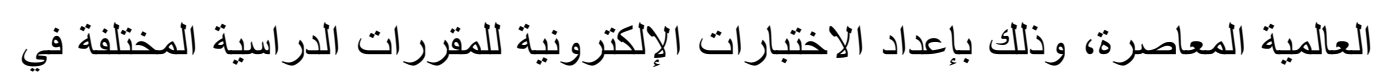

$$
\begin{aligned}
& \text { ضوء تخصصاتهم. } \\
& \text { منهج البحث : } \\
& \text { اعتمد البحث الحالي على: }
\end{aligned}
$$

ـ المنهج الوصفي التحليلي: وذللك عند إعداد الإطار النظري، بناء قائمة المعايير الجيدة اللازمـة

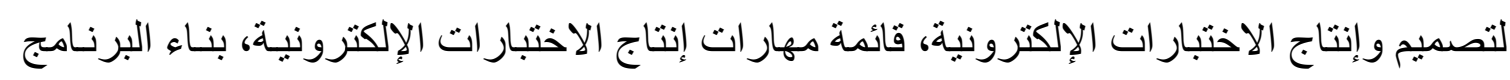

$$
\text { القائم على بعض أدوات الويب . . r، إعداد أدو ات البحث. }
$$

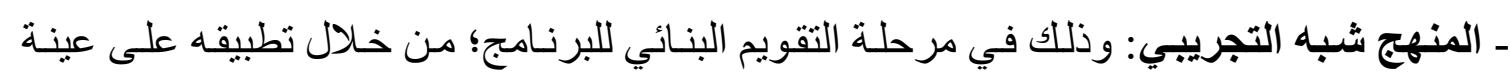

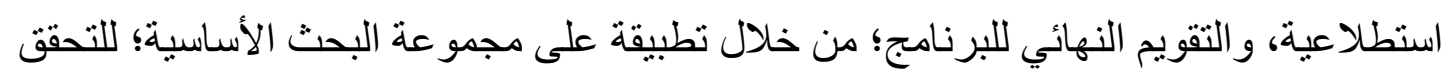

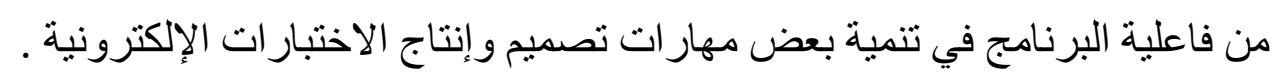

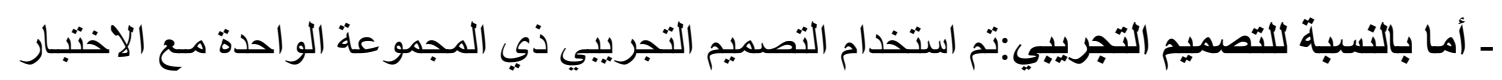

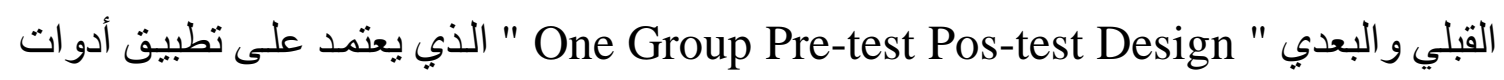
البحث تطبيقاً قبلياً، ثم المعالجة التجرييية التي تتمثل في تطبيق البرنامج على مجمو عة البحث الأساسية، ثم التطبيق البعدي للأدوات، ثم قياس التغير الحادث في التحصيل، والأداء. 
سعى البحث الحالي إلى التحقق من صحة الفروض التالية: •يوجد فرق دال إحصائياً عند مستوى (0 . . • ) بين منوسطي درجات الطالبات (مجمو عة البحث)

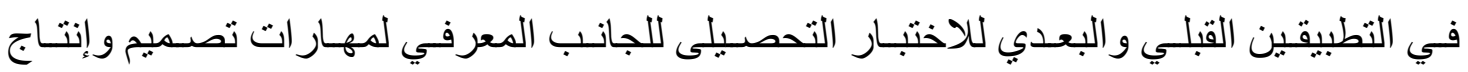
الاختبار ات الإلكترونية لصالح التطبيق البعدي". •يوجد فرق دال إحصائياً عند مستوى (0 . . •) بين متوسطي درجات الطالبات (مجموعة البحث)

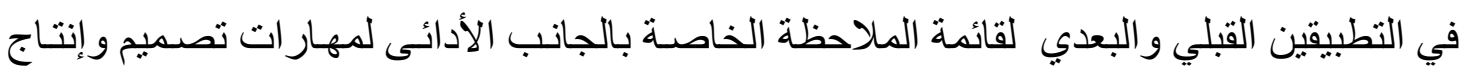
الاختبار ات الإلكترونية لصالح التطبيق البعدي. •يوجد فرق دال إحصائياً عند مستوي (0 . . • ) بين منوسطي درجات الطالبات (مجموعة البحث ) في التطبيقين القبلي و البعدي لبطاقة تقييم جودة الاختبار ات الإلكترونية المنتجـة لصـالح التطبيق البعدي.

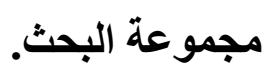

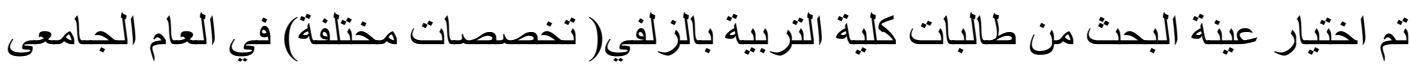

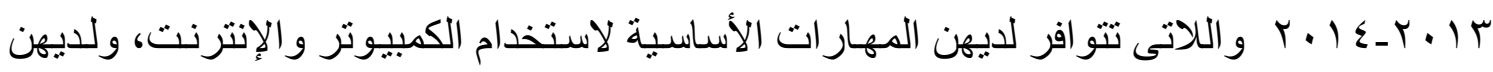

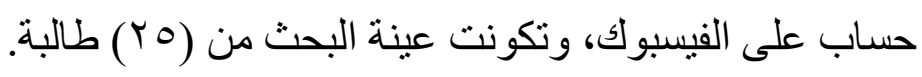
الإطار النظري و الدراسات السابقة

تحقيقاً لأهداف البحث الحالي جاء الإطـار النظرى متتـاولاً العناصر التالية بثـئ من التفصيل:

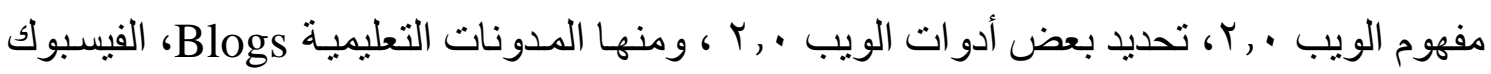

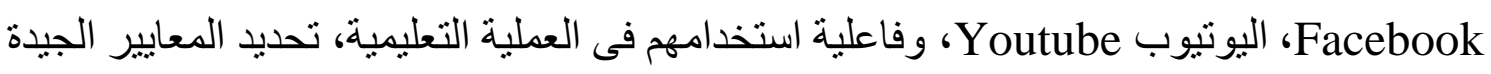
اللازمة لتصميم و إنتاج الاختبار ات الإلكترونية، تحديد المهار ات الأساسية اللازمـة لتصميم و إنتاج الاختبار ات الإلكترونية الجيدة.

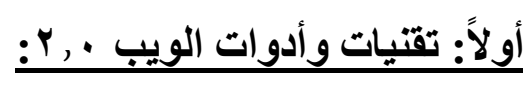

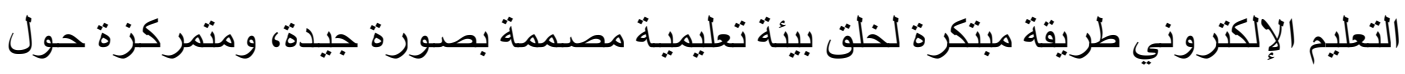

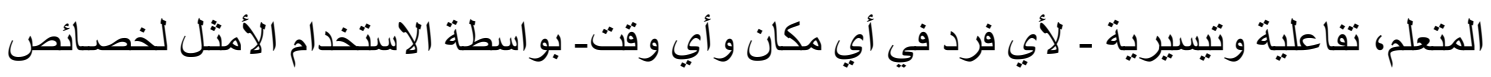
مصادر التكنولوجيات الرقمية المتعددة، بجانب الأشكال الأخرى للوسيائل التعليمية المناسبة للبيئة

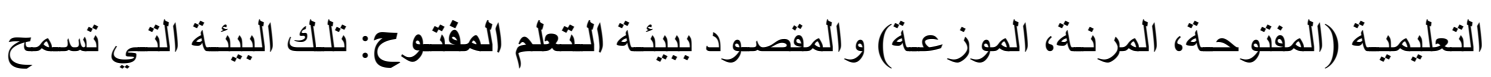


للمتعلم بالتعلم في أي وقت و أي مكان وبالسر عة المناسبة لقدرات المتعلم واستعداداته، فأما بيئة

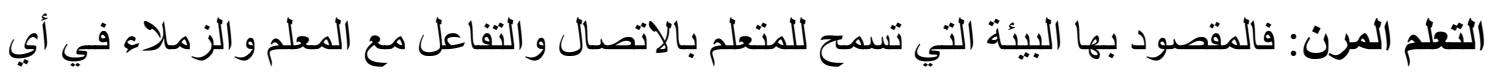

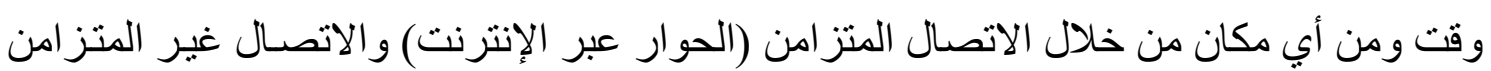

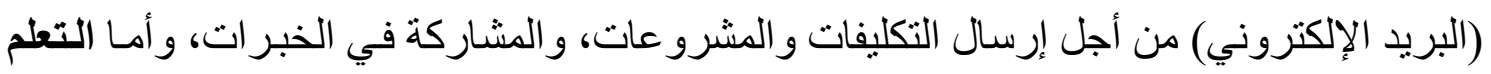

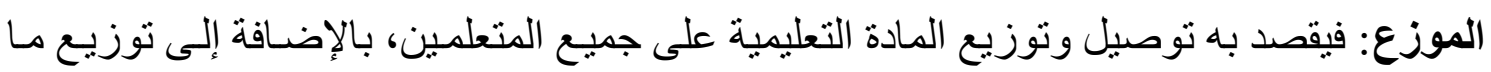

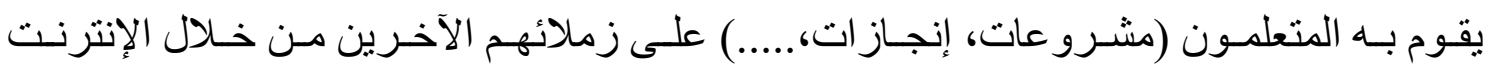
. (Khan,B.,2005, 3)

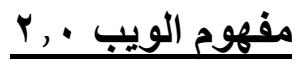

مع تطور تكنولوجيا التعليم الإلكترونى ظهرت نو عية جديدة من الأدوات أصبحت ذات شهرة

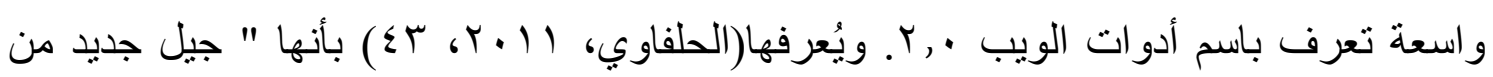

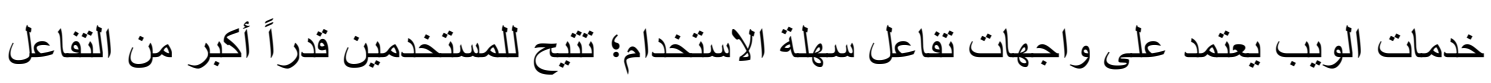
و التثارك و التعاون في بناء و إدارة محتوى تفاعلي في إطار اجتماعي يحافظ على وجود علاقات إنسانية بين المستخدمين".

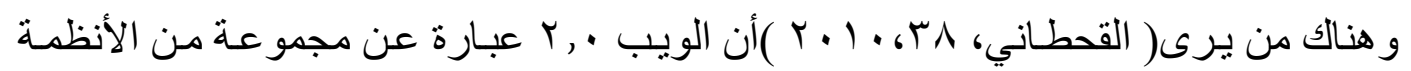
المستندة إلى الويب، و التي تتضـمن عناصـر تتيح للمستخدم الدخول و التفاعل مـع مستخدمين آخرين، أو مع محتوى مقدم من قِبل هؤلاء المستخدمين، ويكون هذا التفاعل في صور عدة أهمها:

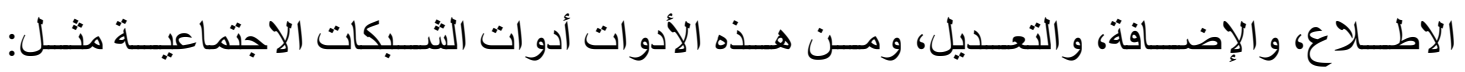

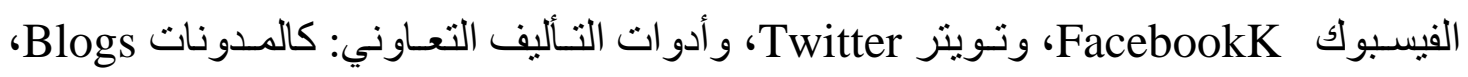
و الويكي Wiki.

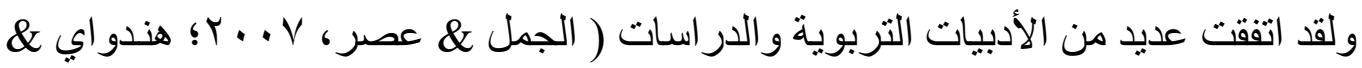

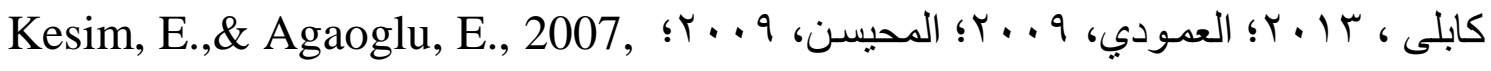
(Zheng , et.al.,2009؛ Anderson, P., 2007 ؛ Cocciolo, A., 2010 ؛ 70-71 أهمية الويب . . r لجميع المنظمات التعليمية و غير ها بما تتضمنه من وسائل تساعد على الانتقال

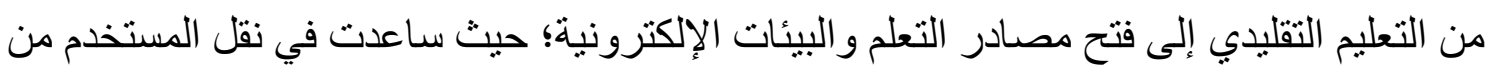

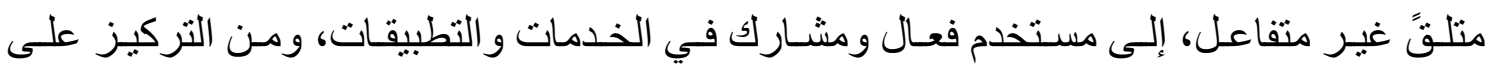
المحتويات مسبقة الإعداد إلي وسائط تفاعلية، يتم إنتاجها عن طريق المستخدم الذي يتشـارك فيها

\section{rᄉ}


مـع الآخرين من خـلال: التعديل، إدر اج تعليقات، وتحميل ملفات، دون الحاجة إلى معرفة لغات

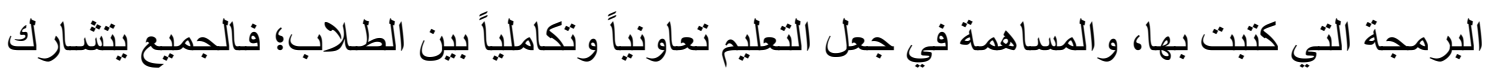

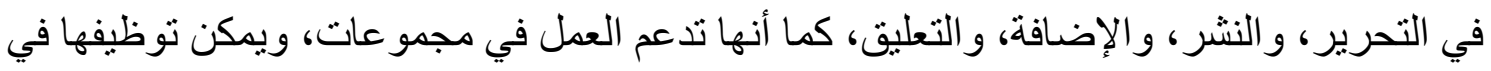

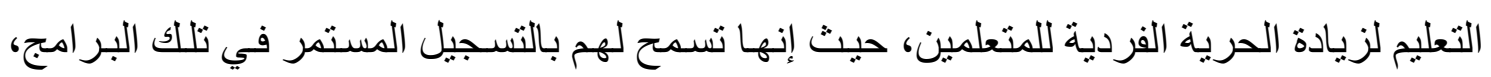
و استخدامها وفقاً لخطو هم الذاتي. و هناك الكثير من الدراسات التي اهتمت بالتعرف على فاعلية استخدام أدوات الويب . . ب في

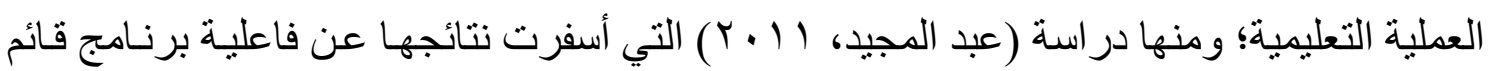

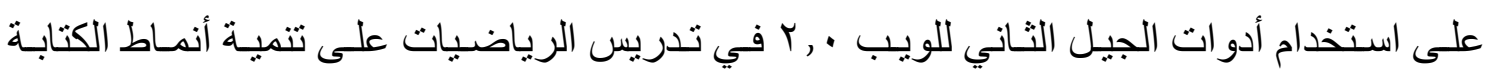

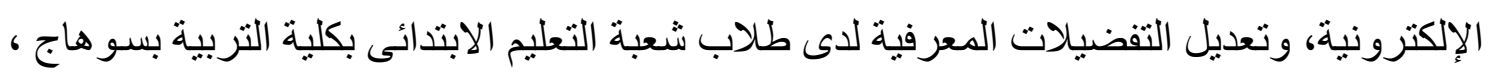

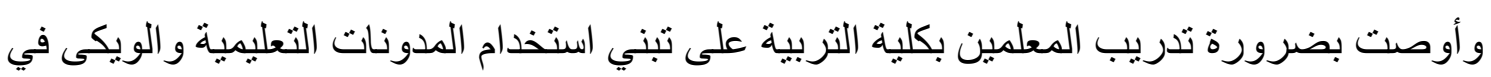
تدريس مقرار اتهم المختلفة.

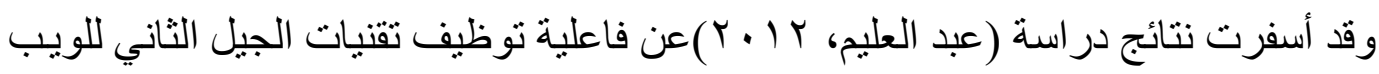
في تنمية مهار ات تصميم المقررات الإكترونية لاى معلمي المدارس الذكية، كما نوصلت نتائج

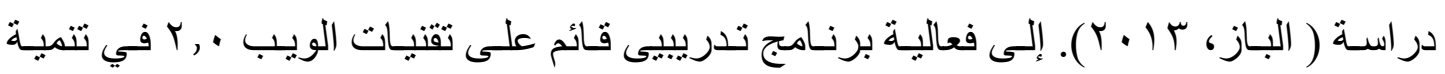

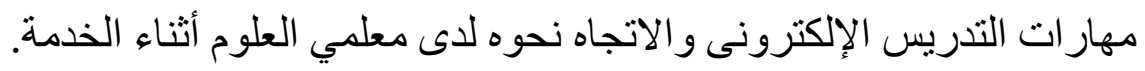

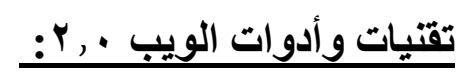

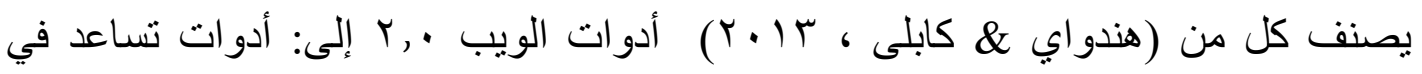

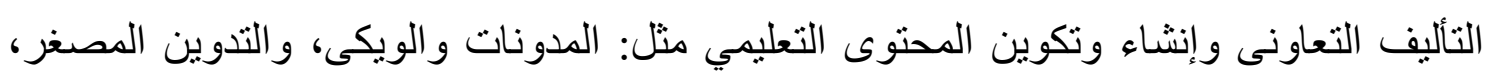

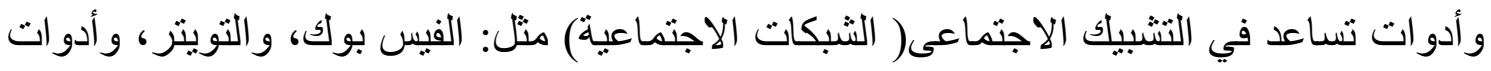

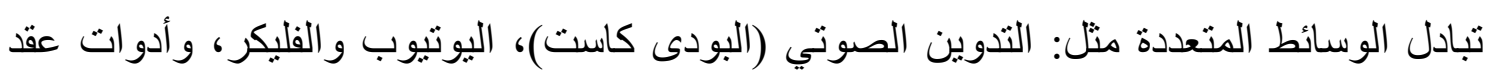

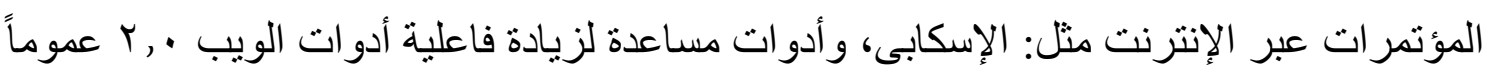

مثل: المفضلة الاجتماعية Social Book marking.. ومن الملاحظ تعدد وتتوع أدوات الويب . . r وفيما يلي عرض لأهم تلك الأدوات والتي قام

\section{عليها البحث المدونات التعليمية Blogs:}

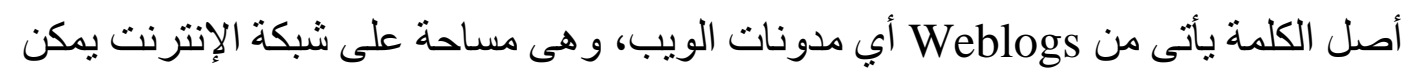

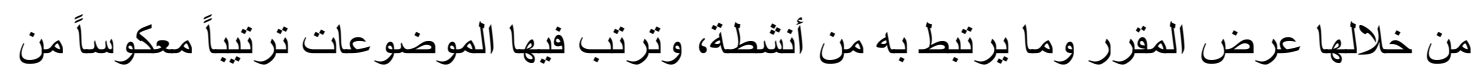


الأحدث إلى الأقدم، وتتعدد محتوياتها فقد تكون نصوصاً، أو صوراً، أو فيديو، كما يسنطيع الطلاب و المعلم تبادل المناقثات خلالها. (Churchill,2009,180). وهناك الكثير من الاراسات التي اتجهت نحو التعرف على فاعلية استخدام المدونات في

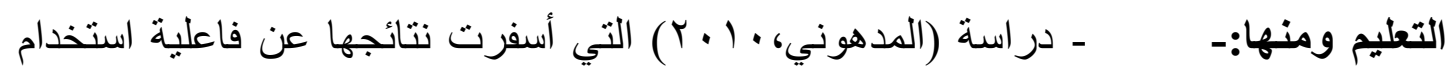
المدونات التعليمية في تتمية التحصيل الدراسي لدى طالبات قسم اللغة الإنجليزية في مقرر الوسائل وتقنيات التعليم و الاتجاه الإيجابى نحو ها.

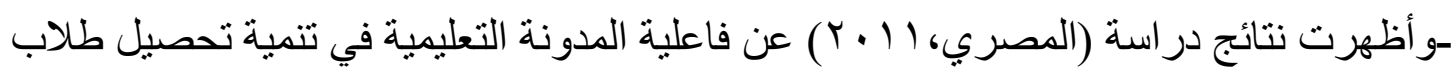
المرحلة الإعدادية للمفاهيم المجردة لمادة الكمبيوتر و الاتجاه نحو المادة.

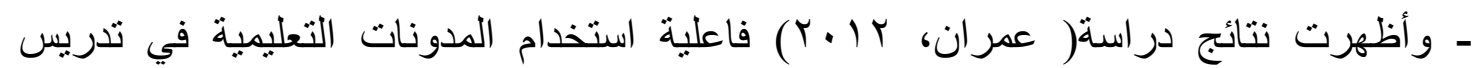

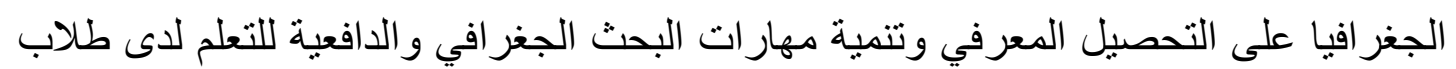

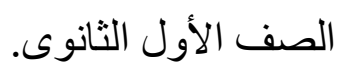

ـأما دراسة (Churchill,2009) فقد هدفت إلى تعرف أثر استخدام المدونات في التعليم

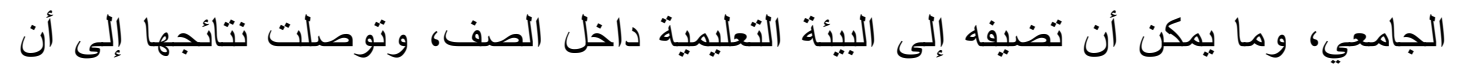
استخدام الددونة ساعد على تتمية التحصيل الدراسي لدى الطلاب، كما اتفق الطلاب المشاركون في الدراسة على أن المدونة ساهمت في تيسير تعلمهم، وتعلمهم أثنياء جديدة -بعد مشاهدتهم لأعمال الآخرين- وقد أبدى معظم الطلاب رغبتهم و استعدادهم لعمل مدونات في المستقبل.

:Facebook الفيسبوك

يعتبر موقـع Facebook شـبكة اجتماعيـة يمكن الــخول إليـه مجانـاً، وتـديره شـركة

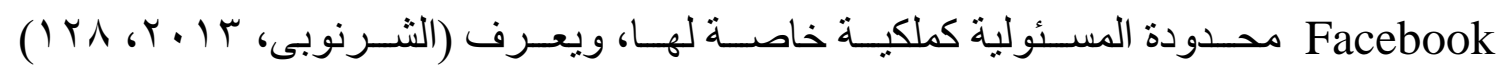
على أنه موقع أو صفحة على شبكة الإنترنت، تجذب إليها عدداً كبير اً من المستخدمين

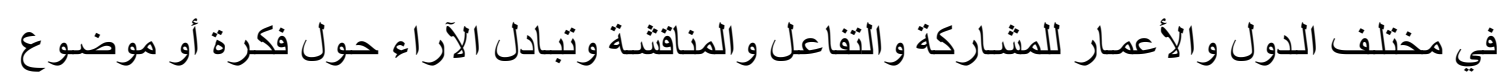

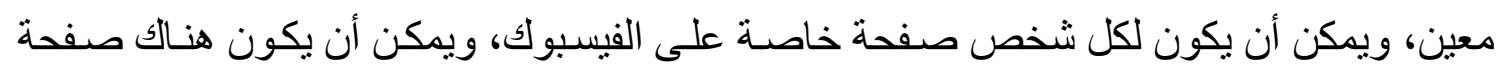

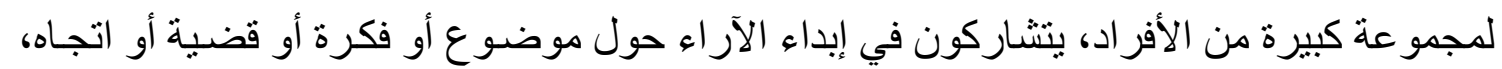

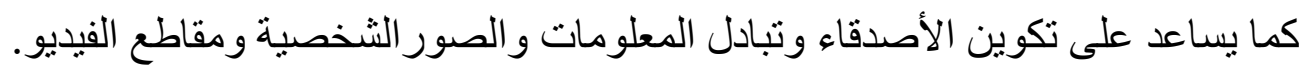


وقد أثنار ( Gabriela ,G\& et al., 2011 ) إلى أن مواقع الثبكات الاجتماعية أصبحت

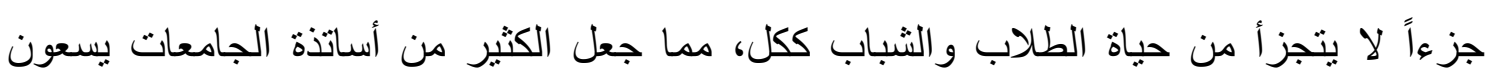
لتوظيف الثبكات الاجتماعية على المستوى الأكاديمي، وليس فقط على المستوى الاجتماعي، حيث ليثل يمكن استخدامها لأشياء كثيرة مختلفة فيما يتعلق بالتعليم النظامي.

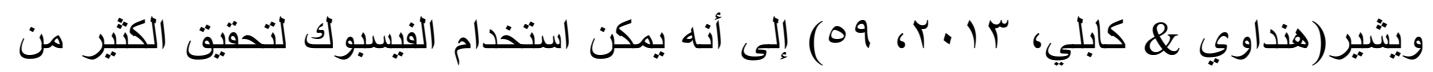

الجو انب المرتبطة بالعملية التعليمية أهمها: • المشاركة في الأنشطة التعليمية وسهولة تبادل المعلومات، و إتاحة الفرصة للتعليق على ما

ينشر.

• بساعد المعلمين في نشر دروسهم و الإعلان عنها مع الاعتماد على الوسائط المتعددة.

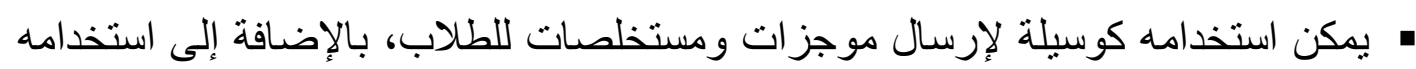

$$
\text { لتذكير الطلاب بواجباتهم، والأحداث المقبلة. }
$$

وعن فاعلية موقع الفيسبوك في العملية التعليمية أسفرت نتائج دراسة (إبراهيم، (1) بـ) عن وجود فروق دالة إحصائيا بين متوسطي درجات الهجموعة التجريبية الأولى التى تلقت

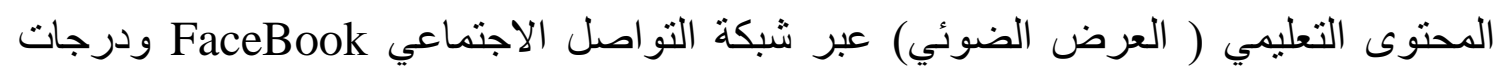
المجموعة التجريبية الثانية التي وجهت لعناصر المحتوى التعليمي ليتم البحث عنها في الإنترنت (البحث الموجه عبر الإنترنت) في القياس البعدي في الاختبار المعرفي لصالح المجموعة التجريبية

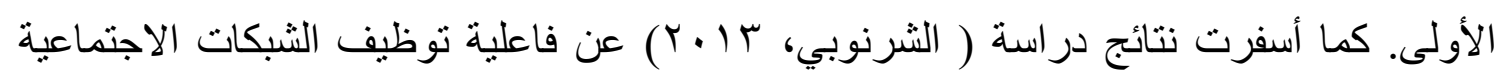
(الفيسبوك) المصاحبة للمواقع التعليمية في تنمية كل من التحصيل، ومهارات تثنغيل واستخدام

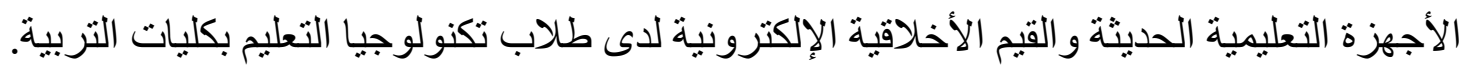

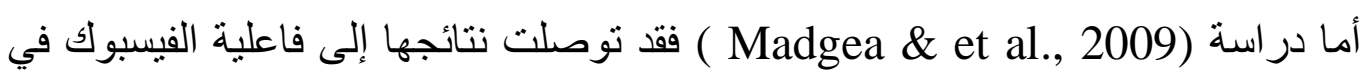
إكساب الطلاب المهارات الاجتماعية اللازمة للتعلم والتفاعل الإجتماعي، وتحقيق الأهداف

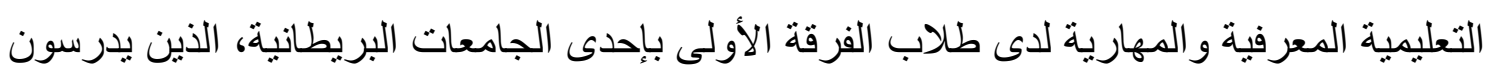
مقرراً في الحاسب الآلي عبر الويب. وأكدت دراسة (Freishtat,R.L.,2009 ) فاعلية توظيف الفيسبوك في التعليم الجامعى بصفة عامة، نظراً لقوة نأثير وإمكانية التحكم ومقابلة احتياجات

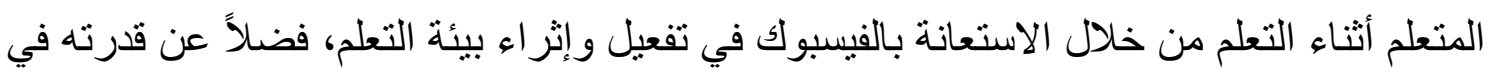

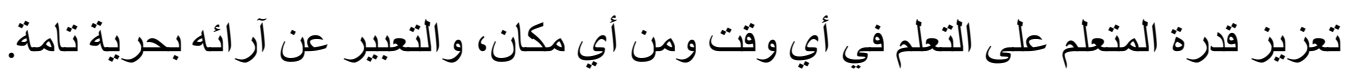




\section{اليوتيوب Youtube}

من المبادئ الأساسية في التعليم إثر الك أكبر قدر ممكن من الحواس في التعليم، حتى يكون

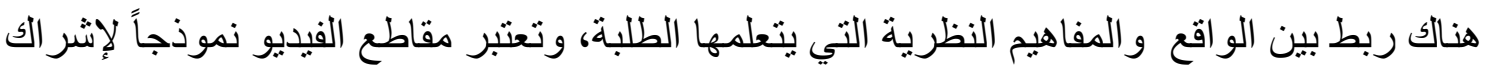

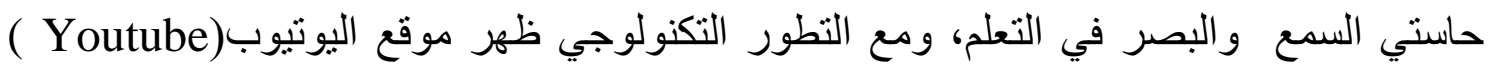
الذي يعتبر أحد أهم أدوات الجيل الثناني للويب، الذى يسمح للمستخدمين برفع ومشاهدة ومشاركة مقاطع الفيديو بشكل مجاني. ومن خصائص موقع اليوتيوب أنه يشجع على الإبداع، لكونه يوفر فرصة للمتعلمين للتفاعل وليس مجرد مشاهدة المحتوى، مناسب لتعليم المتعلمين بمراحلهم المختلفة؛ حيث يمكن استخدامه في التعليم مدى الحياة، كما يُعد أحد موارد التعليم والتعلم المجانية.

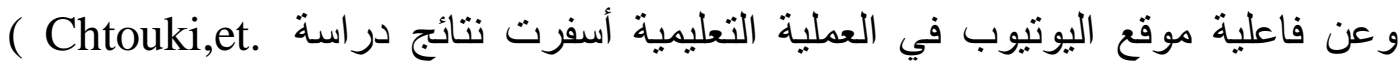
al,2012) عن فاعلية استخدام اليوتيوب في تعزيز تعلم الطلبة، وتقويم مهار اتهم في مساق مقدمة في علوم الحاسب الآلى، أوصت الدراسة بجعل اليوتيوب مصدراً تعليمياً بستخدمه التربويون

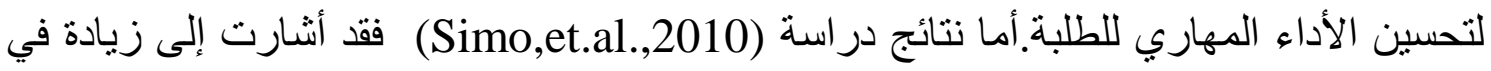
دافعية الطلبة نحو التعلم نتيجة استخدام مو اقع بث الفيديو، بالإضافة إلى أن تللك المو اقع تثجع العمل التعاوني، وتحدث نوعا من التكامل في المعرفة بين المقررات الدراسية، وأوصت الدراسة

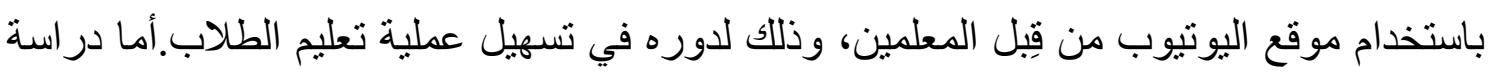
فقد هدفت إلى تحديد وجهة نظر الطلبة من استخدام اليوتيوب في (Snyder \& Burke,2008)

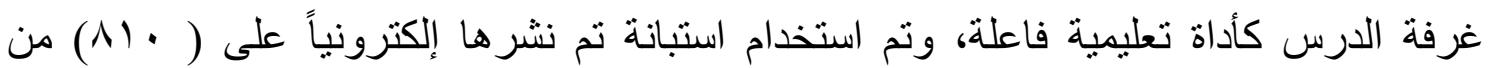
الطلاب الذين يدرسون مقرر الصحة العامة، أوصت الدراسة بضرورة استخدام اليوتيوب في غرفة التنريس، وتحديد سياسة لنطوير قدرات المعلمين لاستخدامه في التعليم، مع تزويد الأقسام و الوحدات في الجامعة بآليات لدعم استخدامه في قاعات الدراسة. من خلال العرض السابق للإطار النظرى و الدر اسات السابقة اتضح ما يلى: لإنى

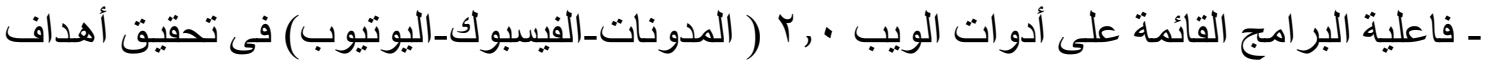
تعليمية متتو عة فى الجو انب المعرفية، و المهاريـة، والوجدانيـة فضلاً عن التقليل من زمن التعلم، وزيادة معدلات الاحتفاظ به؛ وذللك لما تحمله تلك الأدو ات من إمكانيات تتمثل فى تقديم المحتوى

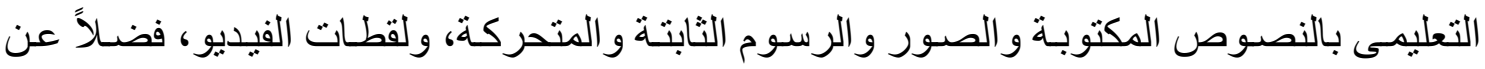


إتاحـة فرص المشـاركة فى الأنشطة التعليميـة وسـهولة تبـادل المعلومـات، و إتاحـة فرص مناقثـة عناصر المحتوى التعليمى والتعليق على ما ينشر، مما يساعد فى تحقيق مستوى أعلى من الإتقان،

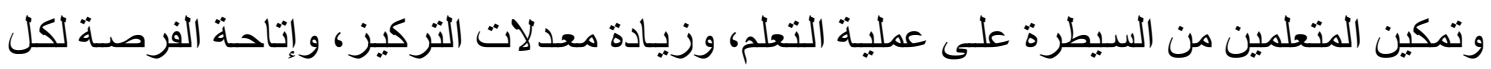
متعلم للتعلم بطريقة فردية، وتعاونية تثاركية.

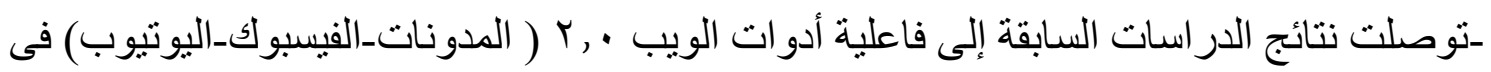
تدريس مو اد در اسية متعددة ومع مر احل تعليمية مختلفة.

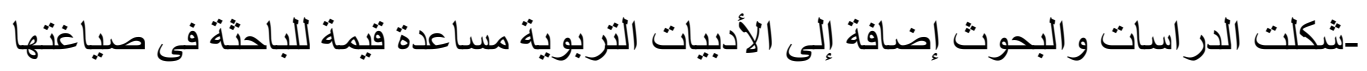

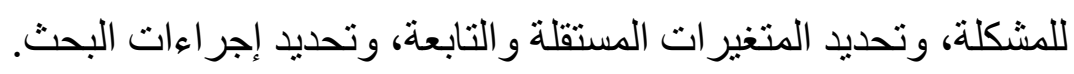

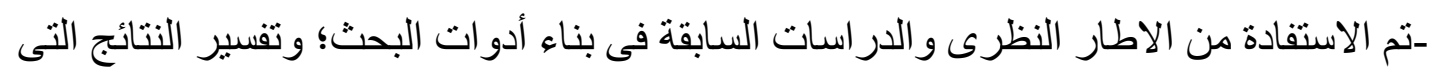

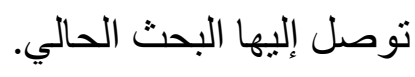
ثانياً: الاختبارات الإكترونية: مفهوم الاختبارات الإكترونية:

الاختبار ات الإلكترونية هي التي تتم بواسطة تقنيات الكمبيوتر وشبكاته؛ فمن خلالها يتم القيام

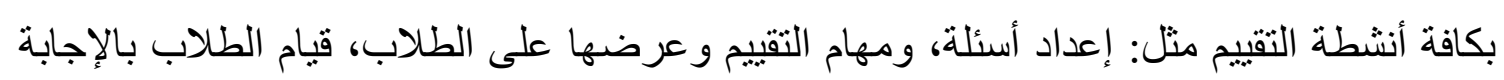

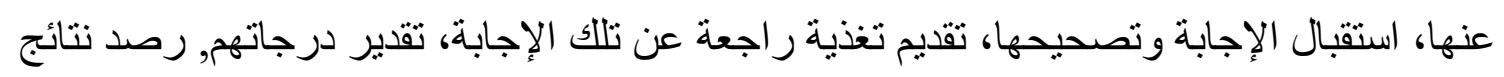

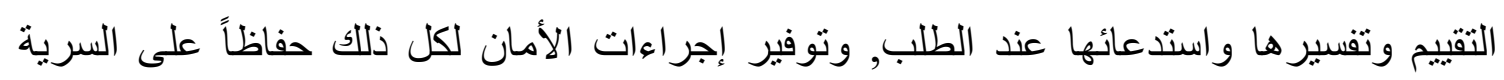

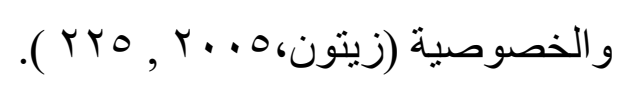

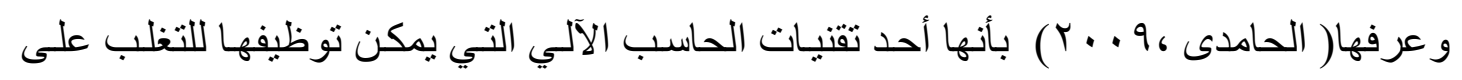

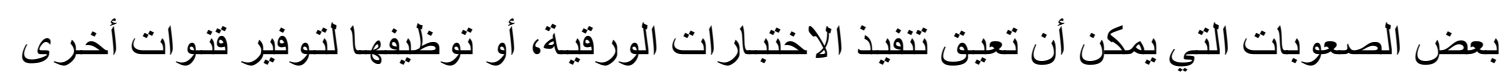

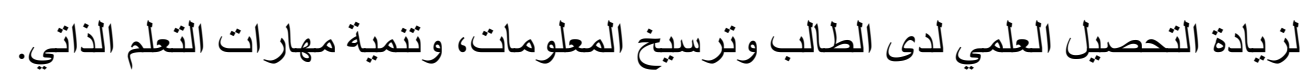

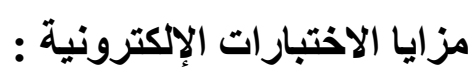

تُعد الاختبارات الإلكترونية بأنواعها الدختلفة من أهم أنثكال التقويم التي يمكن من خلالها

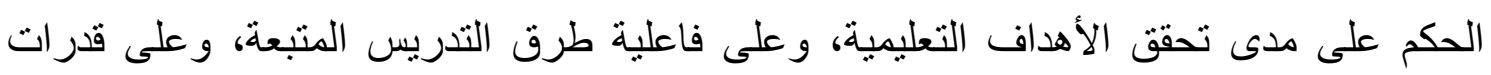
و استعدادات المتعلم للتعليم، وكذلك على فاعلية المو اد التعليمية المستخدمة في عملية التعليه.

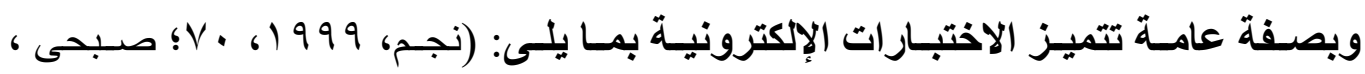

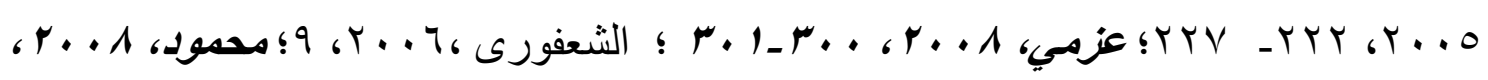




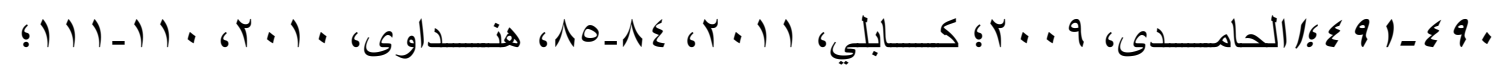
:(Basu,et.al.,2007,1850-1853.

ا ـ توفير أنواع جديدة من الأسئلة تشمل الوسائط المتعددة مثل:الصور، والرسوم، والفيديو، و الصوت، التي تمكن من قياس مهار ات و معارف قد يصعب قياسها عن طريق اختبار ات الورقة و القلم. ץ. التفاعلية: تعني تجاوب الطالب مع بيئة الاختبارات الإلكترونية من خلال استجابة الطالب؛ مثل:الضغط على أحد مفاتيح لوحة المفاتيح, أو كتابة نص، أوتحديد مكان معين, وغير ها من الاستجابات الإلكترونية الأخرى. r. توفير تغذية راجعة وتعزيز فوري وبأثكال عديدة لاستجابات المتعلمين, ويمكن أن تنتوع التغذية الر اجعة لتشمل: الدرجة النهائية في الاختبار أو التكليفــ نقاط القوة و نقاط الضعف في أداء الطالب - تصحيح الأخطاء - إرشادات لتصحيح الأخطاء . ع. سهولة إعداد الأسئلة وتوفير الوقت و الجهد، ويتضح ذلك من خلال:

- إمكانية إعداد الاختبار ات في دقائق معدودة من خلال الاستعانة ببنوك الأسئلة . - إمكانية إجراء تعديلات في أسئلة الاختبار ات عن طريق الحذف أو الإضافة بسهولة و يسر

$$
\text { في زمن محدود للغاية . }
$$

- يمكن إعداد صور متكافئة من الاختبار الواحد بسهولة و يسر. - - إمكانية توليد أنو اع متعددة من الأسئلة. ○. أقل تكلفة من الاختبارت التقليدية (اختبار الورقة والقلم), حيث توفر تكاليف الطباعة و والتخزين. ج. المرونة في تقديم الاختبارات داخل القاعات الدراسية الإلكترونية, أو من بعد باستخدام الشبكات .

V. تسليم الاختبار: ويعني إمكانية تسليم الاختبار ات سواء تم ذلك بشكل تز امني أو غير تز امني لمختلف الطلاب، مع إمكانية تطبيقها في وقت واحد، أو أوقات مختلفة لمجموعة كبيرة من الأفر اد وفي أماكن مختلفة. 
^. سهولة تصحيح ورصد درجات الطلاب و الاحتفاظ بها في سجلات إلكترونبة, مما يوفر بيانات

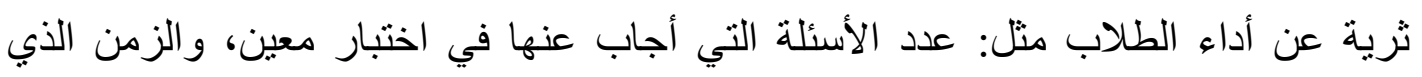
استغرقه في الإجابة عن السؤال الواحد أو الاختبار ككل, و كذلك عدد الأخطاء الثائعة. 9 ـ سهولة استخدام البيانات: حيث إن البيانات الخاصة بتصحيح الاختبارات مخزنة إلكترونياً,

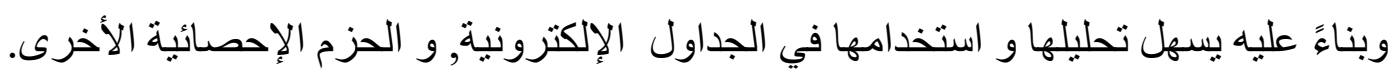

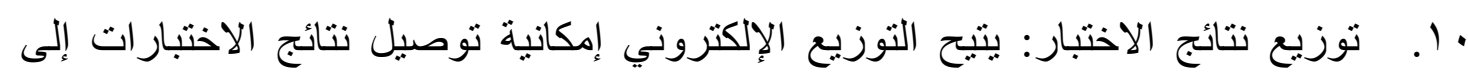

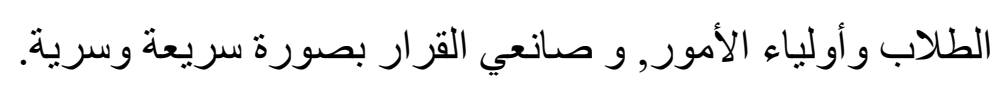

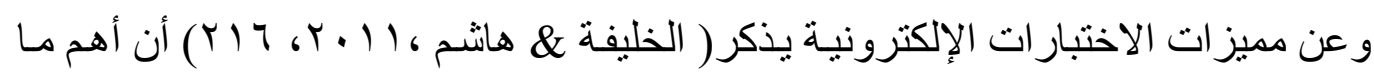

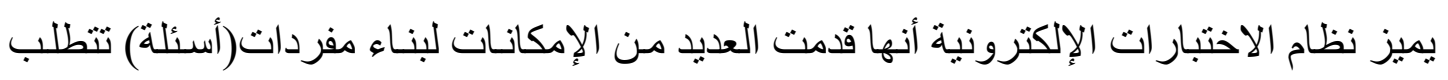

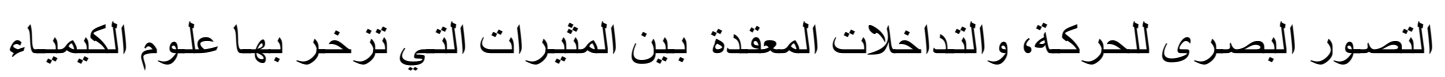

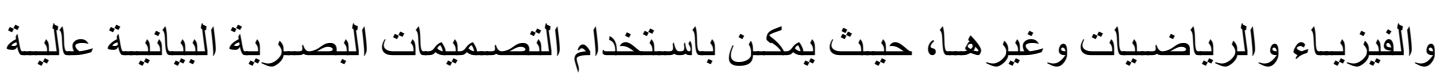

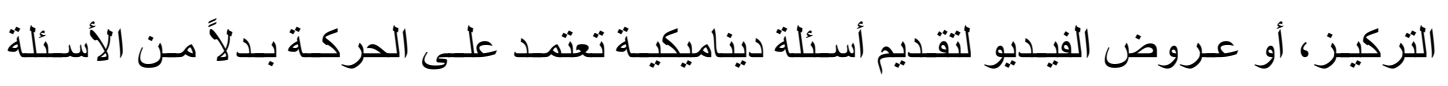

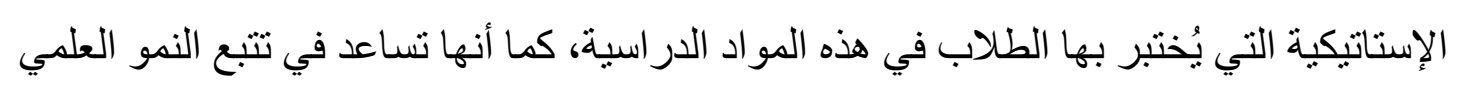

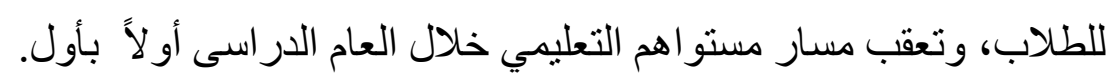

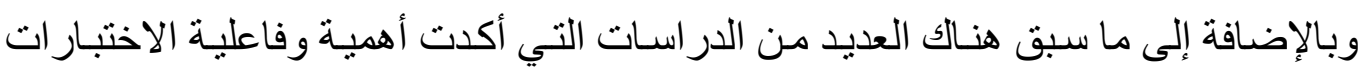

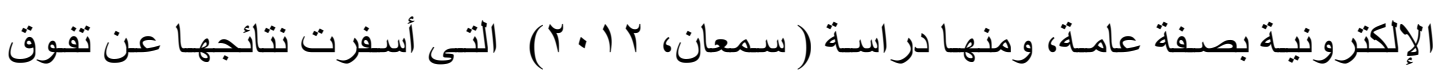

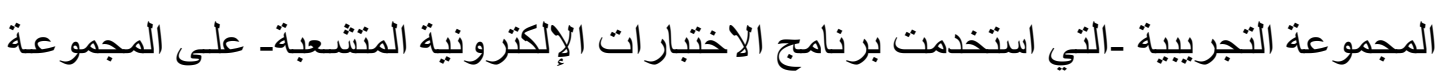

الضابطة في خفض مستوى القلق الرياضي، وارتفاع درجاتهم مقارنة بالمجمو عة الضابطة. أمسا دراسـة (Rosenfield,P., Vicino,S. \& Freda,V.,2000) فقد هدفت إلى تقييم

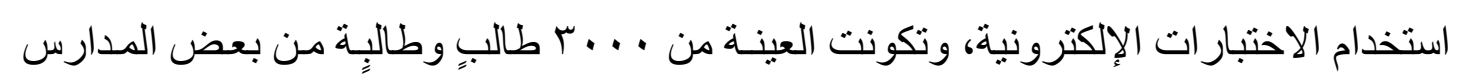

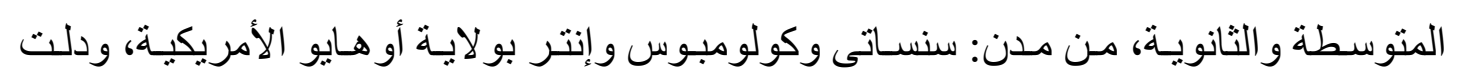
النتائج على:

الإجماع على أهمية استخدام الكمبيوتر في أداء الاختبار. r \% من العينة أيدوا سهولة أداء الاختبار عبر الكمبيوتر.

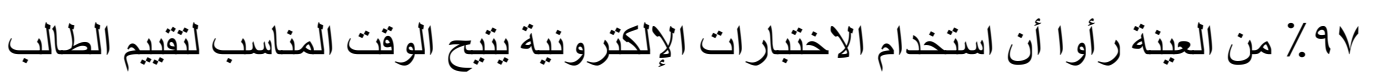


بينما سعت دراسة (Martin,B.\&et al, 2009) إلى تعرف فعالية تطبيق الاختبارات

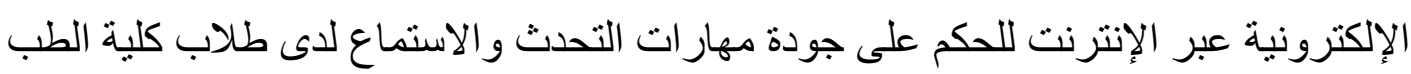
البشري وطب الاسنان، عبر تقديم ملفات صوتية للطلاب، وتلقي استجاباتهم الصوتية على الإنى

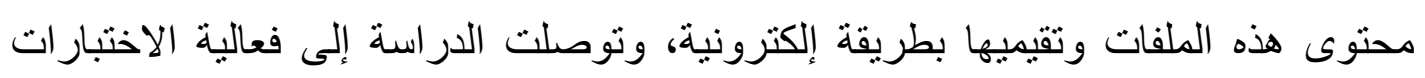

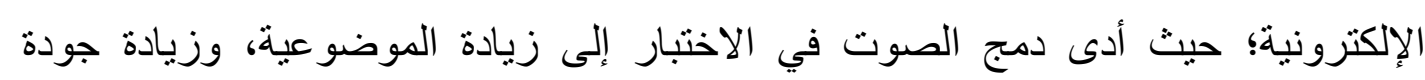
الاختبار، وإلى تقليل الوقت، وانخفاض تكلفة مثل هذه الاختبارات مقارنة بالاختبارات

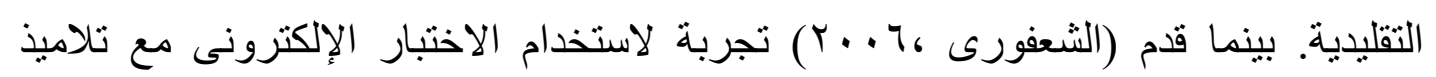

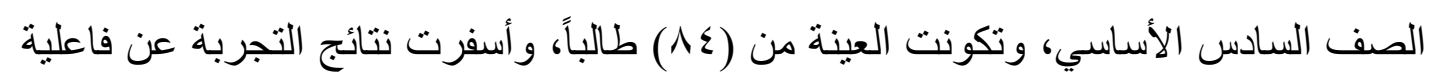

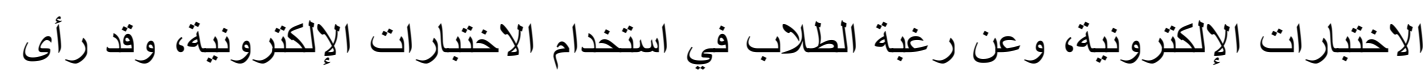

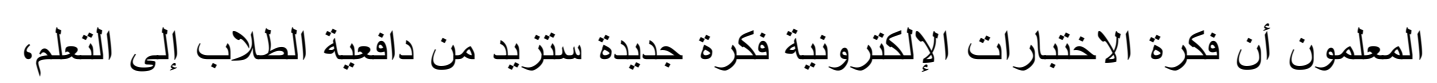

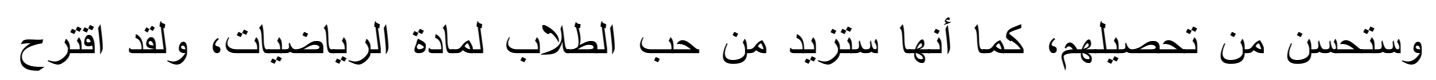
المعلمون ضرورة تطبيق هذا المشروع على مختلف المر احل الدر اسية. من خلال ما سبق يتبين فاعلية الاختبار ات الإلكترونية، وأهميتها بالنسبة للعملية التعليمية،

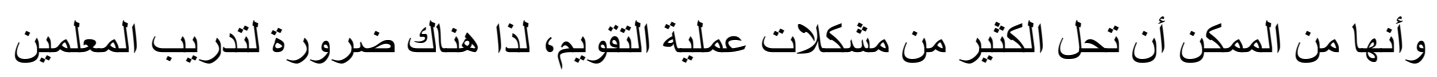
على إنتاجها.

ثالثأ:معايير تصميم وإنتاج الاختبارات الإكترونية:

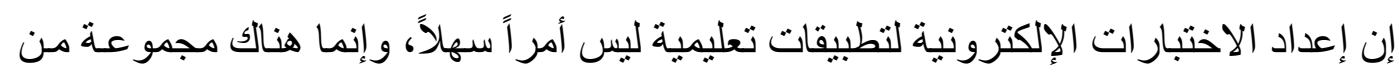

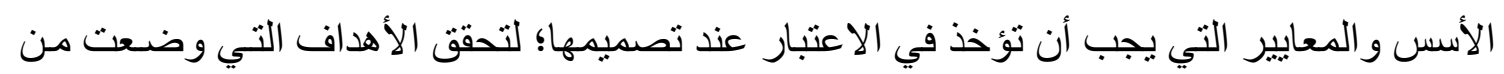

وتمر عملية تصميم الاختبارات الإكترونية بستة مراحل هي: ( إسماعيل، و . . ؟، ـ اء ـ

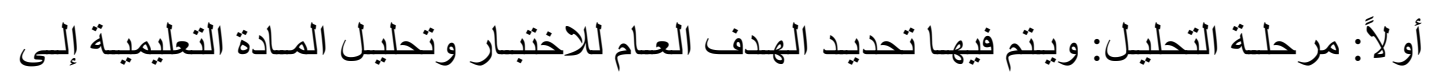
عناصر ها لصياغة محتوى الاختبار. ثانياً: مرحلة التصميم : ويتم فيها إعداد جدول المو اصفات و الوزن النسبة النسبي لأسئلة موضو عات

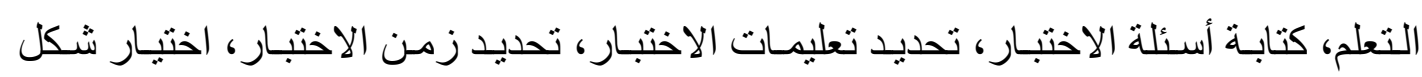
الاختبار وتحديد أنماط الاستجابة، اختيار الوسائط وتصميم سيناريو الاختبار. 
ثالثاً : مرحلة الإنتاج و التطوير : ويتم فيها اختيار برنامج التأليف وتنفيذ تصميم الاختبار وفقاً للمر احل السابقة. رابعاً: مرحلة النشر الإلكتروني والتوزيع: ويتم فيها نشر الاختبار إلكترونياً سواء على أقراص مدمجة أو باستخدام أحد أنظمة إدارة التعلم الإلكتروني.

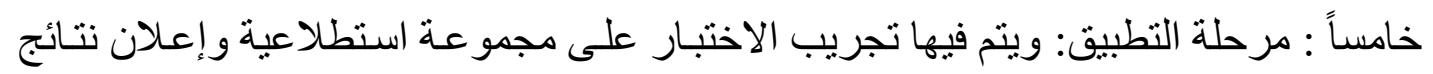
الطلاب إلكترونياً. سادساً:مرحلة التقويم النهائي: ويتم فيها اتخـاذ قر ار صلاحية البيئة الإلكترونيـة للاختبار وفقاً للمعايير البنائية للاختبار ات الإلكترونية.

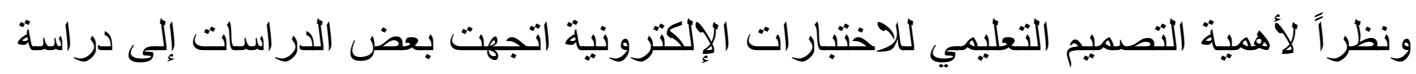

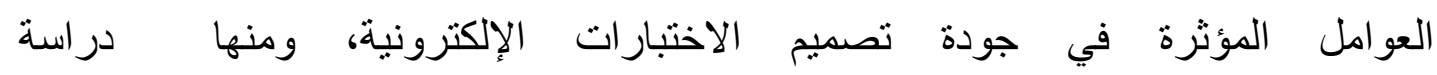
التي فحصت أثر تصميم واجهة شانشات الاختبار ، وكيفية الإجابة على الإنى

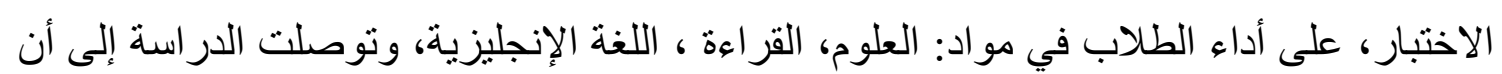
أداء الطلاب في الاختبارات الإلكترونية يتأثز بمدى وضوح واهو واجهات أسئلة الاختبار، وتنسيق

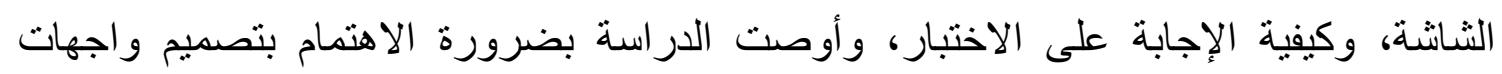

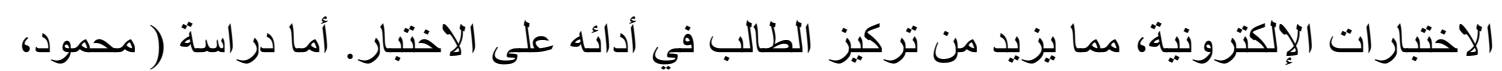

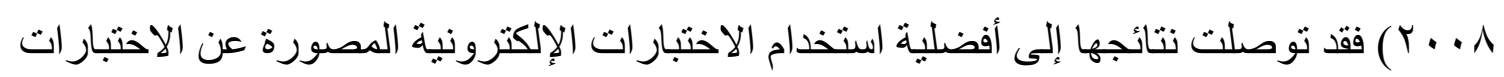
الإلكترونية اللفظية في التحصيل الفوري و المرجأ، لدى عينة من طلاب كلية التربية جامعة طيبة.

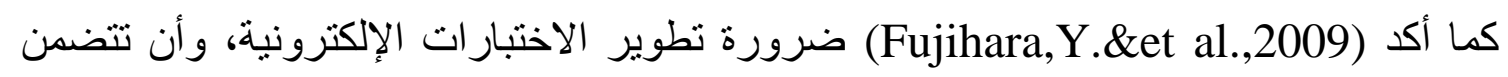

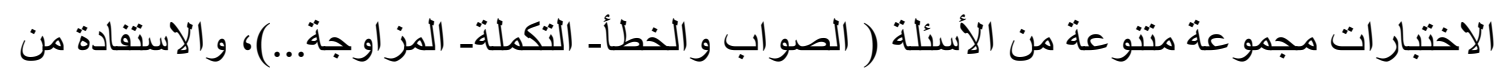
إمكانات الوسائط المتعددة من( نص - صوتـ تغذية راجعة- فيديو) في عرض بنو بنود الاختبار

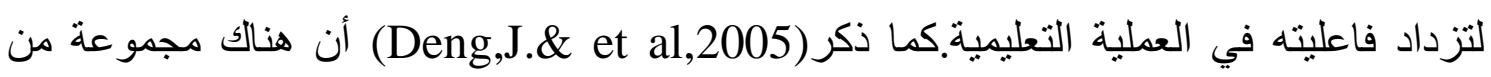
الأسس التي ينبغي مر اعاتها عند تصميم الاختبار ات الإكترونية منها: تنوع الأسئلة، دمج الوسائط

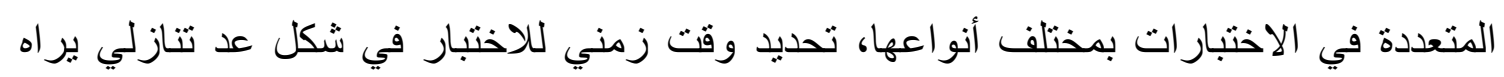
الطالب، إدخال الطالب لبياناته قبل الدخول للاختبار ، طباعة تقرير كامل عند انتهاء الطالب من أداء

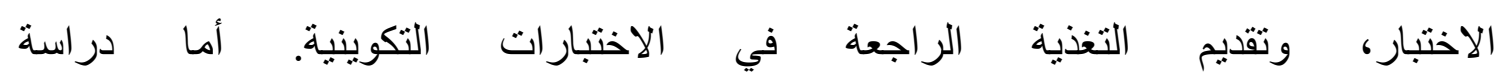
فقد استخدمت الاختبارات الإلكترونية التكوينية الدصحوبة (Nguyen,D.\&Allen,G.,2006) 
بالتغذية الراجعة، وقارنتها بالاختبارات التقليدية، وكثفت نتائجها أن استخدام التغذية الراجعة ساعدت الطلاب على حل مسائل الرياضيات بأسلوب ذكي، كما أدت إلى رفع مستوى الدافعية للتعلم

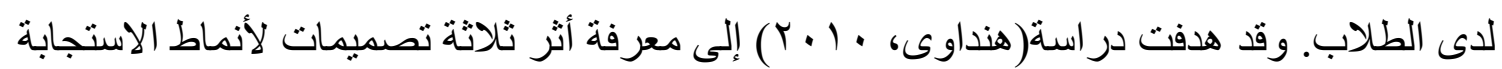

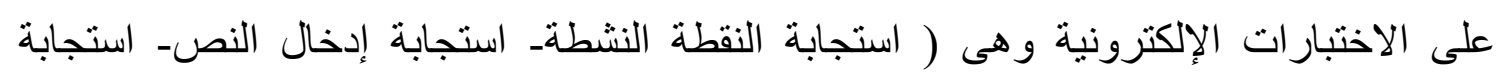

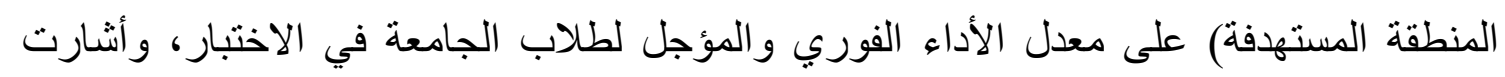

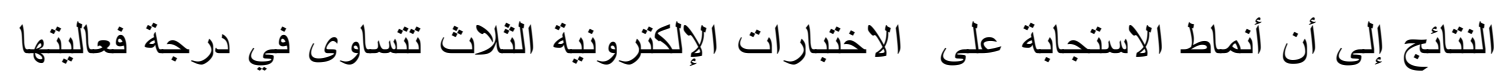

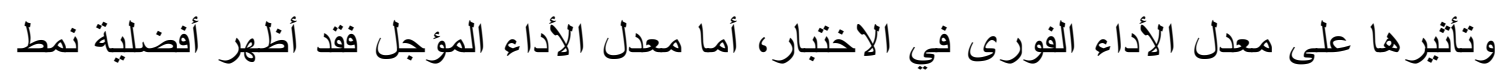
استجابة المنطقة المستهدفة، وتساوي النمطين الآخرين. في ضوء ما سبق يتضح أن هناك مجموعة من الأسس والمعايير الجيدة التي ينبغي النئ

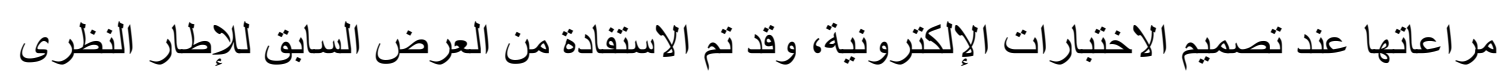

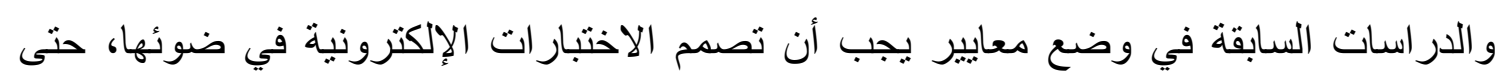
تتحقق الفائدة منها.

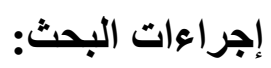

لتحقيق أهداف البحث و التحقق من صحة فروضه، تم اتباع الإجر اءات التالية:

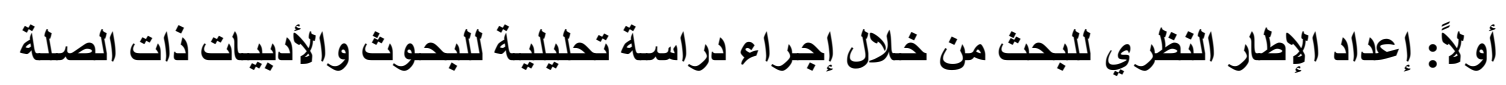
بموضوع ومتغيرات البحث الحالي.

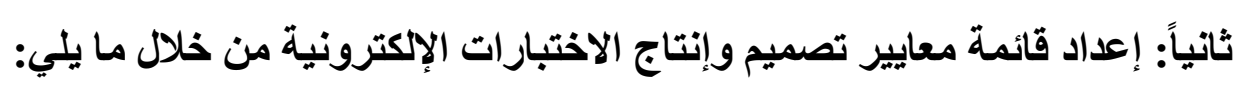

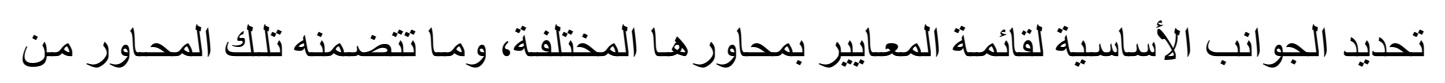
مؤشرات، وذللك من خلال المصادر التالية:

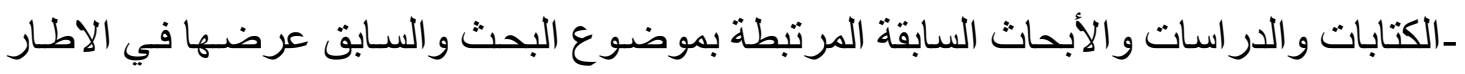
النظري. ـ الأدبيـات التربويـة الخاصـة بإعداد الاختبـار ات التحصـيلية بصـفة عامـة و الإلكترونيـة بصـفة

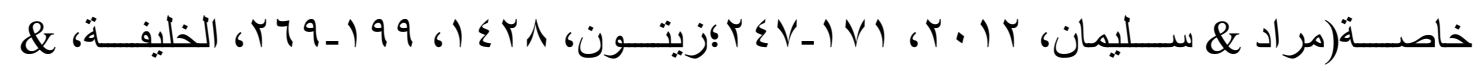

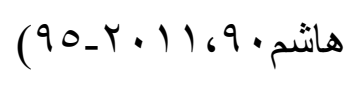

ــشـاهدة العديد من الاختبار ات الإلكترونية، بالإضافة إلى المقابلات التي تم إجر اؤهـا مـع بعض المتخصصين في مجال الحاسب الآلي وتكنولوجيا التعليه. 
(ب) إعداد قائمة المعايير في صورتها الأولية، و التي قد تضمنت (0) معايير ، و ( . . 1 ) مؤشرٍ. (ج) عرض قائمـة المعـايير في صـورتها الأولية على السـادة المحكمين من أسـاتذة المنـاهج وطرق

التدريس وتكنولوجيا التعليم لضبطها وتحديد الأهمية النسبية للمعايير ومؤشر اتها.

(د) وضع الصورة النهائبـة للقائمـة بعد عمل التعديلات اللازمـة في ضـوء أر اء السـادة المحكمين، ومن ثم أصبحت القائمة في صورتها النهائية (1) مكونة من(0) معايير أساسية، و(V0) مؤشراً

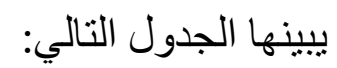

\section{(1) (1)}

\begin{tabular}{|c|c|c|}
\hline المؤشرا & معاييز تصميم وإنتاج الاختبارات & r \\
\hline ro & 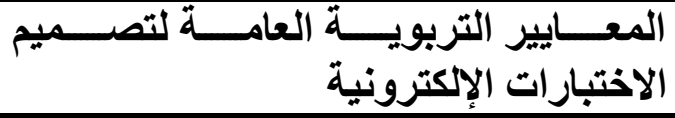 & المعيار (1) \\
\hline 19 & الإكتروني معـايير صـياغة أســـلة الاختبـار & المعيار (ץ) \\
\hline rr & 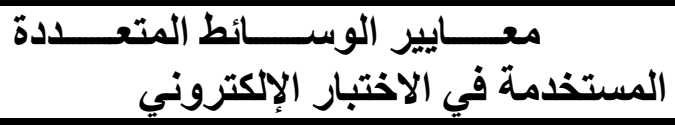 & المعيار( ب) \\
\hline 7 & الالكتروني معـاييز تصـميم شاشـات الاختبـار & المعيار (ع) \\
\hline$r$ & في الاختبار الكترونيز التغذيـة الراجعـة المتضـنـة & المعيار (0) \\
\hline & Vo & الإجمعالي \\
\hline
\end{tabular}

الصورة النهائية لقائمة معايير تصميم وإنتاج الاختبارات الإكترونية

وبذلك تم الإجابة عن السؤال الأول من أسئلة البحث.

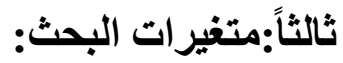

اشتمل البحث على المتغير ات التالية:

أولا: المتغير المستقل: البرنامج القائم على بعض أدوات الويب · , r .

ثانيا: المتغيرات التابعة وهي: 


$$
\begin{aligned}
& \text { • الجو انب المعرفية لمهار ات تصميم و إنتاج الاختبار ات الإكترونية. } \\
& \text { • الجو انب الأدائية لمهار ات تصميم و إنتاج الاختبار ات الإلكترونية. } \\
& \text { رابعاً:مواد المعالجة التجريبية وأدوات البحث: }
\end{aligned}
$$

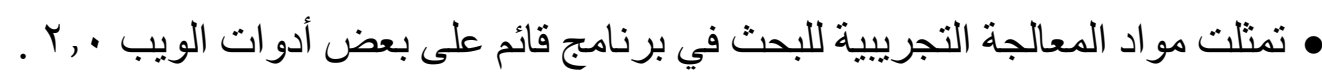

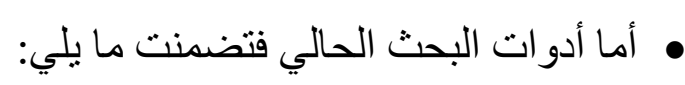

ـ قائمة بالمعايير الجيدة اللازمة لتصميم و إنتاج الاختبار ات الإلكترونية .

$$
\text { ـ قائمة بمهار ات تصميم و إنتاج الاختبار ات الإلكترونية. }
$$

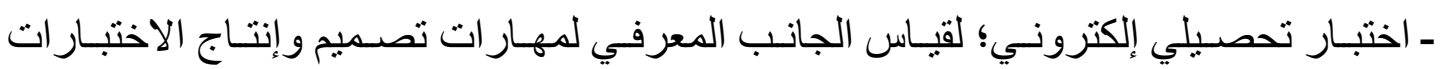

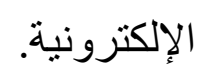

ـ قائمة ملاحظة؛ لقياس الجانب الأدائي لمهار ات تصميم و إنتاج الاختبار ات الإلكترونية. - بطاقة تقييم جودة تصميم و إنتاج الاختبار ات الإلكترونية .

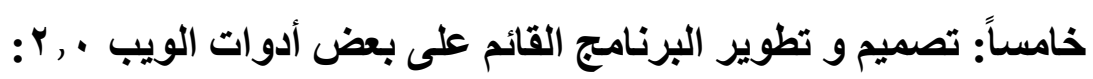

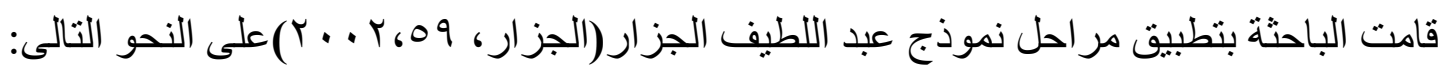

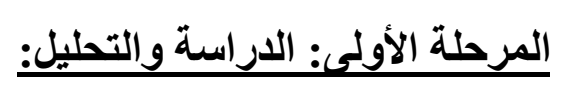

أـ تحديد خصـائص المتعلمين: هن طالبات كلية التربيـة بـالزلفي( تخصصـات علميـة مختلفة)

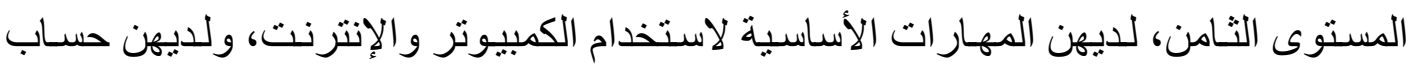

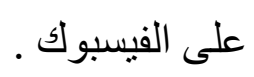

بـ تحديد الحاجة التعليمية: تمثلت الحاجة التعليمية لهذا البرنامج في حاجة طالبـات كلية التربية بـالزلفي إلى المعـارف و المهار ات التي تتــي للديهن مهار ات تصـميم و إنتـاج الاختبـار ات الالكترونية؛ وذلك في ظل التوجهات العالمية، و المحلية نحو توظيف التعلم الإلكتروني في لهي

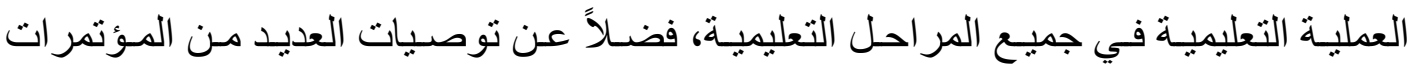

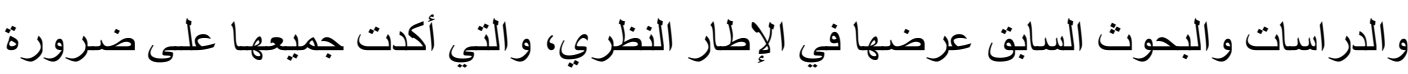
تنمية تللك المهارات. وبناءً عليه اشتقتت الباحثة قائمة بمهار ات تصميم و إنتاج الاختبار ات الإلكترونية التي ينبخي تتميتها لدى الطالبـات من خلال تحليل:الأدبيات التربوية، نتائج الدراسـات و البحوث البهات السـابقة 
العربيـة والأجنبيـة ذات الصـلة بمجـال البحث الحسالي، بالإضـافة إلى خبرة الباحثة في مجـال

$$
\text { تصميم الاختبار ات و الاستبانات الإلكترونية. }
$$

ومن خلال القيام بالإجر اءات السابقة تم استخلاص مجمو عة من المهار الإسبات الخاصـة بإنتاج الاختبار ات الإلكترونية، تم تصنيفها إلى مهار ات رئيسة، ومهار ات فرعية، ثم القبام بترتيبها

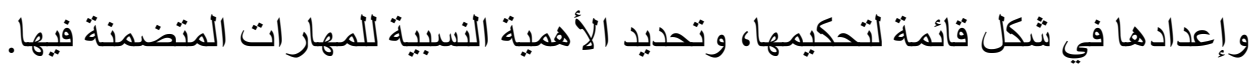

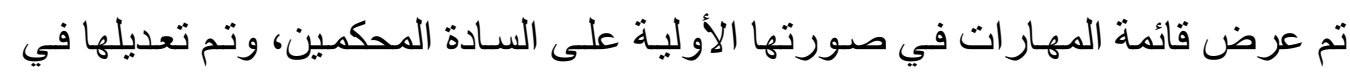

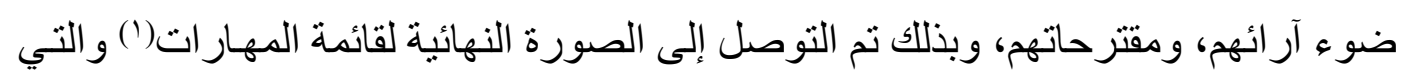

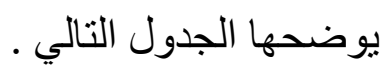

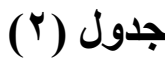

الصورة النهائية لقائمة مهارات إنتاج الاختبارات الإكترونية

\begin{tabular}{|c|c|c|c|}
\hline 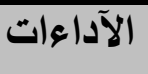 & عدد المهارات & المهار ات الرئيسة & 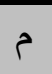 \\
\hline rᄉ & 9 & مهارة إنشاء أسئلة الاختبار الإلكترونى & 1 \\
\hline TY & 0 & مهارة ضبط خصائص الاختبار الإكتروني. & r \\
\hline ro & $\varepsilon$ & مهارة ضبط المظهر الخارجى للاختبار & $r$ \\
\hline 10 & $r$ & مهارة نشر الاختبار الإكتروني & $\varepsilon$ \\
\hline $1 \varepsilon$. & YI & الإجمالي & \\
\hline
\end{tabular}

وبذلك تم الإجابة عن السؤال الثاني من أسئلةً البحث.

ج- دراسة واقع الموارد والمصادر التعليمية ( بيئة التعلم):

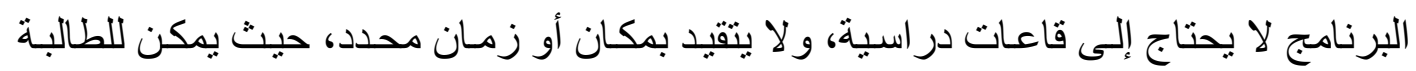

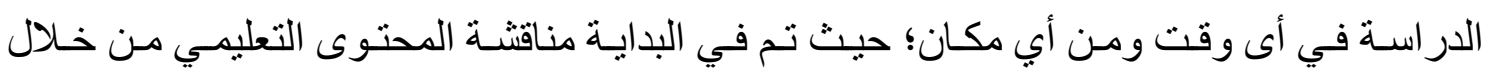
الـGroup على موقع الفيسبوك، ثم توجيه الطالبة إلى المحتوى التعليمي للبرنامج و المقدم من خلال

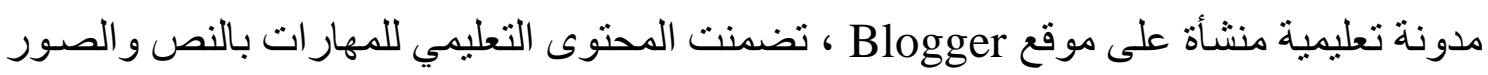
الثابتة التي توضح خطو ات أداء المهارة مصاحبة بالتعليق الكتابى عليها، بالإضافة إلى مقاطع فيديو

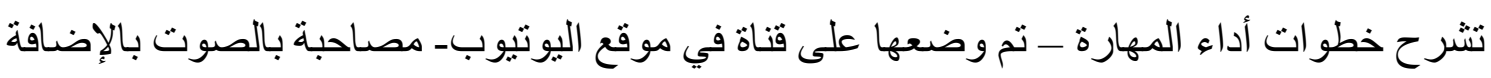
إلى إضافة بعض التأثير ات(نص_أسهم-تكبير -إضاءة) التي توضح المهارة بالتفصيل. 
(أ) - المصادر التي ترجع إليها الطالبات: يمكن للطالبات الرجوع إلى المحتوى التعليمي

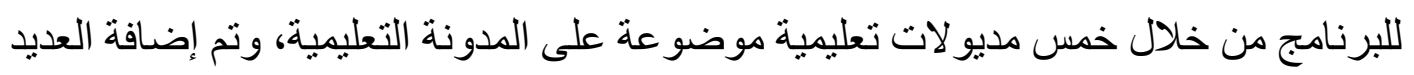
من الرو ابط الخاصة بالمحتوى( ملفات Word، ملفات PowerPoint) بالمدونة بعد تحميلها على موقع Google Drive، بالاضافة إلى دليل استخدام البرنامج ( ورقي وإلكتروني).

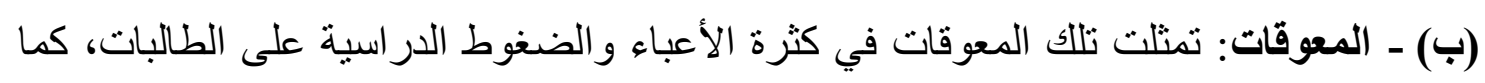
أنهن من تخصصات مختلفة، مما أدى إلى صعوبة عمل لقاءات جماعية بين الطالبات و الباحثة في الكلية، وتم التغلب على ذلك من خلال الـGroup على موقع الفيسبوك، الذي أمكن من خلاله

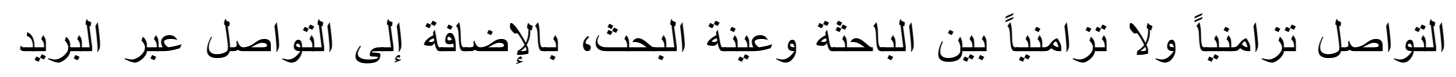

$$
\text { الإلكترونى الذى تم إنشاؤه لهذا الغرض. لزئ. }
$$

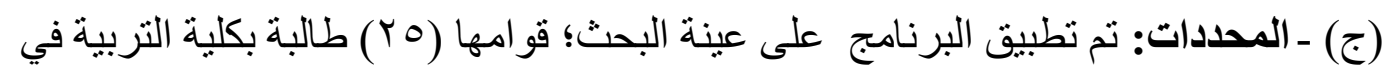

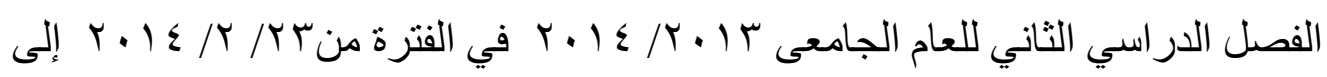

$$
r \cdot 1 \leqslant / r / 1 \text {. }
$$

المرحلة الثانية: مرحلة التصميم:

تضمنت هذه المرحلة القيام بالخطو ات الفرعية التالية:

\section{(1) صياغة الأهداف التعليمية) (1) وترتيب تثتابعها:}

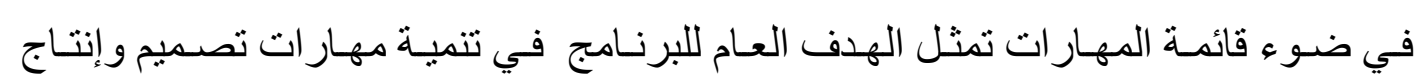

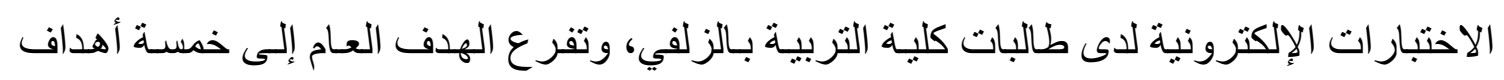

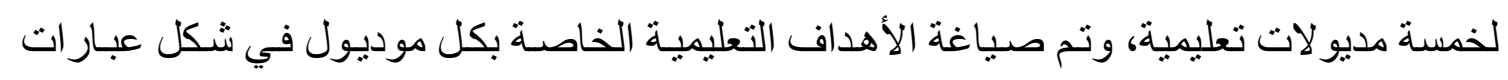
سلوكية تصف سلوك المتعلم.

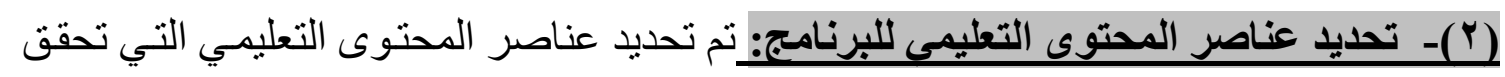

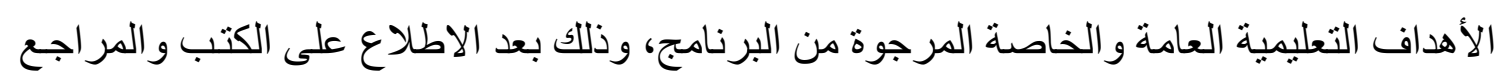

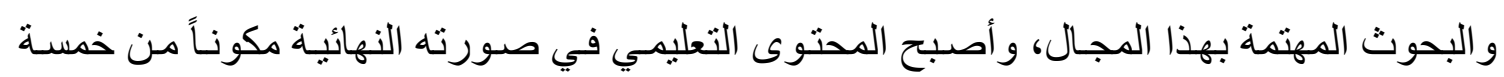

$$
\text { مديو لات تعليمية. }
$$


(ب)- بناء الاختبارات محكية المرجع وأدوات البحث:

في هذه الخطوة تم إعداد أدوات البحث؛ وذللك لتقويم البرنامج وقياس مدى تحقيق الأهداف، وسيتم تناول الخطوات التي مرت بها مر احل إعداد كل أداة من أدو ات القياس في الجزء الخاص بإعداد أدوات القياس المستخدمة في البحث.

\section{(؛)- اختيار خبرات التطلم وطريقة تجميع التلاميذ وأسلوب التعليم للبرنامج:}

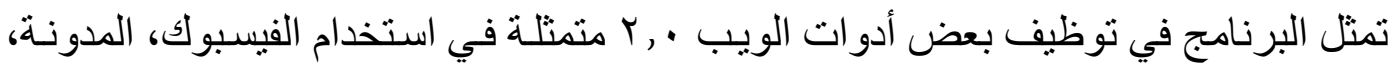

اليوتيوب، ولتحقيق الأهداف التعليمية للبرنامج، تضمن البرنامج الخبرات التالية:

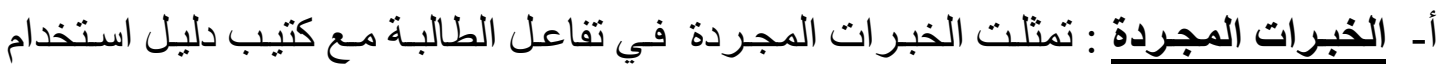

البرنامج الورقي،الذي تضمن الهدف العام للبرنامج، و الأهداف التعليمية الخاصة بكل مديول

تعليمي، مع وصف تفصيلى لكيفية السير في البرنامج، وكيفية أداء الأنشطة.

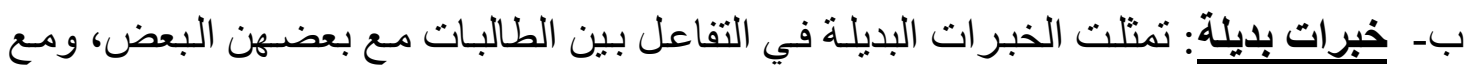
الباحثة من خلال الاتصال اللاتزمنى عبر استخدام الـGroup على موقع الفيسبوك، والبريد

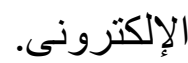

•تفاعل الطالبات مع المحتوى التعليمي للبرنامج؛ و الذي تحقق بقر اءة نص مكتوب، أومشـاهدة صورة ثابتة، تثغيل لقطات الفيديو ؛ لتوضيح المحتوى التعليمي الخاص بالجانب المعرفي

$$
\text { و الأدائي للمهار ات المستهدفة. }
$$

ج- الخبرات المباشـرة : وهى التي تتفاعل فيها الطالبـات بـالأداء و العمل في الواقع، وتمتلت

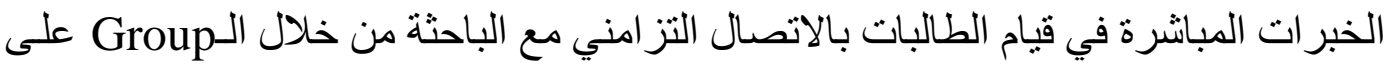
الفيسبوك، والتي من خلالها عرضت الأهداف التعليمية، وعناصر المحتوى التعليمي لكل مديول، ثم إجـر اء مناقثــات حول الموضـو عات الرئيسـة للمحتوى التعليهي، بحيث تقوم

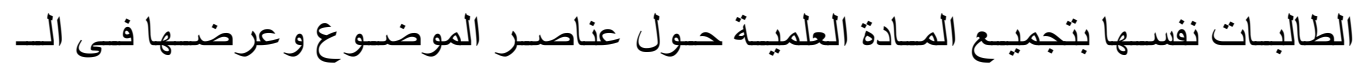
Group العناصر يتم توجيه الطالبات إلى الثكل النهائي الأكثر تنظيماً للمحتوى و الدقدم من خلال

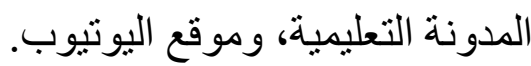




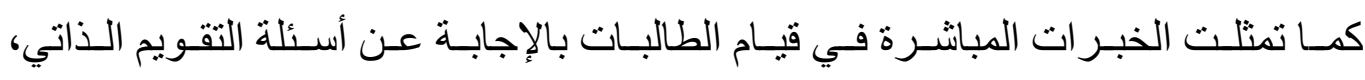

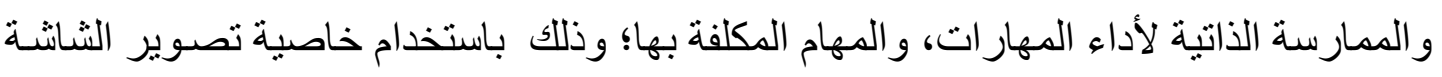
Print Screen ، ووضعها في ملف Word، ثم إرسالها للباحثة لتصديها، و التوجيه إلى الأداء

أما ما يتعلق بطريقة تجميع الطالبات، و أسلوب التعلم فقد اعتمد البرنامج على أسلوب التعلم

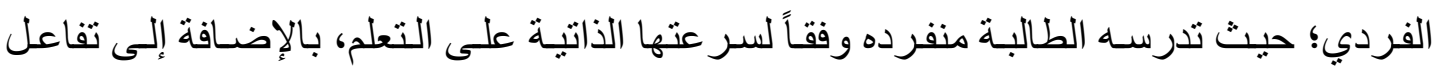

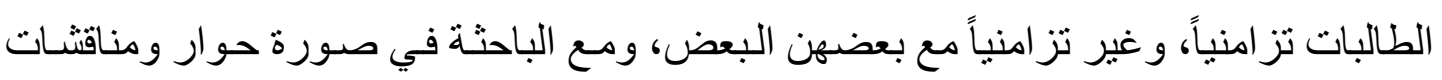

$$
\text { حول الموضو عات عبر الجروب على الفيسبوك. }
$$

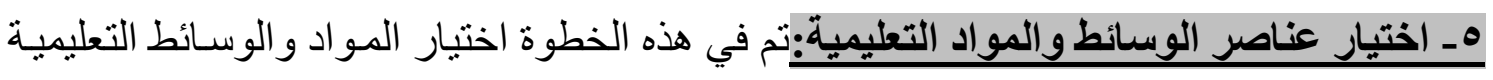

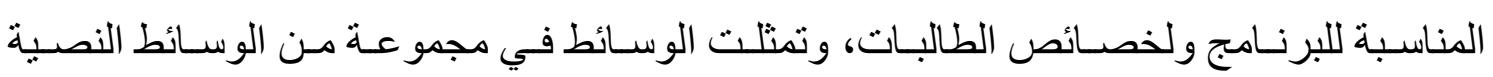
و الصور ولقطات الفيديو. I- تصميم الرسالة التعليمية على عناصر الوسائط : نم صياغة الرسالة التعليمية في ضوء

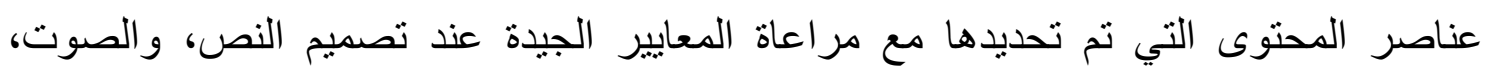

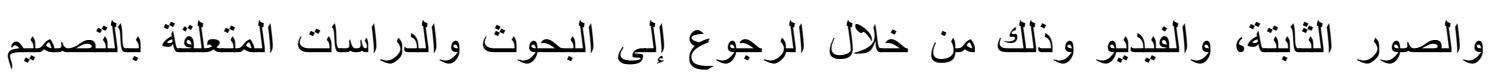

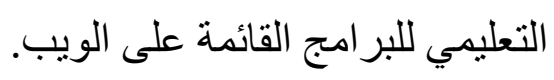

V- تصميم الأحاث التعليمية وعناصر عملية التعليم:حدد نموذج الجزار في هذه الخطوة عدداً من عناصر عملية التعلم التى يجب الاهتمام بها، وفيما يلى توضيح ذلك :

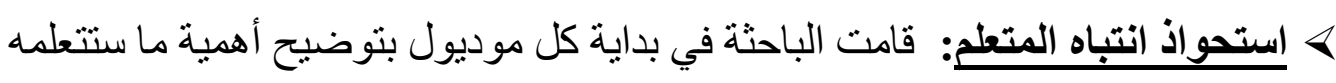

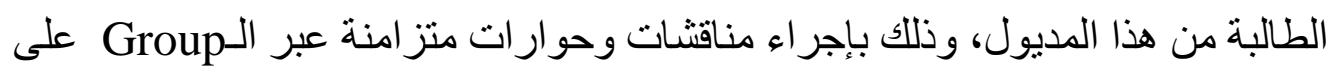

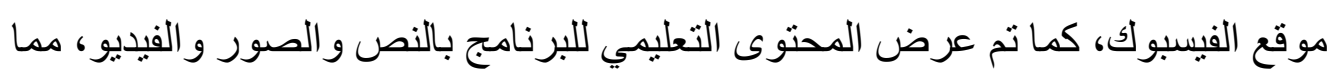
ساعد على الاستحو اذ على انتباه الطالبات. > تعريف الطالبات بأهداف التعلم: راعت الباحثة عند تصميمها للبرنامج أن يحتوى كل

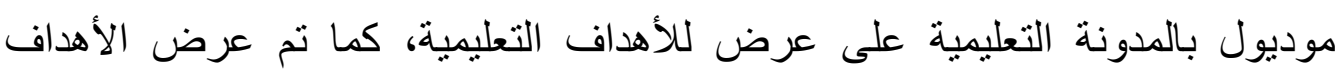
التعليمية عبر موقع الفيسبوك، ودليل استخدام البرنامج في شكليه الورقي و الإلكتروني. > استدعاء التعلم السابق: لا يوجد تعلم سابق خاص بهذه الموديو لات التعليمية، وقد تم مراعاة التسلسل في عرض المحتوى التعليمي؛ فالموديول الثاني مرتبط بالموديول 
الأول، و لا يجوز للطالبة أن تبدأ في دراسته إلا بعد در اسه الموديول الأول وهكذا بالنسبة

$$
\text { لبقية الموديو لات الخمسة. }
$$

> عرض المثيرات للمتعلم :كلما كانت بيئة التعلم غنية بمثير اتها المتكاملة مع بعضها البعض لهض

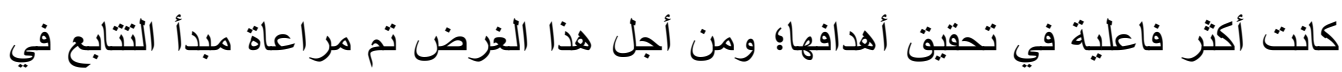
عرض المعلومات على الثشاشة؛ فالمعلومات المتصلة تتبع بعضها البعض؛ حيث يتم البدء بتناول العناصر الرئيسة تتبعها العناصر الثانوية أو الفرعية، كما تم الربط و التكامل

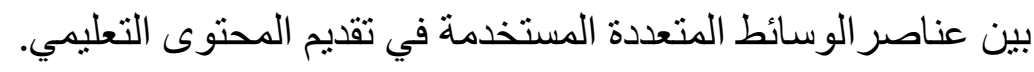

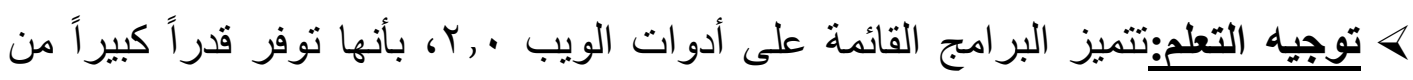

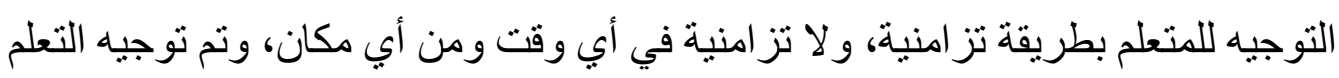

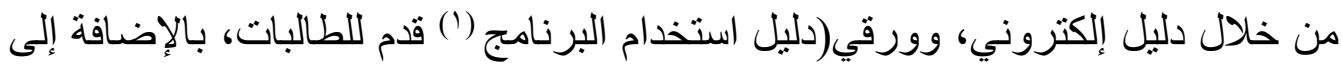
بعض الصور و العبارات الإرشادية الموجودة في كل مديول تعليمي، بالإضافة إلى قيام

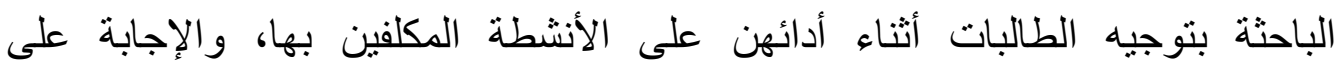

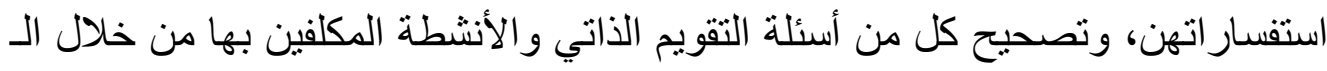

$$
\text { Group }
$$

> تحرير وتنشيط استجابة المتعلم:تم تحرير استجابات الطالبات من خلال أدائهن لأسئلة التقويم الذاتي، والأنشطة التى تتيح لهن ممارسة مهارات تصميم و إنتاج الاختبارات

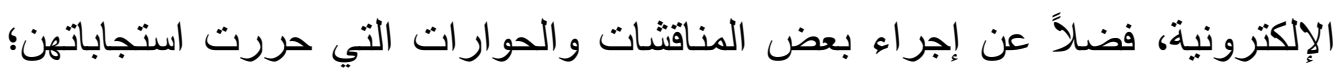
حيث تتصف أدوات الويب . r, بإعطاء المتعلم فرصة بناء المعرفة بنفسه، وتطبيقها،

$$
\text { و اختبار ها، وتعديلها، ومشار كتها مع الآخرين. }
$$

> تقليم التغذية الراجعة:تتمثل التغذية الراجعة في المعلومات التي تحصل عليها الطالبة

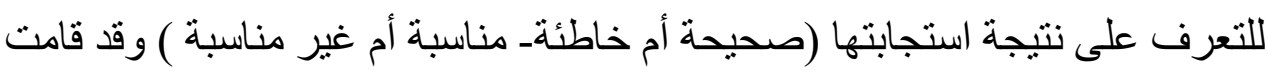
الباحثة بتقيم التخذية الر اجعة الإلكترونية الفورية المباثرة، أو المؤجلة من خلال

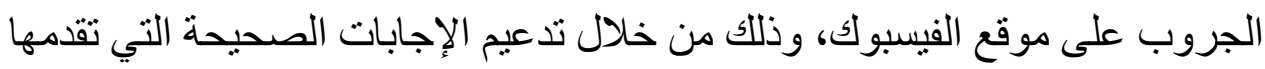

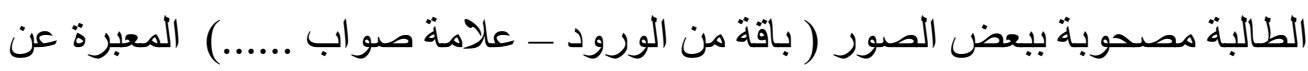


الإجابات الصحيحة، أو بعض عبار ات المدح، و الثنكر، و الثناء، أو معرفه الإجابة الصحيحة إذا كانت استجابتها خاطئة.

× قياس الأداء والتشخيص والعلاج: تضمن البرنامج أدوات لقياس الأداء؛ فلكل مديول

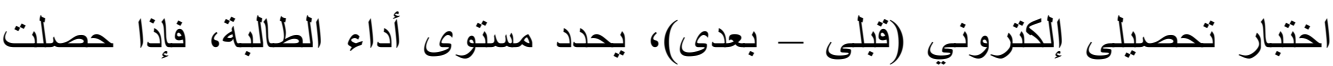
الطالبة على (•9\%) أو أكثر تتنقل إلى دراسة الدديول التالي، أما إذا حصلت على أقل من ذلك فتقوم بدر اسة المديول، و هكذا بالنسبة لدر اسة مديو لات البرنامج، كما تضمن كل مديول أسئلة للتقويم الذاتى، و بعد الانتهاء من دراسة البرنامج ككل، قدم اختبار تحصيلي إلكتروني، وقائمة ملاحظة أداء الطالبات لمهار ات تصميم و إنتاج الاختبار ات الإلكترونية، وبطاقة تقييم جودة الاختبار الإكتروني المعد من قِبل الطالبات.

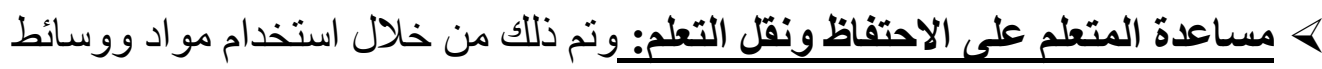
تعليمية متنوعة، كما وفر البرنامج للطالبة فرص الاحتفاظ ونقل التعلم، من خلال ما يقدم لها من أنثطة تعليمية متنو عة.

1ـ تصميم أساليب الإبحار وواجهة التفاعل مع البرنامج : -نم الاعتماد على مدونة تعليمية Blogs كأداة أساسية لعرض المحتوى التعليمي لمهارات تصميم و إنتاج الاختبار ات الإلكترونية، ونم ربطها بموقع الفيسبوك، كما نم إنشاء قناة تعليمية وضع فيها مقاطع الفيديو الخاصة بالمحتوى التعليمي. ـ أما فيما يتعلق بأساليب الإبحار تم الدمج بين التصميم الخطي و التصميم المتفرع؛ ففي التصميم الخطى تكون العلاقة بين صفحات المدونة علاقة خطية بحيث تستطيع الطالبة الانتقال من مديول إلى آخر بسهولة ويسر؛ حيث تضمنت المدونة عدة صفحات، اشتملت الصفحة الرئيسة للمدونـة على دليل استخدام البرنامج، وكل مديول تكون من عدة صفحات، بحيث كل صفحة تعرض عنوان المديول، و المحتوى التعليمي بالنص، و الصور ، والفيديو، وتم ضبط التفاعل داخل الصفحات؛ وذلك بالنقر على عنوان أية صفحة داخل الددونة؛ لتصفح المعلومات بها، واستخدام شريط التمرير لقراءة محتوى الصفحة، أما التصميم المتفرع: فقيه تمنح للطالبة حريـة التجول في الددونة بالسير للأمـام بعد الانتهاء من الجزء المدروس، أو الرجوع للخلف لإعـادة جزء لم تتمكن من فهمهـ أو التتقل العشو ائي داخل المدونة، وذلك من خـلال استخدام الرو ابط داخل صفحات الددونـة، وذلك لتصفح التحنح 
بعض محتويات البرنـامج التي تم إنشـاؤها في صورة ملفات Pdf للانتقال إلى صفحة جديدة، أو

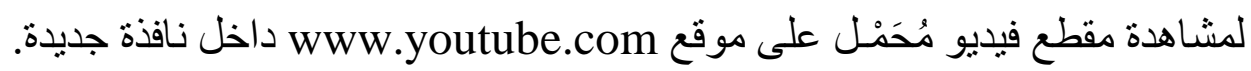

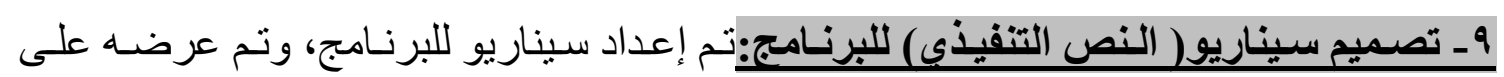

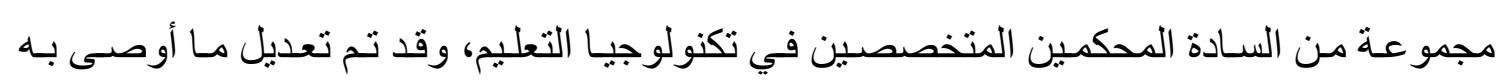
المحكمون، وبذلك أصبح السيناريو (') صالحاً للتنفيذ. . 1ـ تصميم إستراتيجية تنفيذ التعليم:

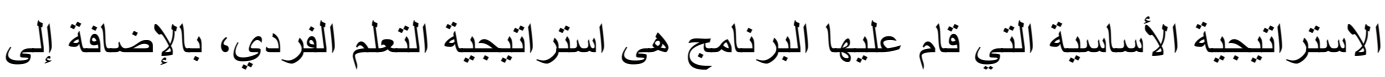

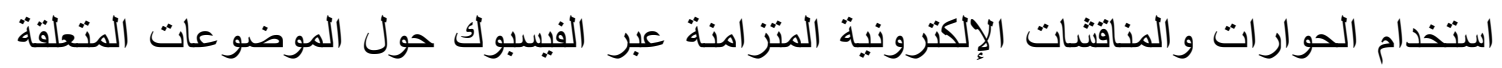
بمفهوم الاختبارات الإلكترونية، مزاياها، عيوبها، مراحل إعداد الاختبارات الإلكترونية، إعداد الإدئه

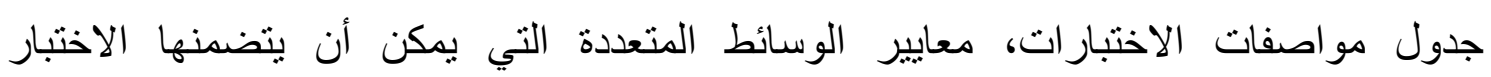

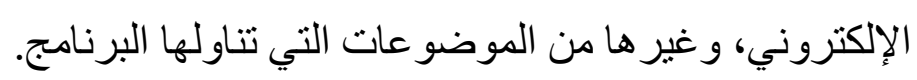

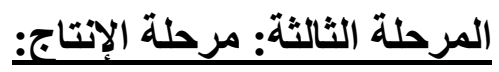

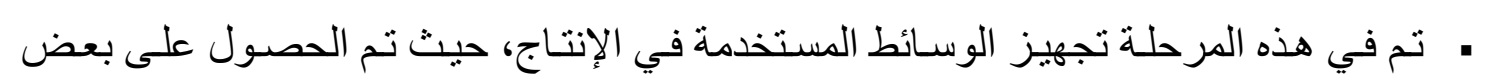

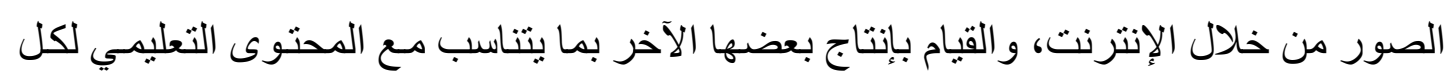

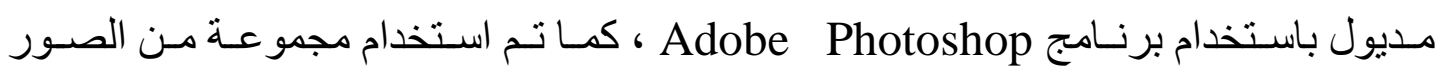

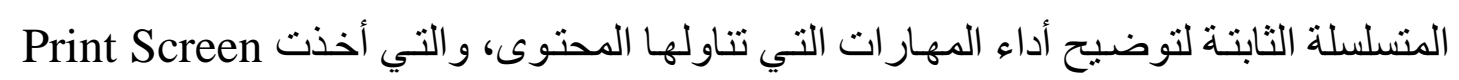
مع التعليق الكتابي عليها. • تم تسجيل لقطات الفيديو الخاصـة بمهار ات إنتاج الاختبار ات الإلكترونية باستخدام برنـامج

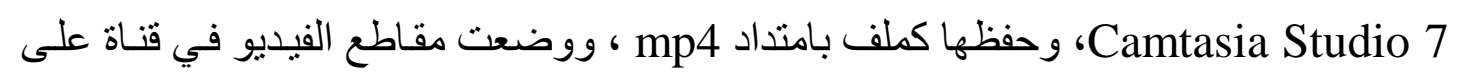
موقع اليوثيوب.

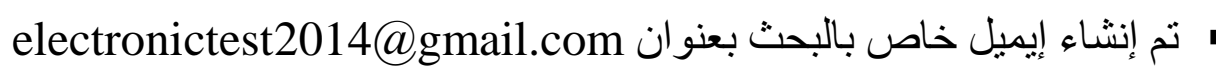

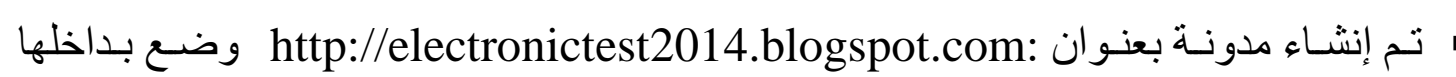
المحتوى التعليمي. • استخدم برنـامج لابرنامج. 


\section{المرحلة الرابعة: مرحلة التقويم للبرنامج: \\ أولاً: التقويم البنائى للبرنامج : التهده:}

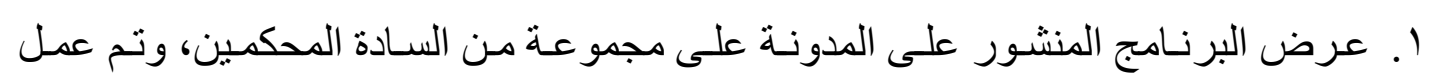
التعديلات اللازمة في ضو اء آر ائهم وتوجيهاتهم، وبذللك أصبح صالحاً للتقويم النهائي. r. تجريب البرنامج على عينة استطلاعية تكونت من ( • () طالبات، وتم أخذ ملاحظاتهم، وتم

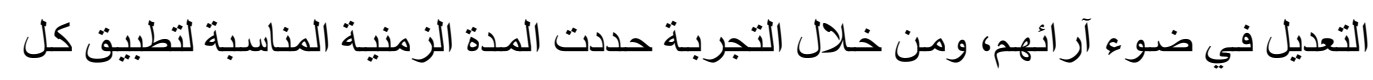
مديول، بالإضافة إلى الزمن المناسب لتطبيق أدوات البحث، وبذللك أصبح البرنامج صـالحاً

$$
\text { للتطبيق النهائي. }
$$

\section{ثانياً: التقويم النهائى للبرنامج :}

استهدفت تلك المرحلة تعرف فاعلية البرنامج في تحقيق أهدافه، وقد تم ذلك عن طريق التطبيق البعدي لأدوات القياس المتمثلة في: الاختبار التحصيلى الإكتروني، قائمة ملاحظة

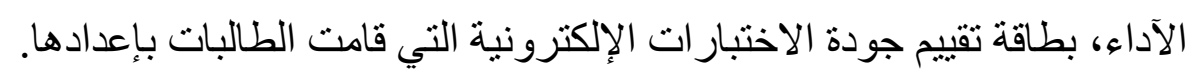
سادساً: إعداد أدوات القياس المستخدمة في البحث: تم إعداد أدوات القياس للبحث الحالي، وفيما يلي توضيح ذللك:

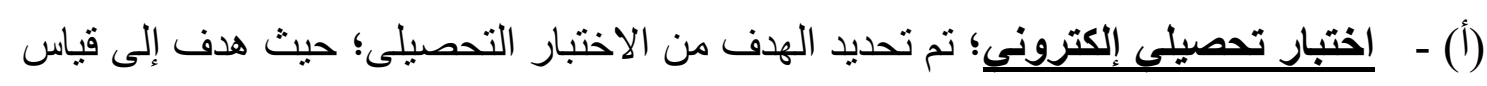
مستوى تحصيل الطالبات- مجموعة البحثـ للجانب المعرفي لمهارات تصميم وانتاج

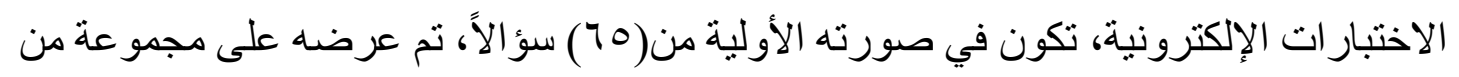
المحكمين، وتعديله وفق آر ائهم ومقترحاتهم، ثم القيام بحساب معامل ثبات الاختبار ( بعد تطبيق الإنيق

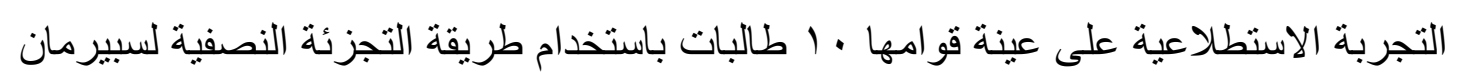

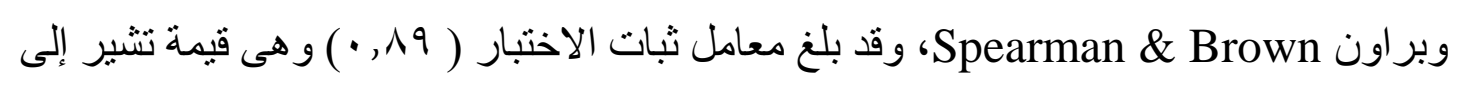

$$
\text { أن الاختبار ثابت إلى حد كبير. }
$$

أما فيما يتعلق بزمن الإجابة عن الاختبار فقد تم حساب متوسط زمن الطالبات(عينة التجربة

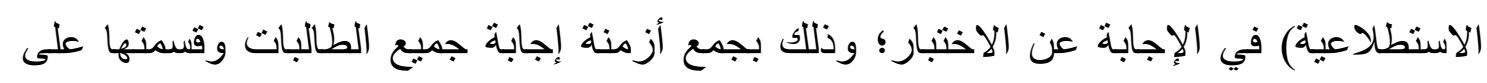

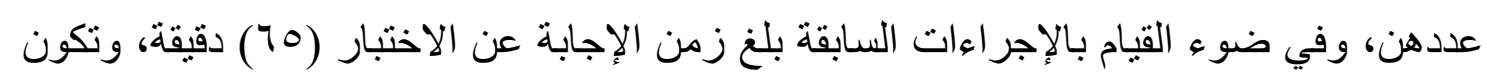


في صورته النهائية من (•T) (؟) سؤالاً تنوعت أسئلته بين أسئلة صواب وخطأ (•r) سؤالاً،

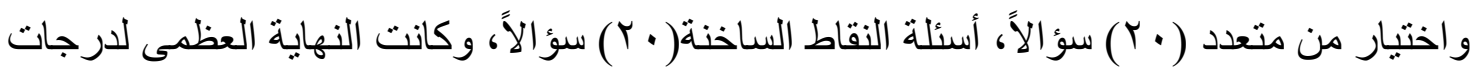
الاختبار( • 7) درجة، وقدُبني الاختبار بحيث تضمن في البداية تعليمات وإرشادات لعينة البحث

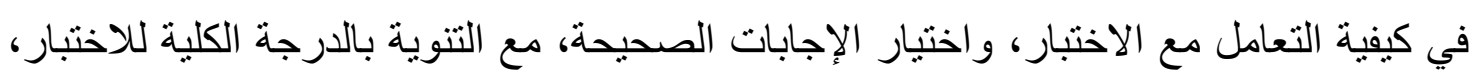
و الزمن المحدد له.

\section{(ب) - إعداد قائمة ملاحظة الأداء:}

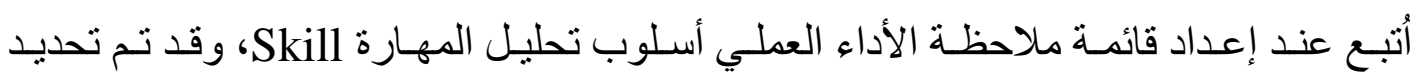

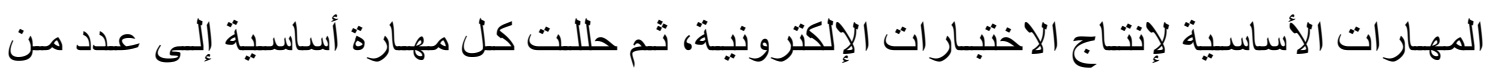

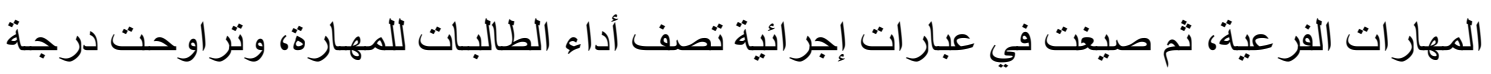

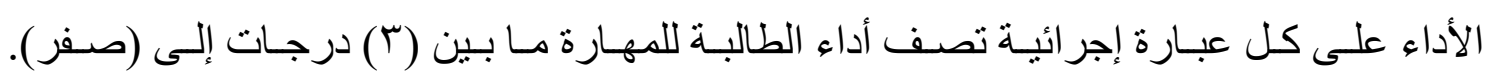
وعرضت بطاقة الملاحظة على مجموعة من السـادة المحكمين، وقد أجمعت الآراء على اكتمال

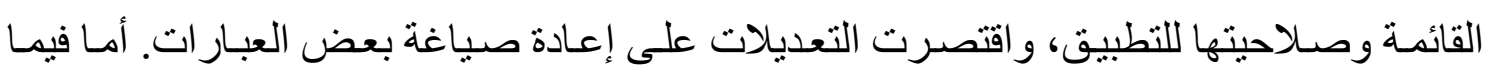

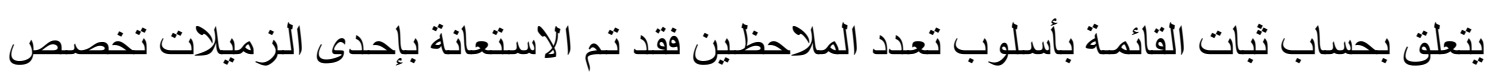

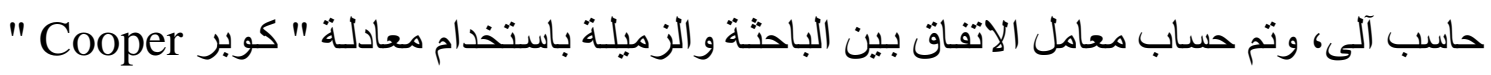

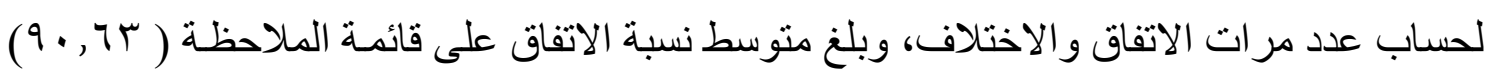

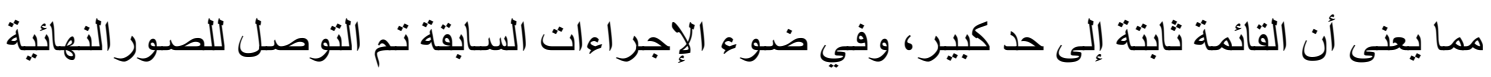

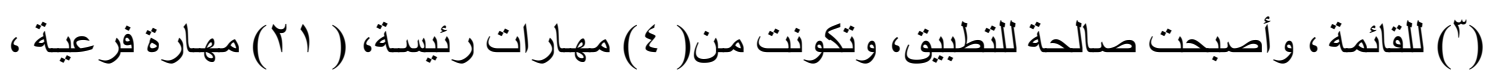

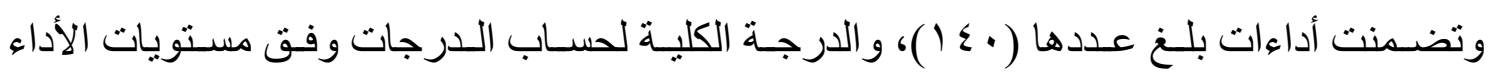

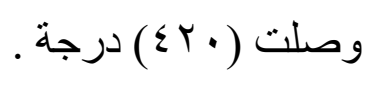

\section{(ج) - إعداد بطاقة تقييم جودة تصميم وإنتاج الاختبارات الإكترونية :}

تم اتباع الإجر اءات التالية لإعداد بطاقة تقييم جودة تصميم و إنتاج الاختبار ات الإلكترونية: 1. . تحديد الهدف من البطاقة و الذي تمثل في قياس جودة تصميم و إنتاج الاختبار ات الإلكترونية

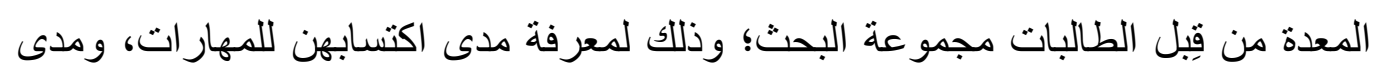
مر اعاتهن لأسس ومعايير جودة تصميم و إنتاج الاختبار ات الإلكترونية. 
r. تحديد محاور البطاقة، وما تشتمل عليه من مؤشرات، وذلك من خلال قائمة المعايير

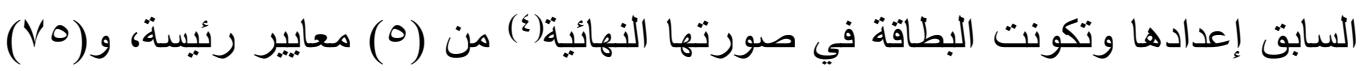
مؤشر آ للأداء.

r. وضع مقياس لمستوى التقييم يتكون من أربعة مستويات نعبر عن مدى نوافر المعيار في

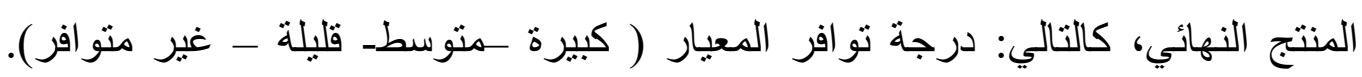

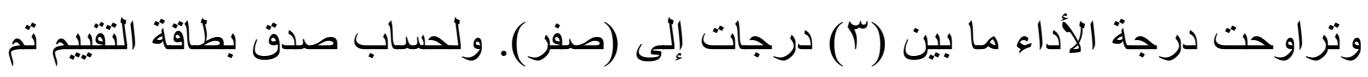

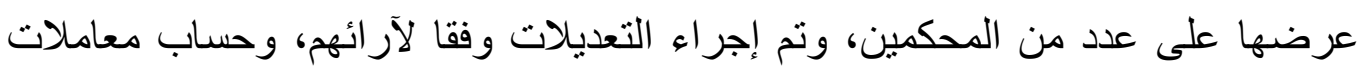

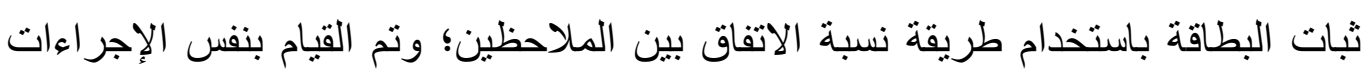

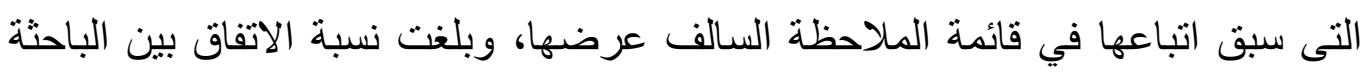
و الزميلة (A^, OV) مما يعني أن البطاقة ثابتة إلى حد كبير، وبعد القيام بالإجر اءات السابقة

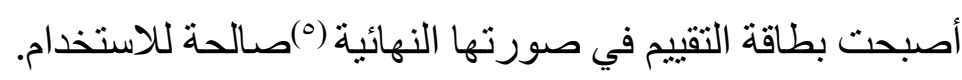
سابعاً: إجراءات تتفيذ التجربة الأساسية للبحث:

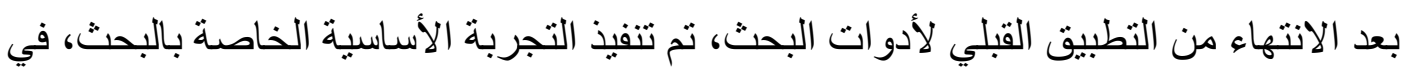

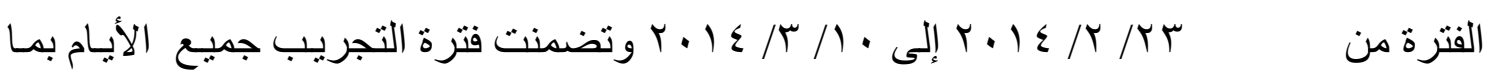

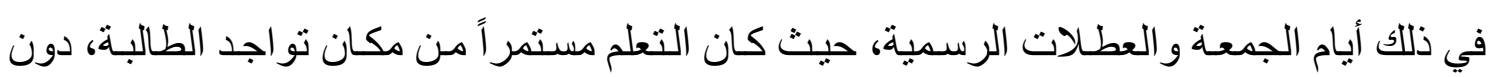
اثشتر اط التو اجد بالكلية، وقد نم تنفيذ التجربة وفق الإجر اءات التالية: ا ـ الإعداد للتجربة: تم الحصول على مو افقة وكيل الكلية للار اسـات العليا بكلية التربيـة بـالزلفي لتطبيق التجربة. r. اختيار مجموعـة البحث، حيث تكونت من (Y0) طالبـة مـن اللاتي تتو افر لديهن المهار ات الأساسية لاستخدام الكمبيوتر والإنترنت، ولديهن حساب على مونى موقع الفيسبوك.

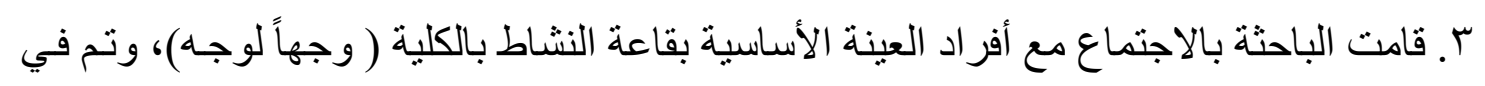

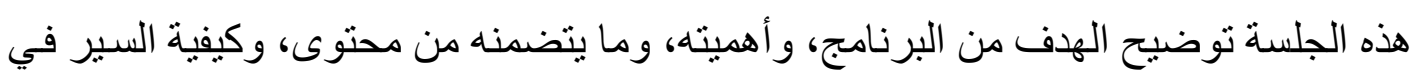

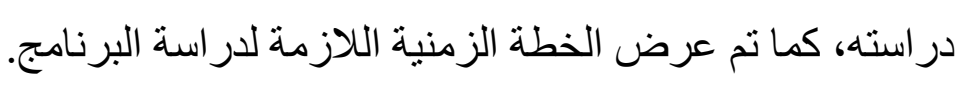
ع ـ تزويد الطالبات بدليل استخدام البرنامج (ورقي /إلكتروني). 
ه. إضـافة الطالبـاتــ مجمو عـة البحثــ من خـلال حسـاباتهم إلى جروب بعنوان: تصميم و إنتاج

$$
\text { الاختبار ات الإلكترونية عبر موقع الفيسبوك. }
$$

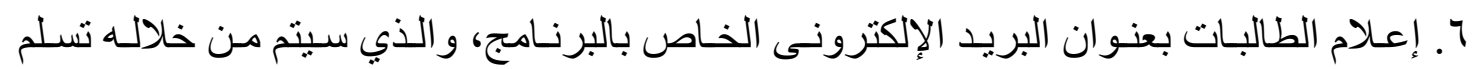

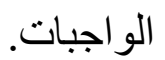

V. إعلام الطالبات من خلال الــroup على الفيسبوك و البريد الإلكترونى عن مو عد بدء تجربـة

البحث.

^. التطبيق القبلي لأدوات البحث ( الاختبار التحصيلي الإلكتروني_قائمـة الملاحظـةــ بطاقـة تقيهم

جودة المنتج).

$$
\text { 9. تطبيث البرنامج على عينة البحث. }
$$

• . . التطبيق البعدي لأدوات البحث، ورصد الدرجات التي حصلت عليهن الطالبات.

ا 1 . . تم رصد النتائج ومعالجتها إحصائيا وتفسيرها.

$$
\text { ا ـ الإحصاء النتائج وتفسيرها: }
$$

الجدول (Y) التالي يوضح الإحصاء الوصفي لمتغيرات البحث؛ حيث تم حساب متوسط

\begin{tabular}{|c|c|c|c|c|}
\hline \multicolumn{2}{|c|}{ القياس البعدي } & \multicolumn{2}{|c|}{ القياس القبلي } & \multirow[b]{2}{*}{ الأداة } \\
\hline الإندر اف & المتوسط & الإنحراف & المتوسط & \\
\hline $1, \wedge \vee 1$ & $\Delta V, \varepsilon$ & $r, I \cdot v$ & $7, \vee 7$ & الاختبار التحصيلح \\
\hline$r, \Lambda \cdot 1$ & $\varepsilon \mid r, \varepsilon \Lambda$ & $\varepsilon, r \varepsilon 1$ & $Y 1, \varepsilon \Lambda$ & بطاقة التقييم \\
\hline$\Lambda, Y \backslash \Lambda$ & $r \cdot q, \cdot \varepsilon$ & $0,1 \wedge 1$ & 19,0 & قائمة الملاحظة \\
\hline
\end{tabular}

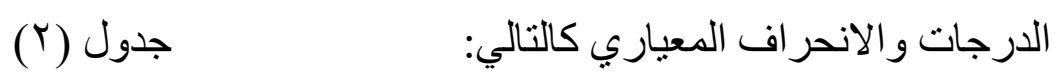

المتوسط والانحراف المعياري للتطبيق القبلي والتطبيق البعدى

للاختبار التحصيلي وبطاقة التقييم ، وقائمة الملاحظة 
r. التحقق من صحة الفروض البحثية:

للتحقق من صحة فروض البحث قامت الباحثة بتطبيق اختبار "ت" (T- test ) للعينات المنر ابطة، وذلك باستخدام حزمة البرامج الإحصائية " SPSS"، وتم التحقق من صحة الفروض كما يلى:

اختبار صحة الفرض الأول: لاختبار صحة الفرض الأول الذي ينص على أنه " يوجد فرق دال إحصائياً عند مستوى (ه . . • )

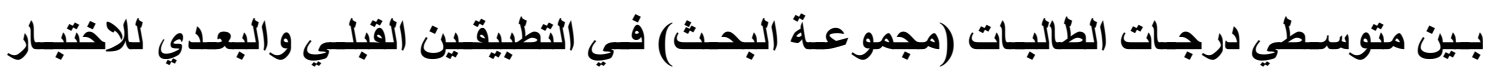

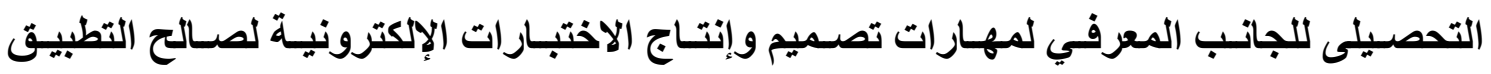

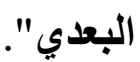
ويوضح الجدول التالي هذه النتائج:

\section{جدول (r)}

قيمة "ت" للعينات المرتبطة لدلالة الفرق بين متوسطي إجمالي درجات الطالبات في التطبيقين القبلي والبعدي للاختبار التحصيلى و قيمة مربع إيتا،حيث عدد العينة(ب0)

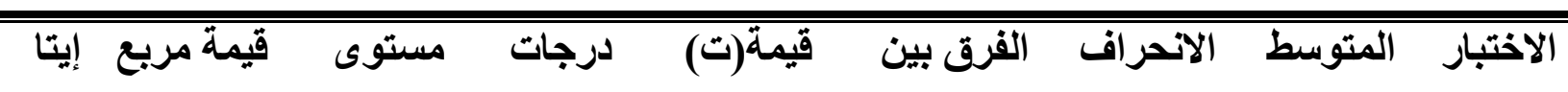

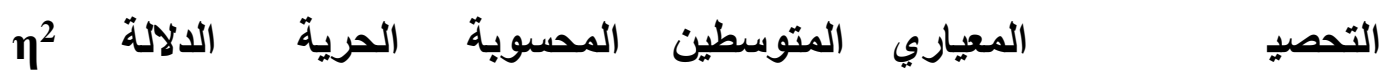

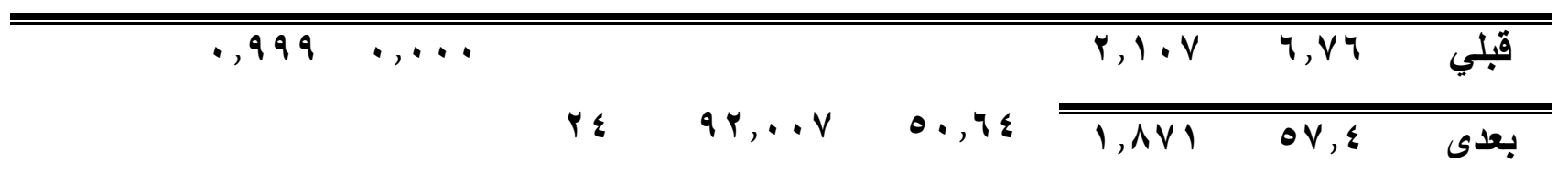

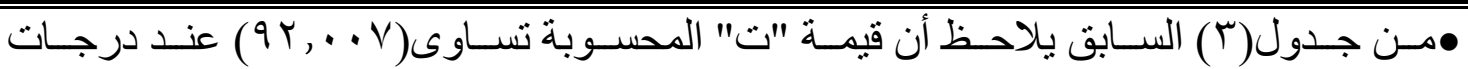
حرية(Y)، و الدلالة المحسوبة كمبيوترياً لها( ( . ., •)، وحيث إن هذه الدلالة المحسوبة أقل من

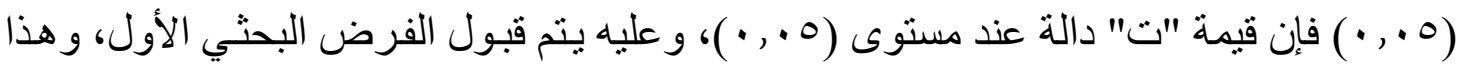

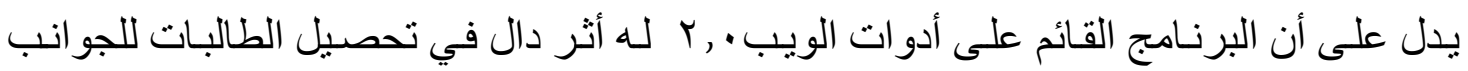
المعرفية لمهار ات تصميم و إنتاج الاختبار ات الإلكترونية. 
•وللتحقق مـن فعاليـة البرنـامج في تحصيل الطالبـات الجانب المعرفي لمهار ات تصميم و إنتاج الاختبار ات الإلكترونية؛ تم حساب حجم الأثر Effect Size ؛ باستخدام مربع إيتا ( وتم حساب قيمة مربع إيتا ( ${ }^{2}$ )، وقد بلغ حجم الأثر في الاختبار التحصيلي ( 999 ، • ) وهو أعلى من القيمـة المحكية (^, • ). و هذا بـل على أن البرنـامج القائم على أدوات الويب • , rحقق حجماً أثر اً كبير اً في تحصسيل الطالبـات للجو انب المعرفيـة لمهار ات تصميم و إنتاج الاختبـار ات الإلكترونية.

هاعلية البرنامج في تحصيل الطالبات الجوانب المعرفية لمهارات تصميم و إنتاج الاختبارات الإلكثرونية: تم حسـاب فاعليـة البرنـامج باسـتخدام معـادلتي (7) نسبـة الفاعليـة " لمـاك جوجيـان" ، ونسبة الكسب المعدلة "لبليك".

\section{(أ) حساب نسبة الكسب المعدلة لبليك:"}

يعرض جدول(ع ) التالي نتائج حساب متوسط نسبة الكسب المعدلة لبليك للتحقق من فاعلية

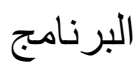

\section{جدول(\&)}

نسبة الكسب المعدلة لـ "بليك" ودلالتها على فاعلية البرنامج في تحصيل الجوانب المعرفية للمهرارات المستثهفة

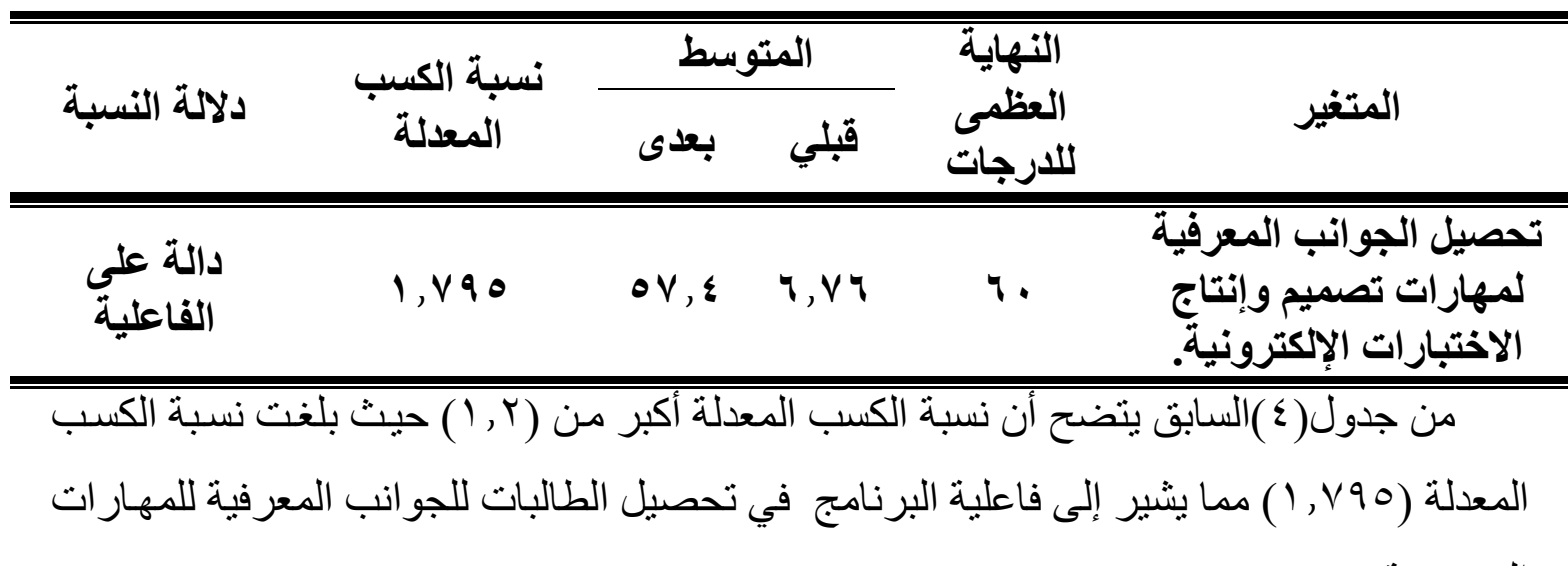

المستهدفة.

(" ) انظر ملحق ( 9 ) الخاص بالمعادلات الرياضية : معادلتي نسبة الفاعلية " لماك جوجيان" ، و نسبة الكسب المعدلة "لبليك". 
(ب) حساب نسبة الفاعلية لـ"ماك جوجيان":

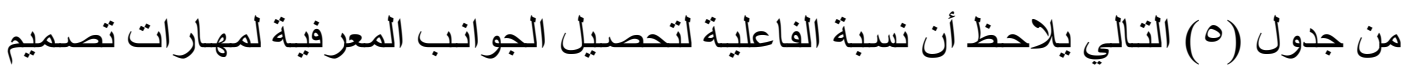

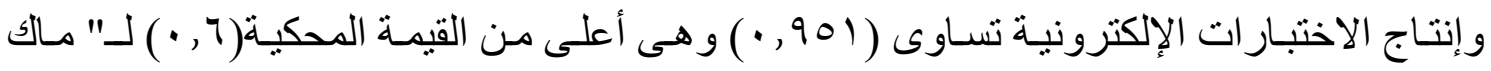
جوجيان ، و هذا يدل على أن البرنامج حقق فاعلية كبيرة في تحصيل الجو انب المعرفية للمهارات

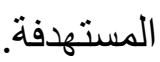

\section{(0) (0)}

متوسط نسبة الفاعلية لـ"ماك جوجيان" لتحيل الجوانب المعرفية لمهارات تصميم وإنتاج

$$
\text { الاختبارات الإكترونية }
$$

\begin{tabular}{|c|c|c|c|}
\hline متوسط نسبة الفابة & الارجة النهائية & متوسط التطبيق & متوسط التطبيق \\
\hline., 901 & 7. & $\Delta V, \varepsilon$ & $7, \vee 7$ \\
\hline
\end{tabular}

لاختبار صحة الفرض الثاني الذي ينص على أنه " يوجد فرق دال إحصائياً عند مستوى (0 . , • ) بين متوسطي درجات الطالبات (مجموعة البحث) في التطبيقين القبلبي والبعدي لقائمسة الملاحظة الخاصـة بالجاتب الآدائسى لمهارات تصميم وإنتاج الاختبارات الإكترونيـة لصالح التطبيق البعدي". تم تطبيق اختبار "ت" (t- test) للعينات المرتبطة، ويعرض جدول (†) نتائج تطبيق اختبار

جدول (7)

قيمة "ت" للعينات المرتبطة لالالة الفرق بين متوسطي إجمالي درجات الطالبات في التطبيقين

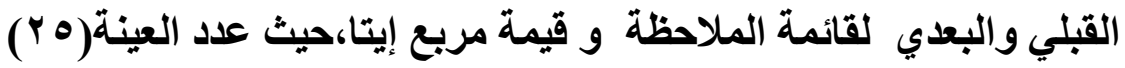

\begin{tabular}{|c|c|c|c|c|c|c|c|}
\hline 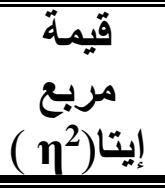 & مستوى الدلالة & الحرية & المحسبوة (ت) & المتوسطين & الالتحراف & المتوسط & الملاحظة \\
\hline \multirow[t]{2}{*}{$\cdot, 999$} & \multirow[b]{2}{*}{$\cdot, \cdots$} & \multirow[b]{2}{*}{$Y \varepsilon$} & \multirow[b]{2}{*}{$r v \cdot, q 0$} & \multirow[b]{2}{*}{ ral } & 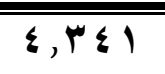 & $\overline{Y I, \leqslant \Lambda}$ & قبلي \\
\hline & & & & & $\overline{P, \Lambda, r}$ & 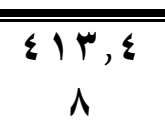 & بعدى \\
\hline
\end{tabular}




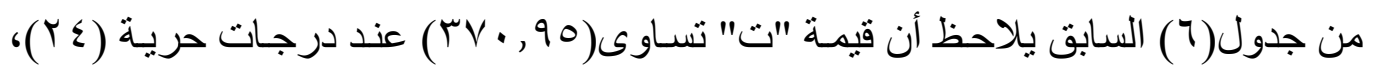

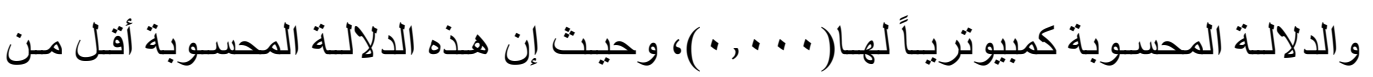
(0 • , • ) فإن قيمة "ت" دالة عند مستوى (0 • , • )، و عليه يتم قبول الفرض البحثي الثاني. بلغت قيمة حجم الأثر (مربع إيتا) في قائمة الملاحظة (999 9 ، • ) و هى قيمة مرتفعة مما يدل على أن البرنامج ذا أثر كبير في تتمية الجانب الأدائي لمهار ات تصميم و إنتاج الاختبار ات الإلكترونية.

囚 فاعلية البرنامج في تنمية الجاتب الأدائى لمهار ات تصميم و إنتاج الاختبار ات الإكترونية:

\section{(أ) حساب نسبة الكسب المعدلة لبليك:"}

من جدول (V) التـالي يتضـح أن نسبة الكسب المعدلة أكبر من (Y ( ) حيث بلغت نسبة الكسب

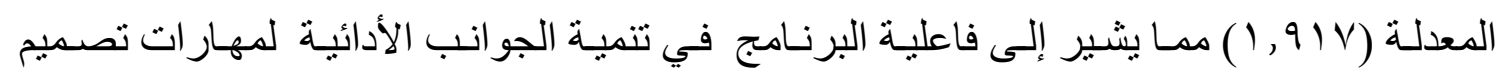
و إنتاج الاختبار ات الإلكترونية.

\section{(V) (1)}

نسبة الكسب المعدلة دـ "بليك" ودلالتها على فاعلية البرنامج في تتمية الجوانب الأدائية للمهارات المستهدفة

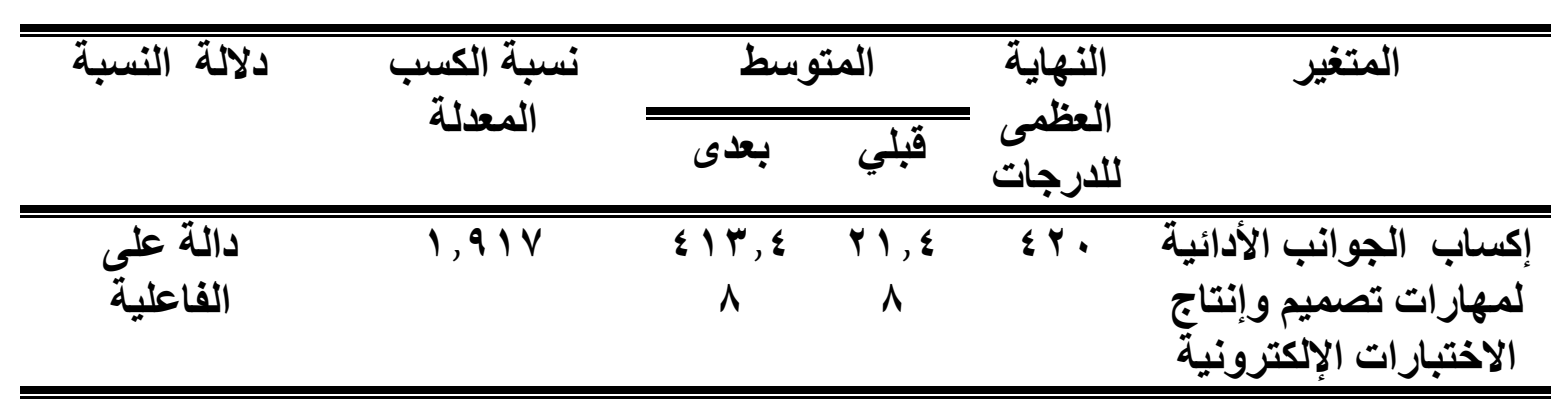

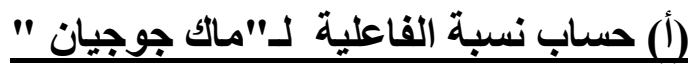

من جدول(^) التالي يلاحظ أن نسبة الفاعلية لتنمية الجو انب الأدائية للمهار ات المستهدفة تساوي(س^و , • ) و هى أعلى من القيمة المحكية(7 , • ) لـ"ماك جوجيان، وهذا بدل على أن البرنامج يحقق فاعلية كبيرة في تنمية الجو انب الأدائية لمهار ات تصميم و إنتاج الاختبار ات الإلكترونية. 


\section{جدول(^)}

متوسط نسبة الفاعلية لـ"ماك جوجيان" لتنمية الجواتب الأدائية للمهارات المستهدفة

\begin{tabular}{|c|c|c|c|}
\hline متوسط نسبة & الارجة النهائية & متوسط التطبيق & متوسط التطبيق \\
\hline$\cdot, q \wedge r$ & $\varepsilon r$. & $\varepsilon 1 r, \varepsilon \wedge$ & $Y 1, \leqslant \Lambda$ \\
\hline
\end{tabular}

\section{اختبار صحة الفرض الثالث:}

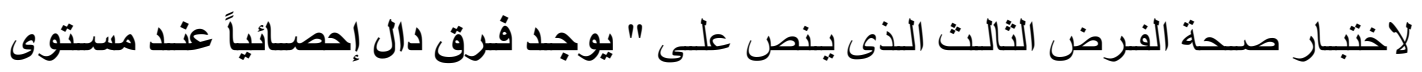
(ه • , • ) بين متوسطي درجات الطالبات (مجموعة البحث) في التطبيقين القبلي والبعدي لبطاقة تقييم جودة الاختبارات الإكترونية المنتجة لصالح التطبيق البعدي".

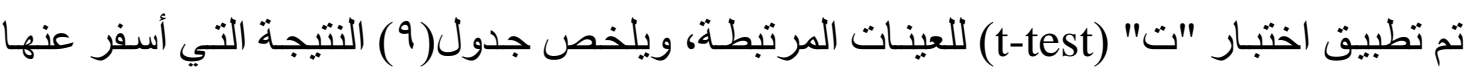
جدول ( ) استخدام هذا الاختبار. قيمة "ت" للعينات المرتبطة لدلالة الفرق بين متوسطي درجات الطالبات في التطبيقين القبلي والبعدي لبطاقة التقييم و قيمة مريع إيتا،حيث عدد العينة(ro)

\begin{tabular}{|c|c|c|c|c|c|c|c|}
\hline $\begin{array}{l}\text { مريع إيتا } \\
\text { ميمة } \\
\left(\eta^{2}\right) \\
\end{array}$ & مستوي الدلاكة & لدرجات & قالمحسوة (ت) & المثرق بين & الالحعراف & المتوسط & التقييم \\
\hline \multirow[t]{2}{*}{ - 999} & \multirow{2}{*}{$\cdot, \cdots$} & \multirow{2}{*}{ \& } & \multirow{2}{*}{$q r,\{r 1$} & \multirow{2}{*}{$1 \wedge 9, \varepsilon$} & $0,1 \wedge 1$ & 19,0 & قبلي \\
\hline & & & & & $\Lambda, M \wedge$ & & بع \\
\hline
\end{tabular}

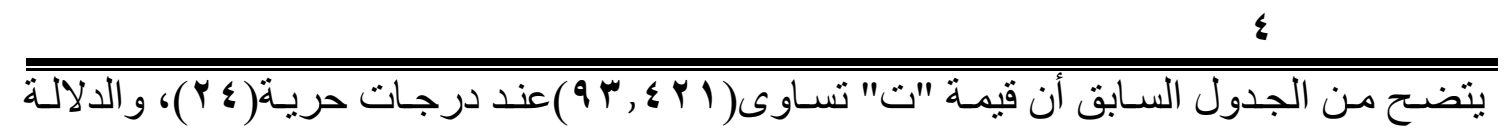

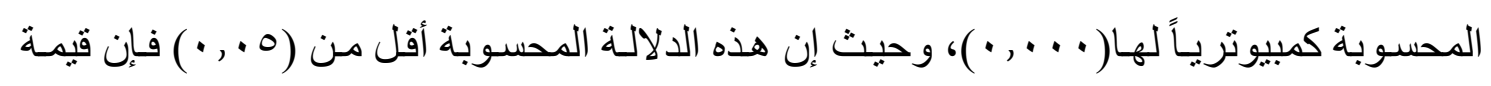

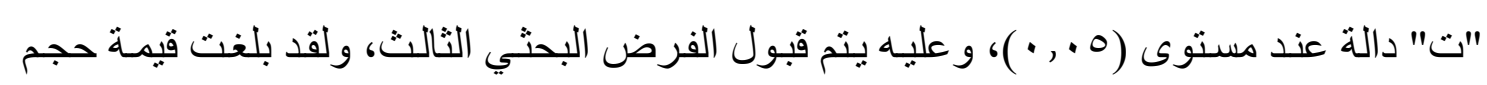

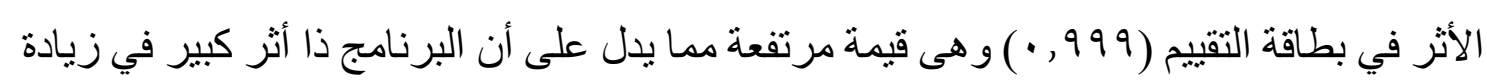
مستوى جودة الاختبار ات الإلكترونية المنتجة من قِبل الطالبات. 


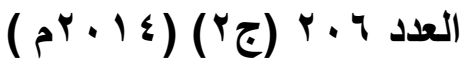
مجلة دراسات في المناهج وطرق التدريس

هاعلية البرنامج في تنمية الجوانب الأدائية لجودة تصميم و إنتاج الاختبارات الإكترونبة) بطاقة تقيبم المنتبج)

\section{(أ) حساب نسبة الكسب المعدلة لبليكة:"}

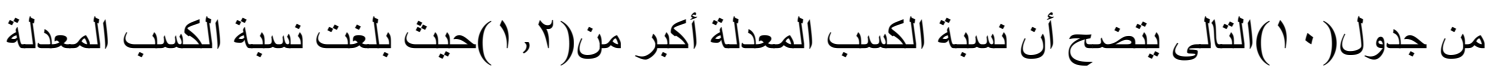

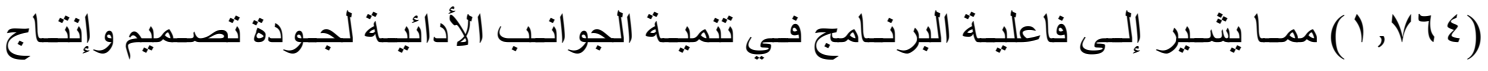
الاختبار ات الإلكترونية.

$$
\text { جدول(·) }
$$

نسبة الكسب المعدلة لـ "بليك" ودلالتها على فاعلية البرنامج في تنمية الجوانب الأدائية لجودة تصميم وإنتاج الاختبار الإلكتروني

\begin{tabular}{|c|c|c|c|c|c|}
\hline \multirow[t]{2}{*}{ دلالة النسبة } & \multirow{2}{*}{ نسبة الكسبة } & \multicolumn{2}{|c|}{ المتوسط } & \multirow{2}{*}{ اللارجهاتية } & \multirow[t]{2}{*}{ المتغير } \\
\hline & & بعدى & قبلي & & \\
\hline دالة على الفاعلية & $1, \vee \vee \varepsilon$ & $\begin{array}{c}r \cdot q, \cdot \\
\varepsilon\end{array}$ & 19,0 & Yro & الأكسابة الجوانية لجودة \\
\hline
\end{tabular}

\section{حساب نسبة الفاعلية لـ"ماك جوجيان}

من جدول(1 (1) التـالى يلاحظ أن نسبة الفاعلية لتنميـة الجو انب الأدائية لجودة تصميم و إنتاج

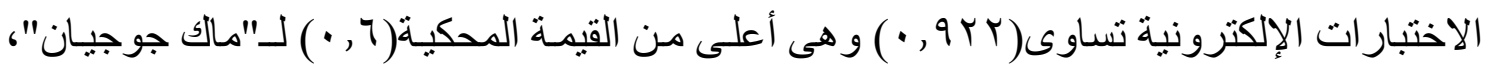
و هذا يدل على أن البرنـامج يحقق فاعليـة كبيرة في تتميـة الجو انب الأدائية لجودة تصميم و إنتاج الاختبار ات الإلكترونية.

$$
\text { جدول(1) (1) }
$$

متوسط نسبة الفاعلية لـ"ماك جوجيان" لتتمية الجوانب الأدائية للمهارات المستهدفة

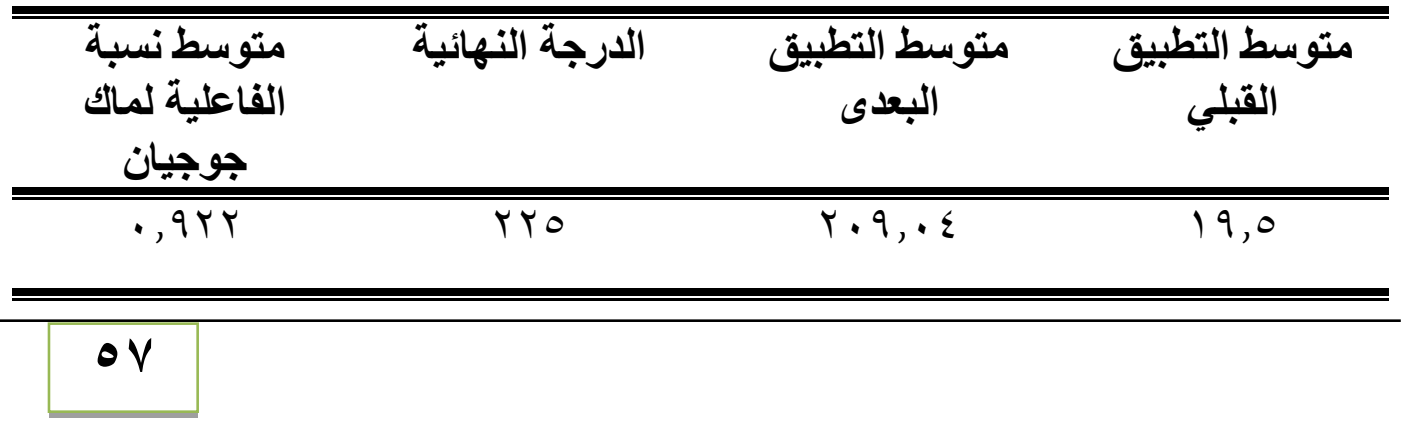




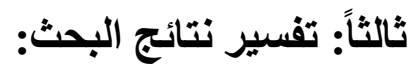

( ) تفسير النتائج المرتبطة بالتحصيل المعرفي لمهارات تصميم وإنتاج الاختبارات

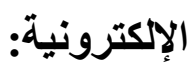

من النتائج السابقة يتضح أن البرنامج القائم على أدوات الويب . ب r لـه أثر فعـال في تنميـة التحصيل المعرفي لمهار ات تصميم و إنتاج الاختبار ات الإلكترونية، و هذا يتفق مع نتائج العديد من

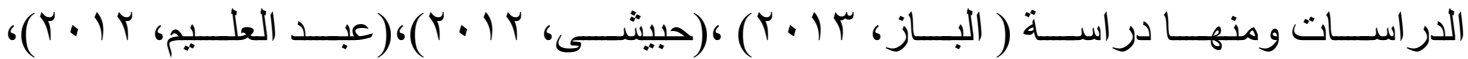

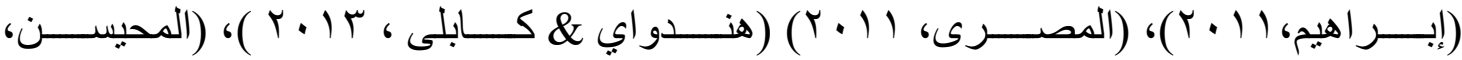

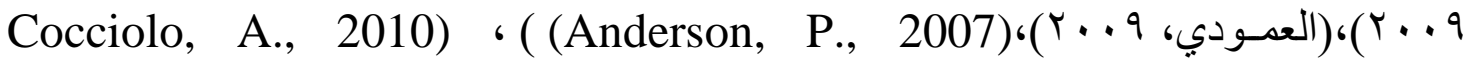

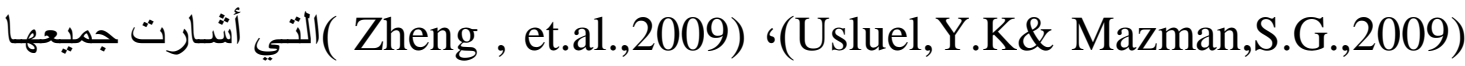
إلى فاعلية أدوات الويب . r. في زيادة التحصيل المعرفي للمتعلمين. وتُرجع الباحثة تلك النتائج إلى الأسباب التالية: •lستخدم الفيسبوك كأداة من أدوات الويب • r في مناقشة عناصر المحتوى التعليمي للبرنامج، و الذي وفر بيئة اجتماعية إلكترونية أناحت قدر ا كبير ا من التو اصل و المشاركة في حوارات، و ولئ نقاثنات تز امنية و غير نز امنية بين الطالبات بعضهن مع بعض وضله والباحثة، مما كان لـه أثر كبير في تحفيز وإثبات الذات لاى الطالبات، بالإضافة إلى الاستفادة من خبر ات الآخرين في جو حر

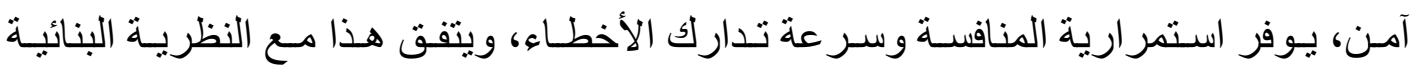

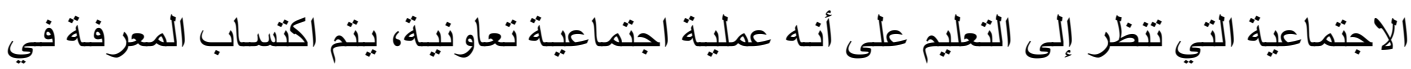

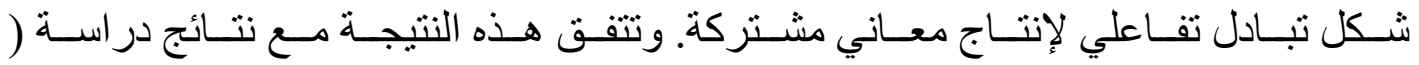

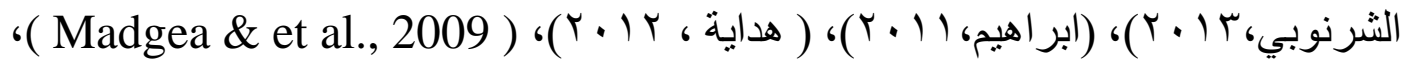
(Freishtat,R.L.,2009) الاجتماعي Face Book في تحصيل وتعلم الطلاب للمعارف المستهافة. •استخدام مدونة تعليمية كأحد أدوات الويب · ب ب في تقديم المحتوى التعليمي للبرنـامج ؛ فبعد الانتهاء من المناقثات عبر الـGroup على الفيسبوك يتم توجيه الطالبات إلى الصورة النهائية

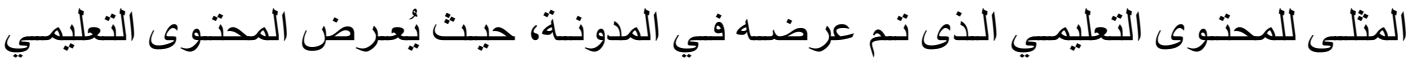

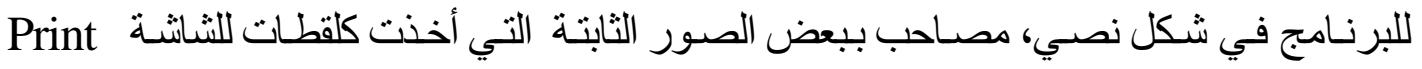
توضـح خطوات أداء المهارة بالتفصيل، بالإضـافة إلى تدعيم المدونـة برو ابط فيديو 
موجودة بقناة لليوتيوب youtube - خاصة بالمدونة فقط - تقدم شرحاً عملياً للمهار ات بطريقة

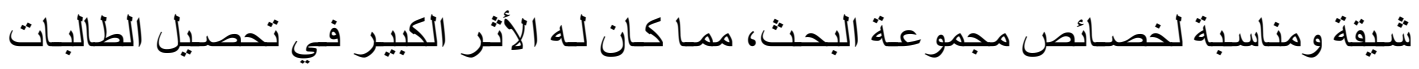

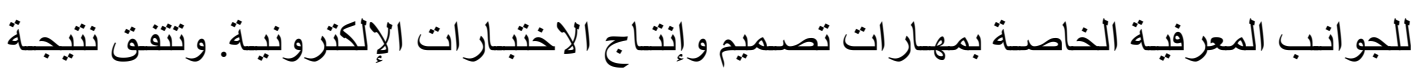

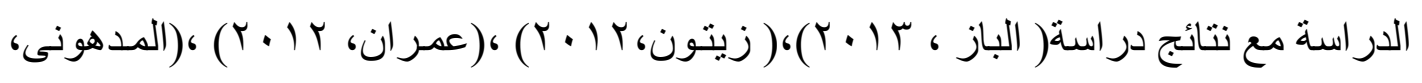

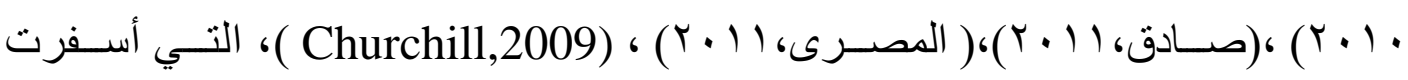

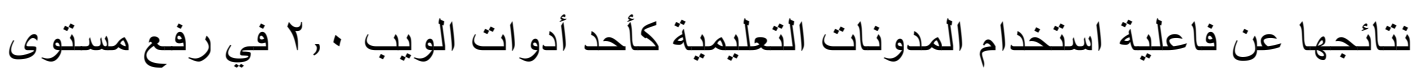
التحصيل المعرفي للمتعلمين. •وفر تقديم المحتوى التعليمي للبرنامج في مدونة نو عاً من المتعة و المرونة و الحرية في التعلم؛

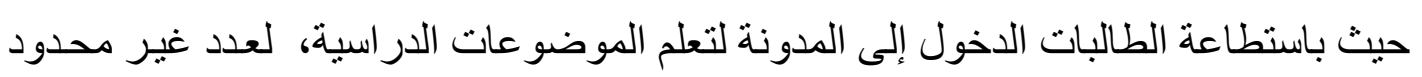

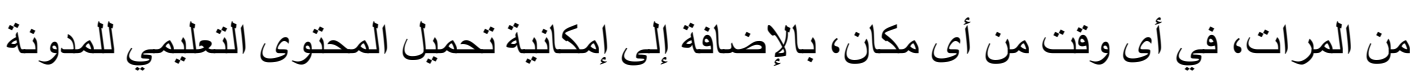

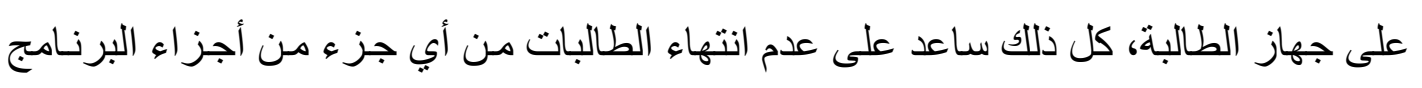
إلا بعد الاستيعاب الكامل له.

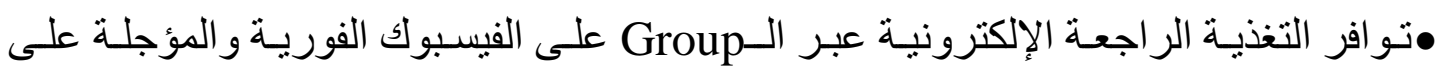

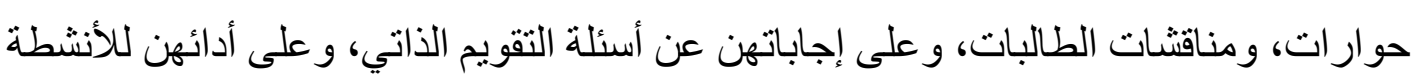
المكلفات بها. r الاكسير النتائج المرتبطة بتنمية الجوانب الأدائية لمهارات تصميم وإنتاج الاختبارات الإكترونية.

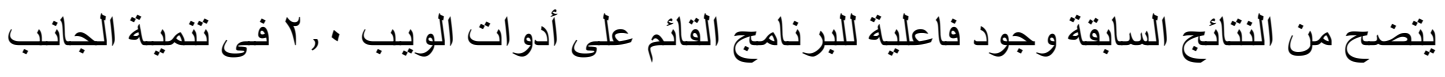

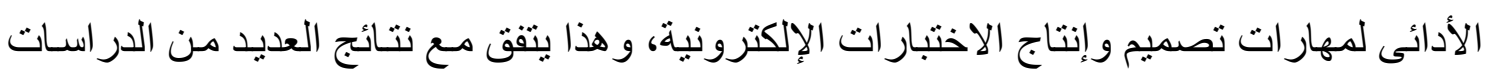

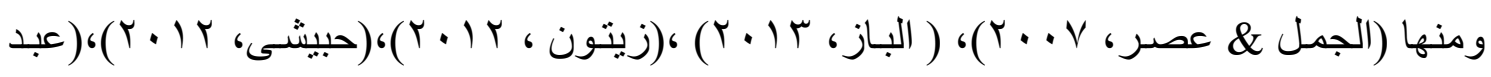

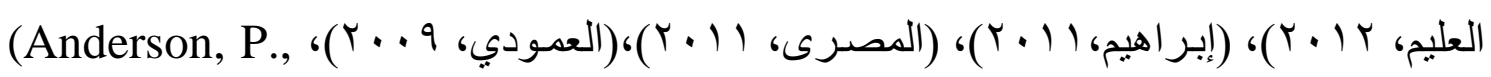
Zheng , ،(Usluel,Y.K\& Mazman,S.G.,2009)؛(Cocciolo, A., 2010) ، 2007)

.(et.al.,2009)

وتُرجِع الباحثة تلك النتائج إلى الأسباب التالية:

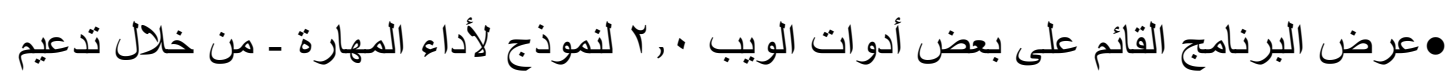

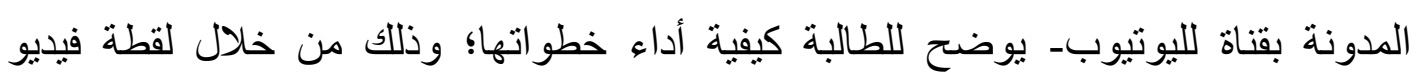


مصحوبة بتسجيل صوتي، مع إضافة بعض التأثيرات التوضيحية (نص-أسهر-تكبير-إضاءة-

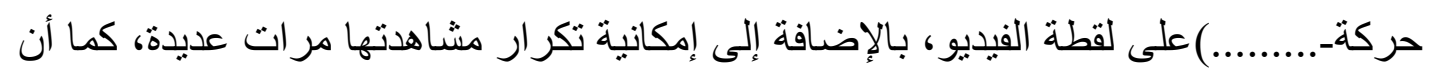

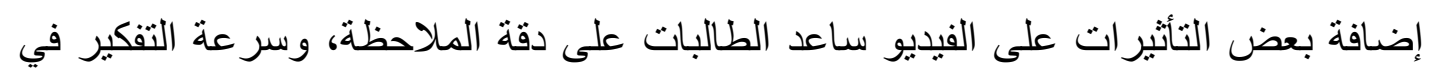

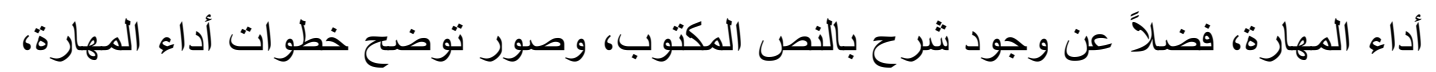

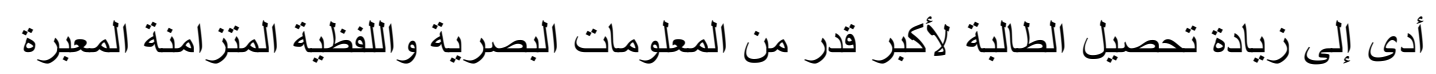

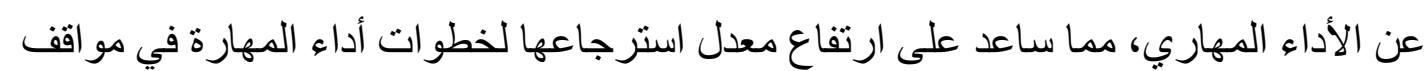

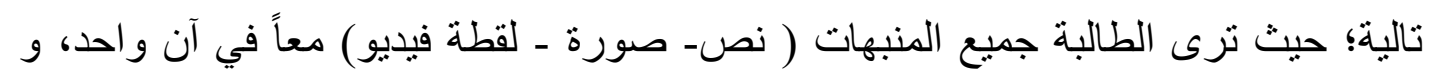
يتفق هذا مع نظرية التثفير المعرفي التي تؤكد أن المعلومات التي تم تقديمها في شكل بصري تصري

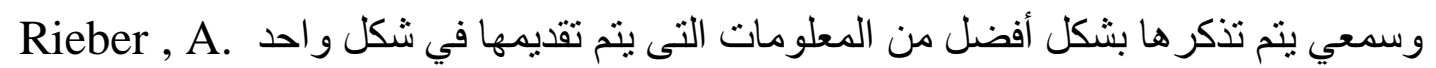

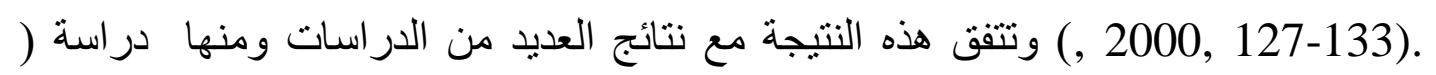

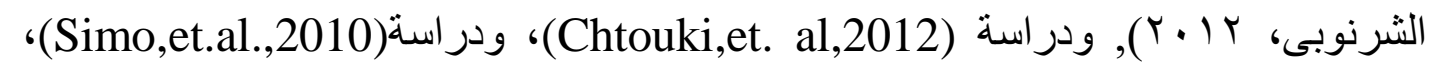
ودراسة(Snyder \& Burke,2008) التي أكدت على أن تقديم لقطات الفيديو في البرامج من خلال موقع اليوتيوب يُعد من أفضل المثيرات البصرية لتعلم المهارة. •وظيفية المادة العلمية ( المهار ات)؛ فهي ذات صفة عملية وفائدة في الحياة المهنية للطالبات بعد التخرج، مما أثار حماسهن لتعلم تلك المهار ات للاستفادة منها قبل الخدمة ( في التربية الميدانية)، وبعدها. •تكليف الطالبات بالقيام بالعديد من الأنشطة بعد كل مهارة، وعرضها أمام الجميع من خلال الـ Group

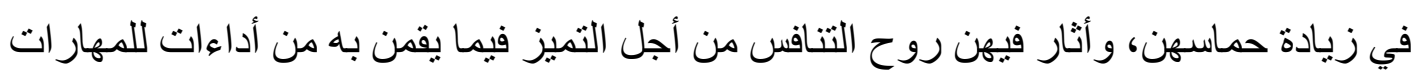
المكلفات بأدائها.

r) تفسير النتائج المرتبطة بجودة تصميم وإنتاج الاختبارات الإكترونية ( بطاقة تقييم المنتج). يتضح من النتائج السابقة وجود فاعلية للبرنامج القائم على بعض أدوات الويب . . ب فى زيادة

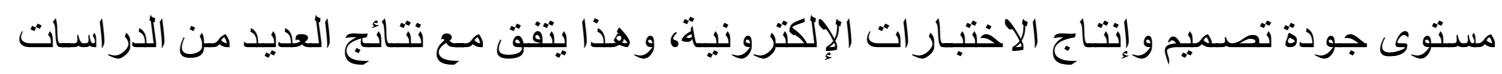

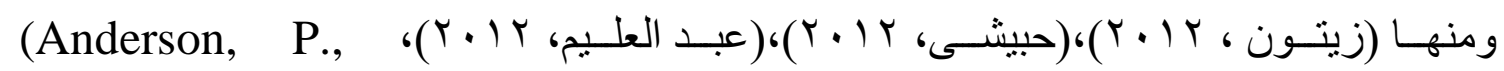


Zheng , ‘(Usluel,Y.K\& Mazman,S.G.,2009)؛(Cocciolo, A., 2010) ،2007)

(et.al.,2009)

\section{ويُُجِع الباحثة تلكت النتائج إلى الأسباب التالية:}

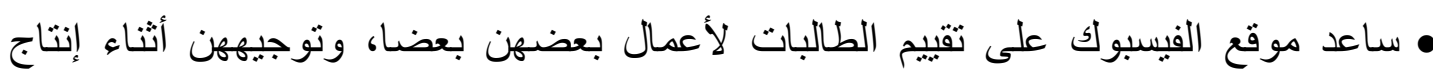
الاختبارات، بالإضافة إلى التخذية الراجعة الإلكترونية الفورية والمؤجلة من قِبل الباحثة، مما لإلى

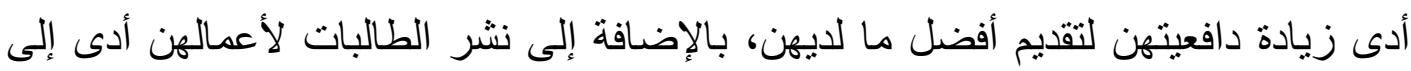

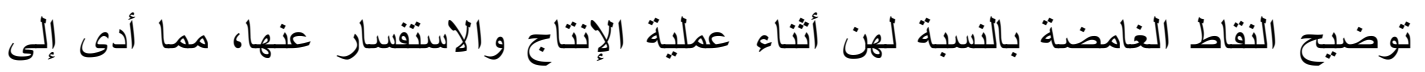

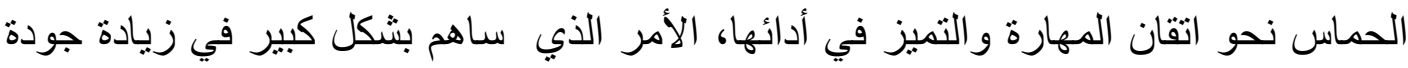
الاختبارات الإلكترونية المنتجة من قِبل الطالبات. وتتفق هذه النتيجة مع نتائج العديد من

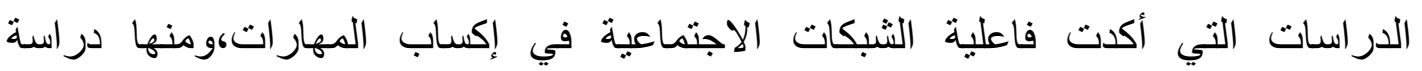

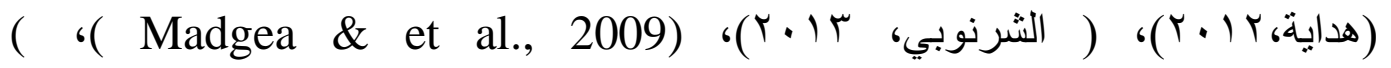

Freishtat,R.L.,2009) •تنو عت طبيعة الأنشطة التي مارستها الطالبات أثناء التعلم بين المشاهدة، و الملاحظة، و النقد،

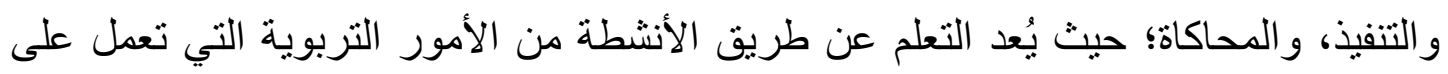

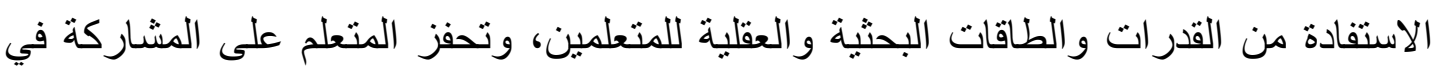
التوصل بنفسه إلى إنبات ذاته، وتعزيز قدر اته.

التوصيات:

في ضوء النتائج التي توصل إليها البحث يمكن تقديم التوصيات التالية:

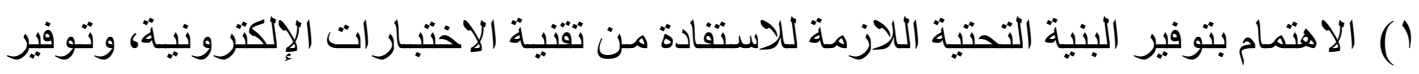

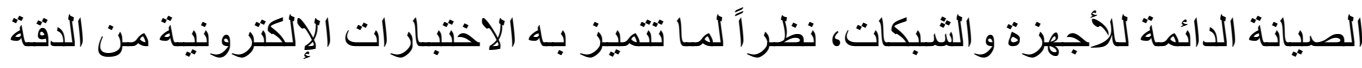

$$
\text { وتوفير الوقت والجها. }
$$

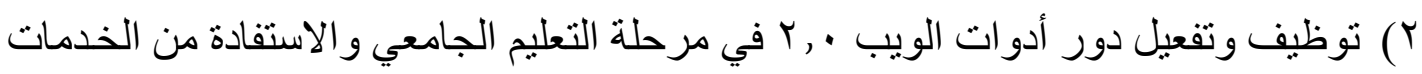
التي تقدمها. r) توظيف المدونات التعليمية، و الفيسبوك كملف إنجاز إلكترونى لأعمال الطلاب، يتم من خلالهما عرض الأعمال المتميزة للطلاب. 
؛) تدريب المتعلمين على تصميم و إنتاج اختبار ات إلكترونية وفق قائمة معايير تصميم و إنتاج

$$
\begin{aligned}
& \text { الاختبار ات الإلكترونية التي توصل إليها البحث الحالى. } \\
& \text { مقترحات بيحوث ودراسات اخرى: }
\end{aligned}
$$

( ) بحث فاعلية استخدام ثلاثة أنماط مختلفة من شبكات التو اصل الاجتماعى مثل: الفيسبوك، و التويتر، و الجوجل بلس عبر الإنترنت في التنمية المهنية المستدامة للمعلمين أثناء الخدمة.

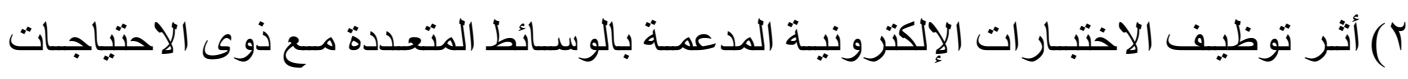

$$
\text { الخاصة. }
$$

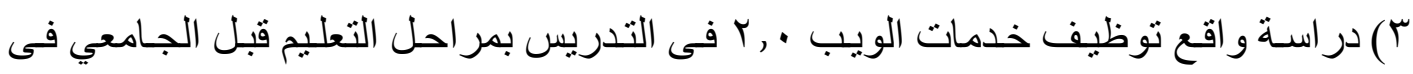
المملكة العربية السعودية.

ع) بحث أثر نوظيف الفيديو الرقمي في تقديم المعلومـات الحديثة لـى المهنيين في مجـال تكنولوجيا التعليه. 


\section{قائمة المراجع العربية}

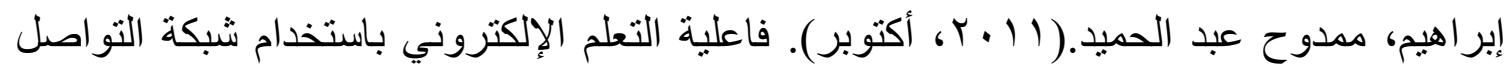

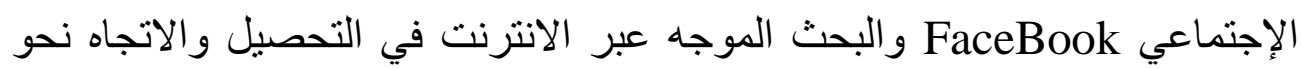

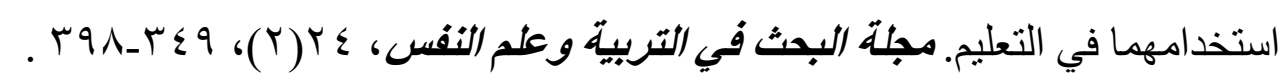

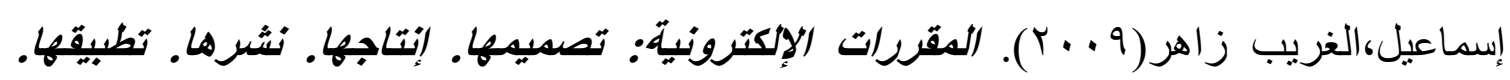
تقوييها .القاهرة: عالم الكتب.

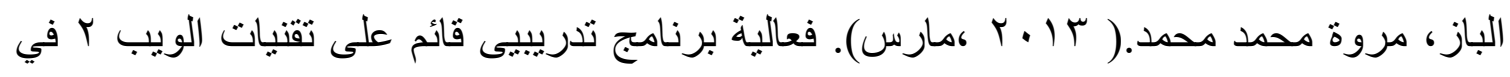

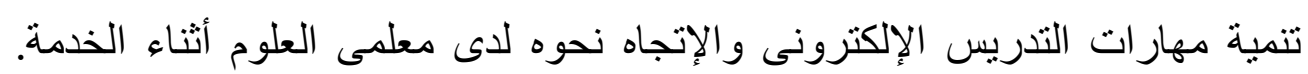

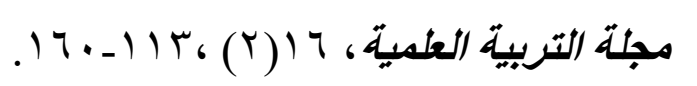

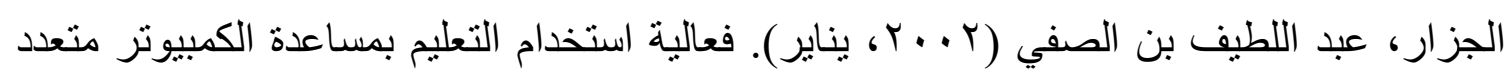

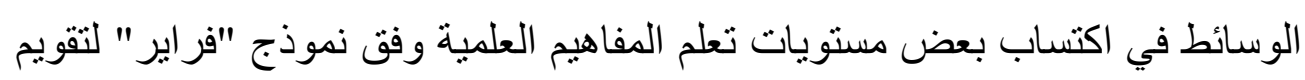

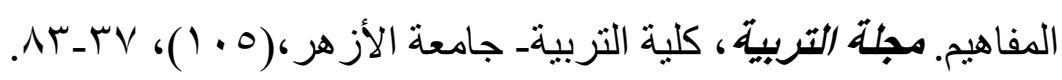

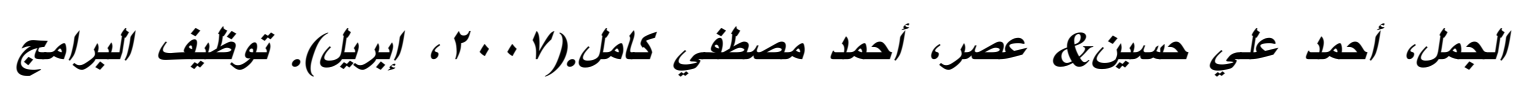

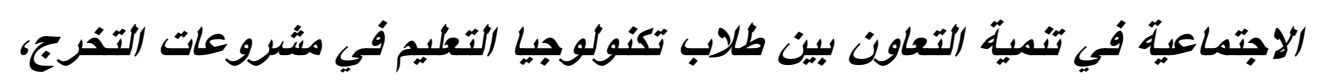

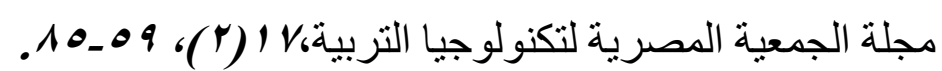
الحامدى، خالد حسن .(9 . . . أغسطس).الاختبارات الإلكترونية والتوظيف السليمبمجلة التعليم

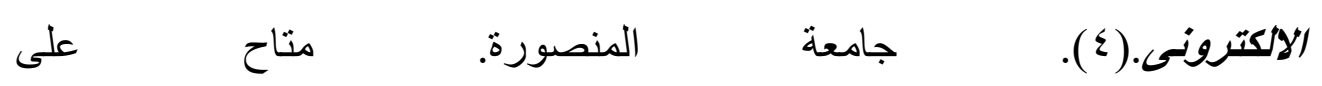
http://emag.mans.edu.eg/index.php?page=news\&task=show\&id= 143\&sessionID $=13$

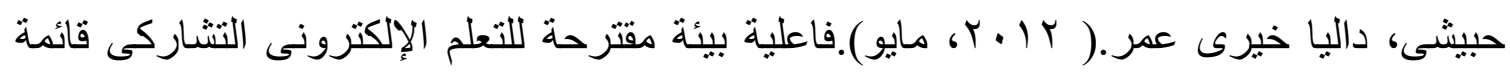

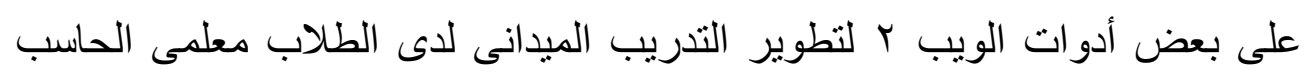

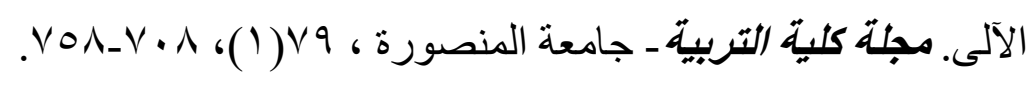

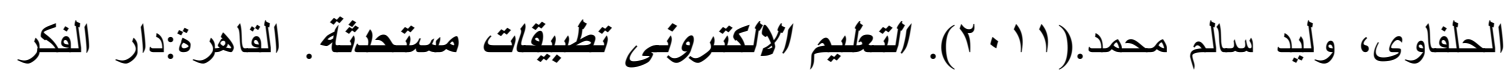
العربى.

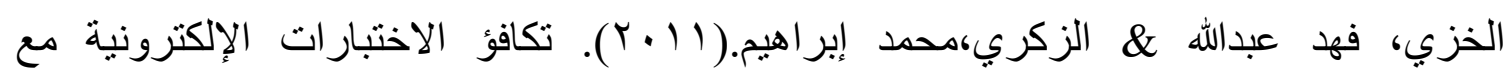
الاختبار ات الورقية في قياس التحصيل الدراسي:در اسة تجريبية على طلبة كلية التربية 


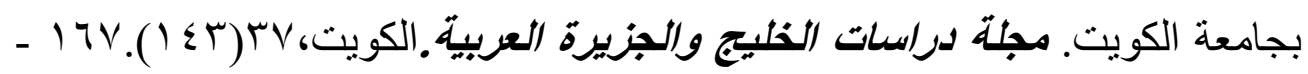

$$
.191
$$

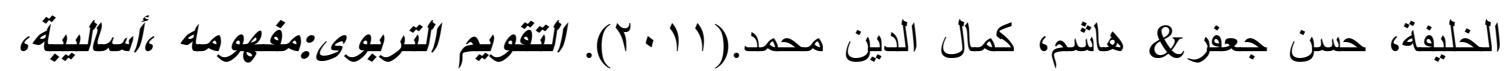

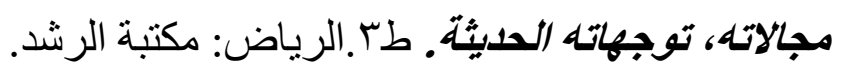

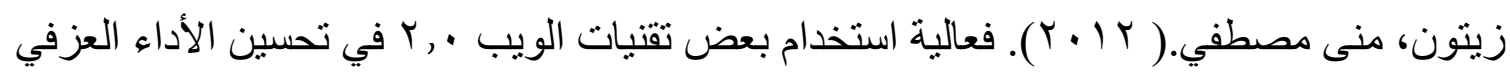
للآلة الريكورد لدى طلاب التربية الموسيقية. المؤتعر العلمى الأول للجمعية المصرية لئية

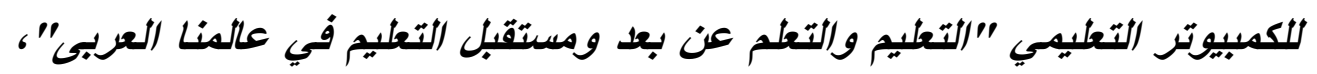

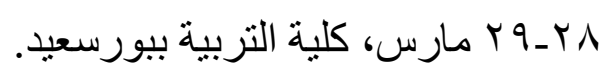

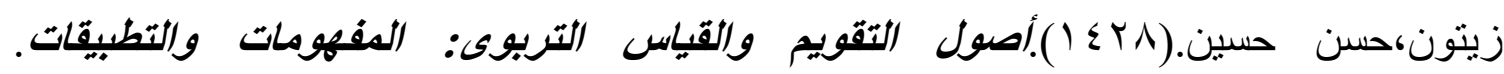
الرياض:الدار الصولتية.

السعدنى، محمد عبد الرحمن.(9 . . ب، يوليو).فعالية برنامج تدريبى لتتمية مهار ات أداء الاختبار ات الإلكترونية وأثره في التحصيل:دراسة حالة على مديرى الددارس السعودية.الثقافة

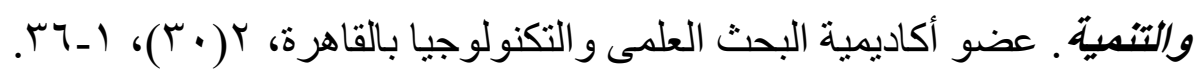

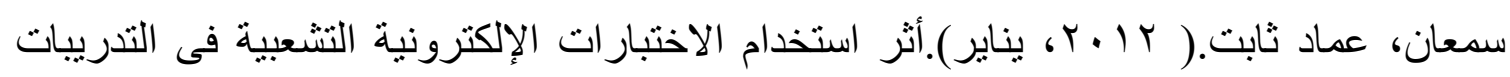

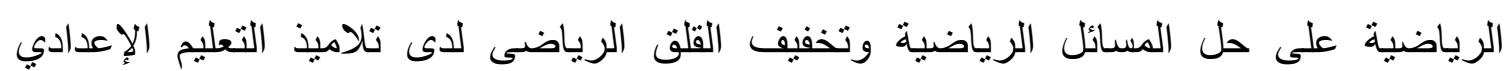

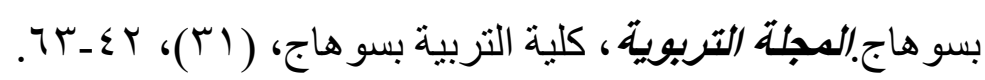

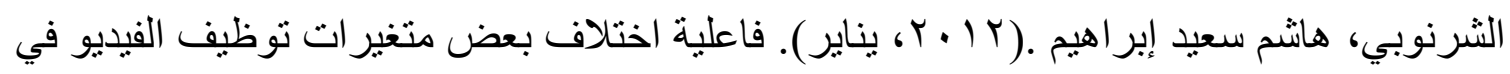

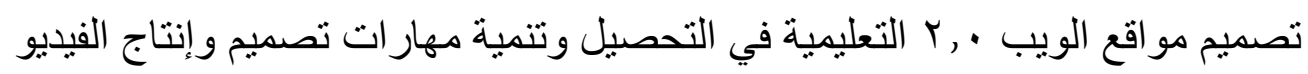

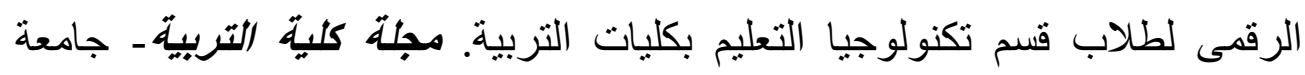

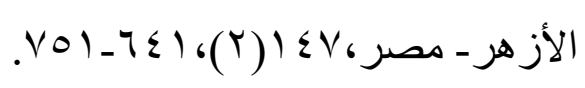

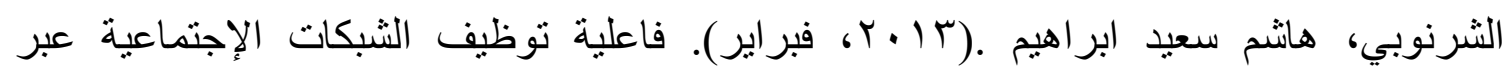

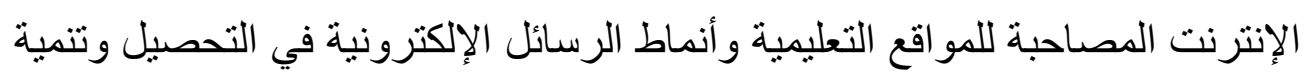

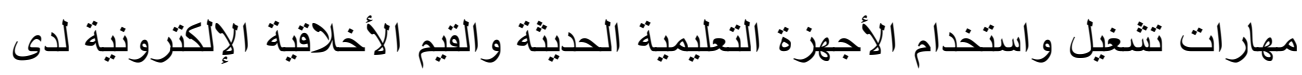
طلاب تكنولوجيا التعليم بكليات التربية. مجلة دراسات عربية في التربية وعلم النفس التس

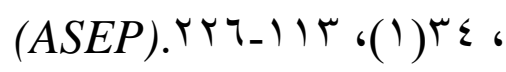

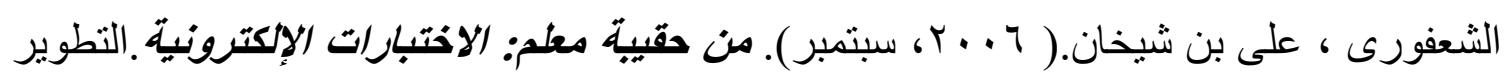




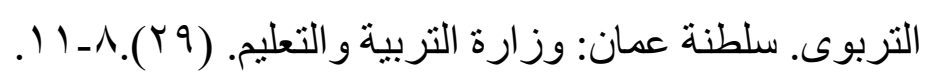

الثيخى،هاثم بن سعيد.(9 . . ، ، إبريل). دور الاستاذ الجامعى في تحقيق الجودة في مخرجات

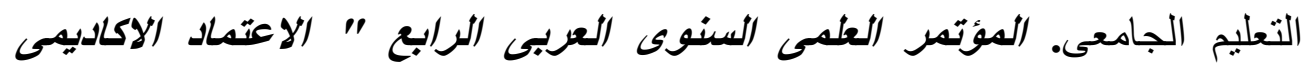

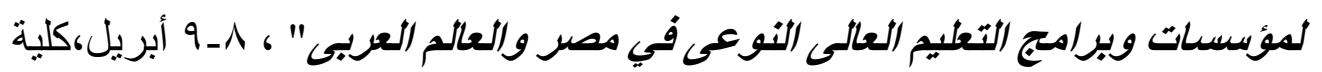

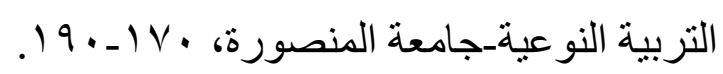

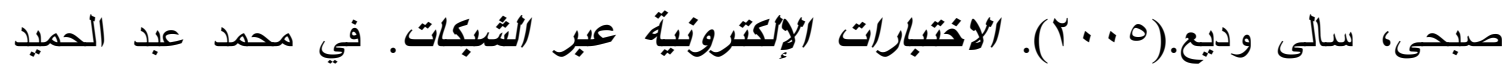

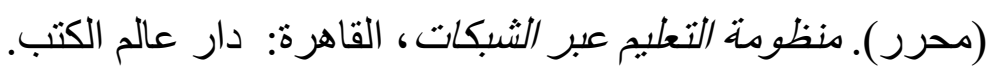

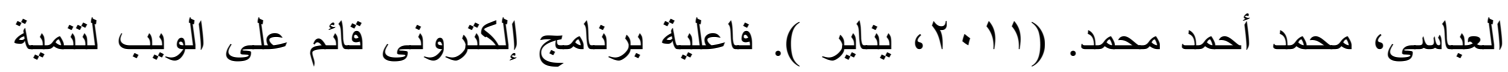

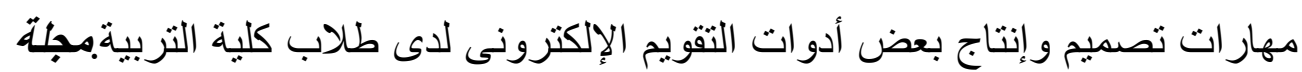

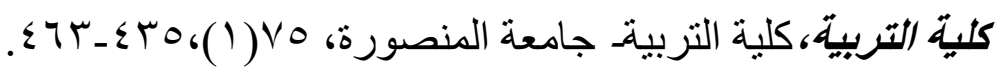

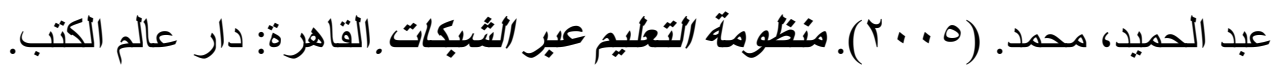

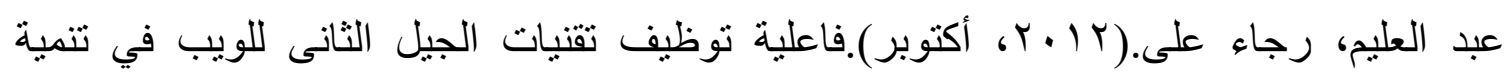

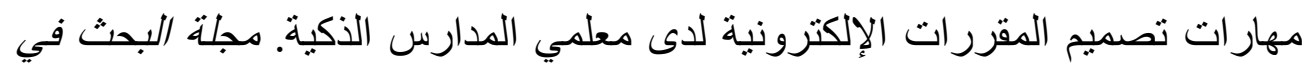

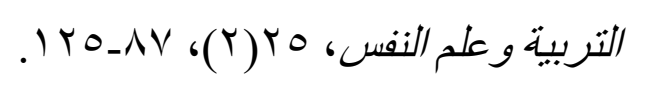

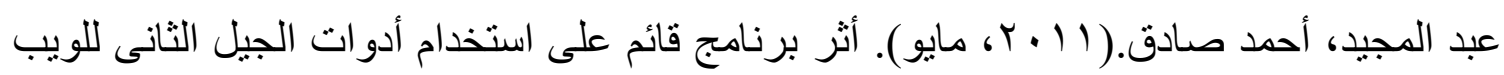

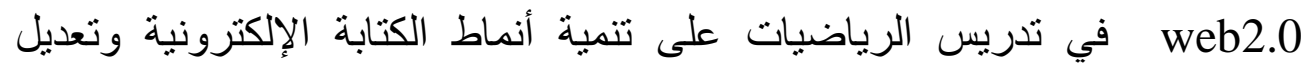

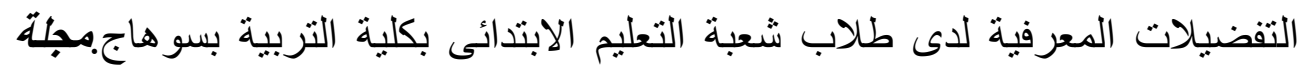

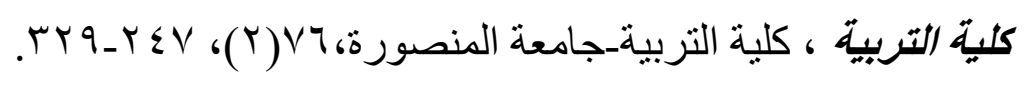
عزمي، نبيل جاد. (1 ، r). تكنولوجيا التعليم الإلكتروني. القاهرة: دار الفكر العريبي.

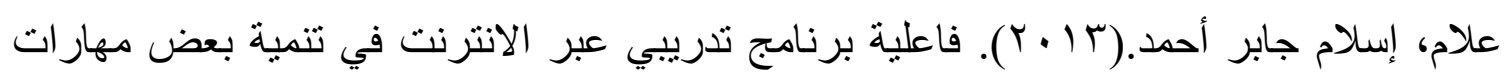

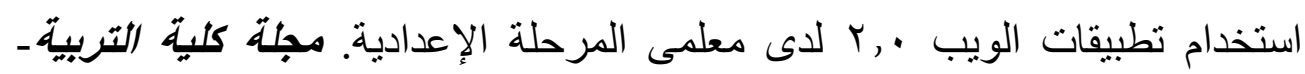

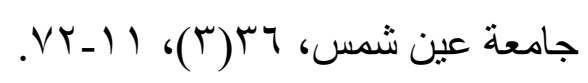

عمر ان، خالد عبد اللطيف.( r ( ـ r، يناير). فاعلية استخدام الددونات التعليمية في تدريس الجغر افيا

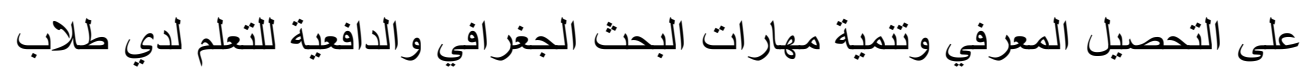

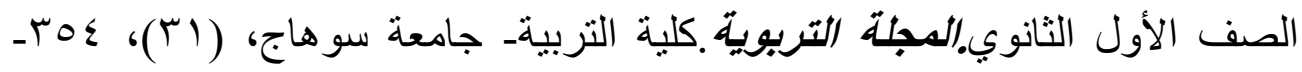




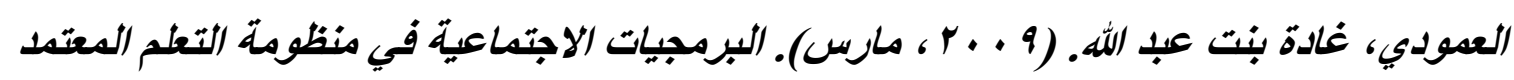

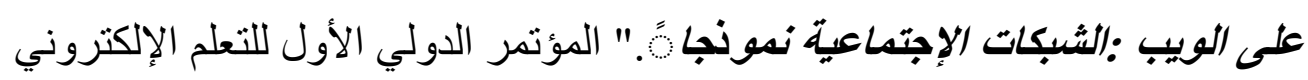

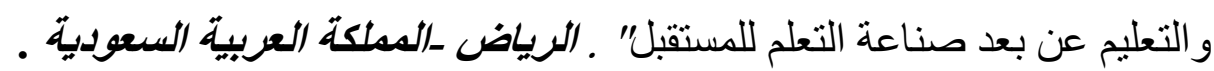

$\underline{\text { Retrieved }}$ Dec., 12 , 2010 from

http://eli.elc.edu.sa/2009/index.php?page=content عوض الله، محمد مصباح.(9 ٪ . ؟،إبريل ). معايير الجودة في الأداء المهنى لأعضاء هيئة التدريس

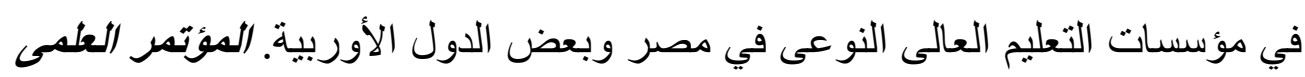

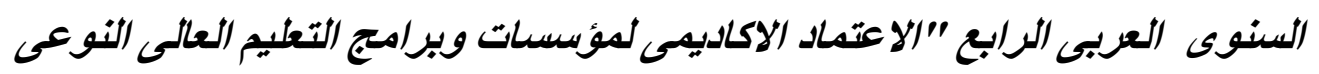

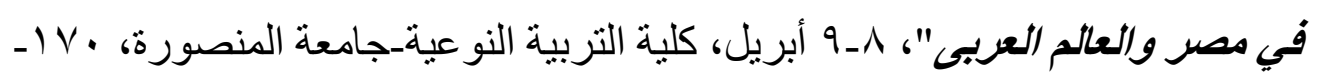
19 . القحطاني، محمد عايض.(• • • ب، إبريل).واقع استخدام خدمات الجيل الثاني للتعليم الإلكترونيlearning 2 جامعة الملك خالا. مجلة البحث في التربية وعلم النفس، كلية التربية- جامعة المنيا،

$$
\begin{aligned}
& \text { (1) } \\
& \text { VV-rT }
\end{aligned}
$$

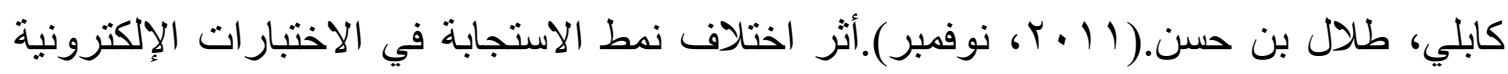

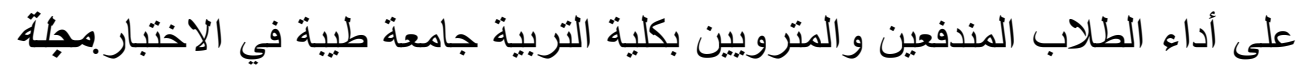

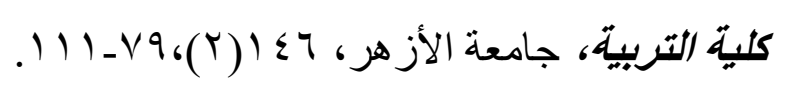

كامل، نبيل.(0 . . ، إبريل). منطلبات وتقنيات التصويب الآلى للاختبار ات و الو اجبات الددرسية.

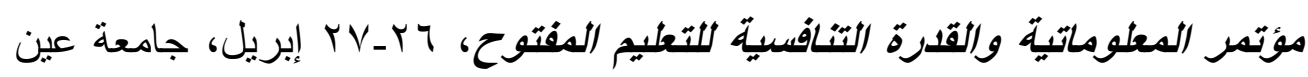

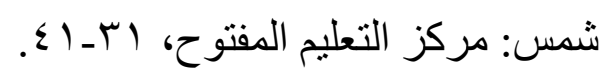

محود، إبراهيم يوسف محد..1 . . . ، بيونيو).أثر أختلاف شكل الاختبار الإلكترونس وبيئة التعلم

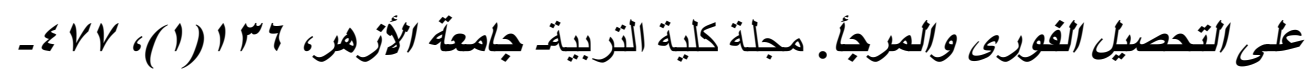

$$
\text { ort }
$$

المحيسن، أفنان بنت صالح. (9 . . ( ). استخدام تقنيات ويب 2.0 في التعليم والتعلم. رسالة ماجستير، جامعة طيبة. 
الددهوني، فوزية بنت عبد الله. (• • (Y). فاعلية استخدام المدونات التعليمية في تتمية التحصيل

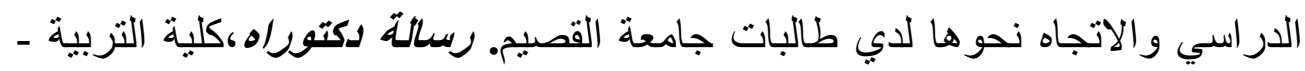
جامعة القصيم. المملكة العربية السعودية.

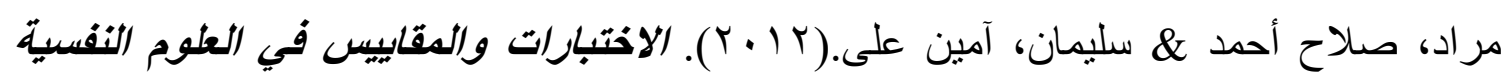
والتتريوية: خطوات إعدادها وخصائصها .القاهرة: دار الكتاب الحديث.

المصرى، سلوى فتحى محمود.(11 + Y، اكتوبر ). فاعلية استخدام مدونة تعليمية في زيادة تحصيل

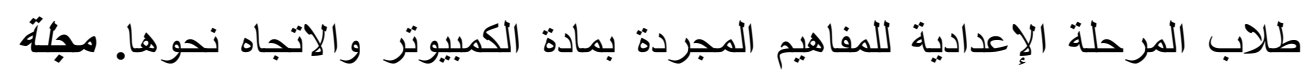

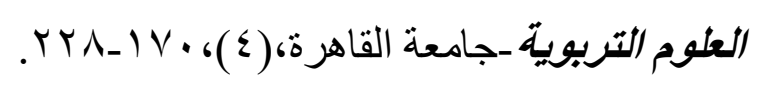

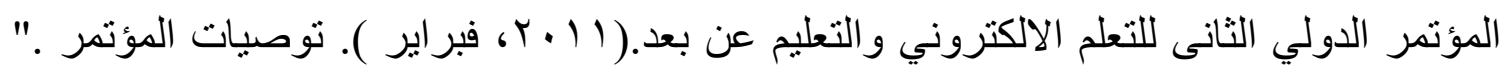

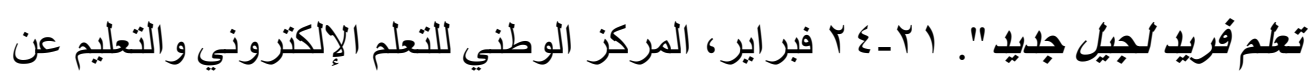
بوبعد:http:/www.wafa.com.sa/node/3056

المؤتمر العلىى الأول لكلية التربية.( ^. . r، فبراير ). نوصيات المؤتمر. "تكامل التربيية والعلوم

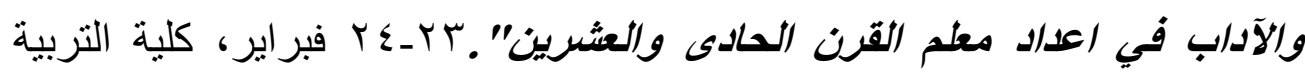

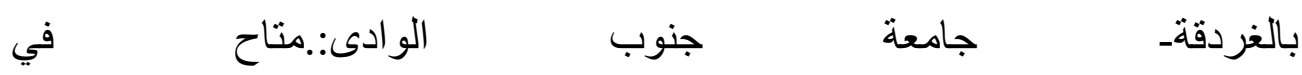
http://www.svu.edu.eg/arabic/links/News/NEWS92.htm

المؤتمر العلمي الحادي عشر للجمعية المصرية لتكنولوجيا التعليم.( ^. . r، مارس ). توصيات المؤتمر ." تكنولوجيا التعليم الإكترونسي وتحديات التطوير التريوي في الوطن

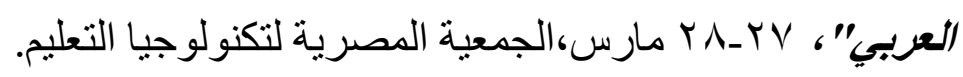

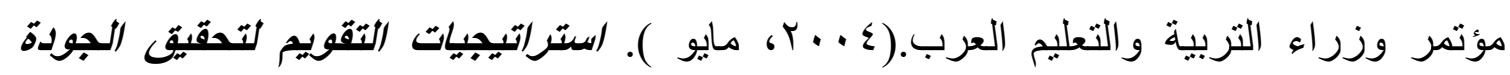

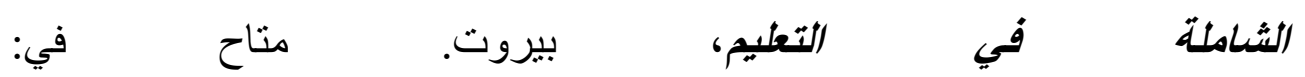

http://www.alecso.org.tn/index.php?option=com_content\&task=v iew\&id $=683$ نجم، محمد نجم.(999 (19). الامتحان باستخدام الحاسوب أم الامتحان بالورقة والقلم. (الحاسوب

$$
\text { والتقنيات. V. }
$$

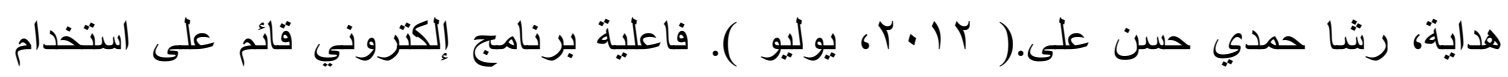

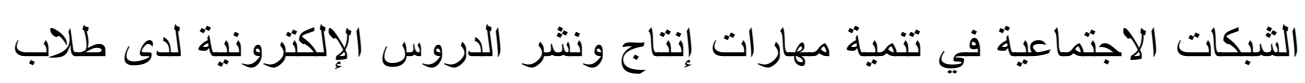




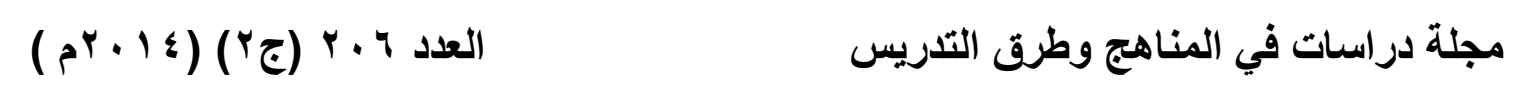

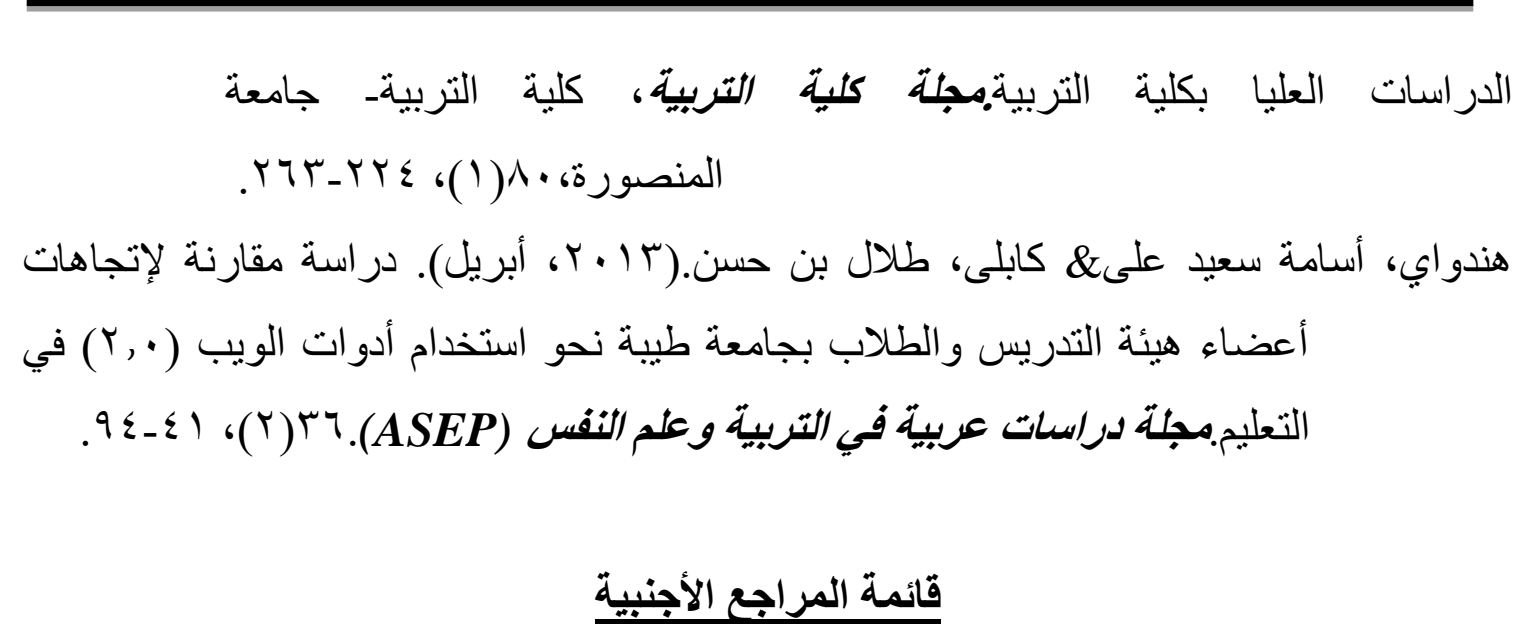

Ajjan, H., \& Richard H. (2008). Investigating faculty decisions to adopt Web 2.0 technologies: Theory and empirical tests, The Internet and Higher Education, (11)2, 71-80.

Anderson, P. (2007). What is Web 2.0? Ideas, technologies and implications for education. JISC TechWatch, Retrieved Jan,1, 2011 from http://www.jisc.ac.uk/media/documents/techwatch/tsw0701b.pdf

Basu,A.,\& et al.(2007, July). Multimedia Adaptive Computer based Testing: An Overview,Special Session,IEEE International Conference ,Beijing 2-5 July 2007,1850-1853.

Chatti, M., A., Klamma, R., Jarke, M.\& Naeve, A. (2009, July). The Web 2.0 Driven SECI Model Based Learning Process, The 7th IEEE International Conference on Advanced Learning Technologies (ICALT), $780-782$.

Choi , D.H., Kim,J. \& Kim, S.H. (2007). ERP Training with a Web-Based Electronic learning System: The Flow Theory Perspective". Int. J. Human-Computer Studies, 65, 223-243. Available at: www.sciencedirect.com

Chtouki,Y., Harroud, H.,Khalidi, M.,\&Bennani,S.(2012,June).The Impact of YouTube Videos on the Student's Learning. Information Technology 


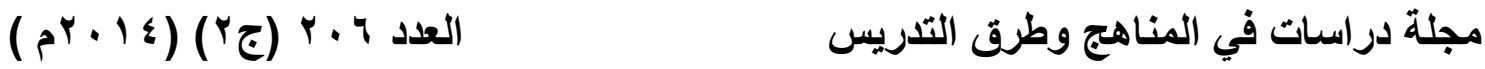

Based Higher Education and Training(ITHET),International

Conference, 21-23, available at:

http://ieeexplore.ieee.org/xpl/login.jsp?tp=\&arnumber=6246045\&url=http\%3A

\%2F\%2Fieeexplore.ieee.org\%2Fxpls\%2Fabs_all.jsp\%3Farnumber\%3D 6246045

Churchill, D.(2009). Educational Applications of Web2.0: Using Blogs to support Teaching and Learning. British Journal of Education Technology,

40(1), 179-183.

Cocciolo, A. (2010, July). Can Web 2.0 Enhance Community Participation in an Institutional Repository? The Case of Pocket Knowledge at Teachers College, Columbia University, The Journal of Academic Librarianship, 36(4), 304-312.

Deng,J.\&et al.(2005).The Design and Implementation of a Diagnostic Test. Journal of Information Science and Engineering 21,1007-1030.

Denise,W.(2009).Electronic Assessment: Marking, Monitoring and Mediating Learning, International Journal of Learning Technology, 2 (2),264-276. Freishtat,R. L.(2009, Dec). Learning in the technological frontier:facebook's public pedagogy and experiences with digital curriculum.PHD.arizona state university,USA,

Fujihara,Y.\& et al.(2009).Development of multimedia test system,Kobe University,Japan, available at: http://www.ascilite.org.au/asetarchives/confs/iims/1994/dg/fujihara.html http://www.as

Gabriela, G\& et al.(2011).Social aspects of web 2.0 technologies: Teaching or teachers' challenges? Procedia- Social and Behavioral Science, (15), 37683773. www.sciencedirect.com

Goktalay, S.,\& Ozdilek, Z. (2010) . Pre-service teachers' 


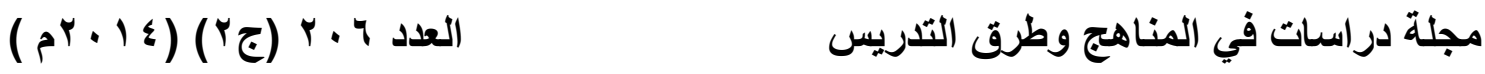

perceptions about web 2.0 technologies, Procedia - Social and Behavioral Sciences, 2(2), 4737-4741.

Greenhow, C., Robelia, B. \& Hughes, J., E. (2009, May). Research on Learning and Teaching With Web 2.0 : Bridging Conversations, Educational Researcher, 38(4), 280-283.

Grosseck, G. (2009, Jan).To use or not to use web 2.0 in higher education?, World Conference on Educational Sciences, Procedia - Social and Behavioral Sciences, 1(1), 478-482.

Jensen, M.,W. Johnson, D.,T.\& Johnson, R.(2002, Jan/ Feb). Impact of Positive Interdependence During Electronic Quizzes on Discourse and Achievement. Journal of Educational Research,(95)3,161-166

Karen, et al., (2010).Computer Based Testing: A Comparison of ComputerBased and Paper-and-pencil Assessment Academy of Educational Leadership Journal, 14(4). 117-125

Kear, K.,\& et al. (2010, Dec). From forums to wikis: Perspectives on tools for collaboration, The Internet and Higher Education, 13(4), 218-225.

Kesim, E., \& Agaoglu, E. (2007, July). A Paradigm Shift in Distance Education: Web 2.0 and Social Software, Turkish Online Journal of Distance Education-TOJDE,8(3),1302-6488, Retrieved Jan.,11,2011 from http://tojde.anadolu.edu.tr/tojde27/pdf/article 4.pdf

Khan,B., (2005). Managing E-learning Strategies: Design, Delivery, Implementation and Evaluation .Hershey, PA: Information Science Publishing

Madgea,C., et al.(2009,June). Facebook, Social integration and informal learning at university: It is more for socializing and talking to friends about work than for actually doing work .Learning and Technology,34(2),141-155. 
Martin,B.,Jan,S.,Mazdak,K.,\&Gereon, S.(2009,October). Innovative Electronic exam with voice in and output questions in medical terminology on a high taxonomic level.Medical Teacher,31(10),460-463

NCATE (2008).Professional standards Accreditation of Teacher Preparation Institutions. Available at :http://www.ncate.org/Portals/0/documents/Standards/NCATE\%20Stan dards\%202008.pdf

Nguyen, D.\& Allen, G.(2006).The Impact of Web-based Assessment and Practice on Students' Mathematics Learning Attitudes. The Journal of Computers in Mathematics and Science Teaching,25(3),251-280

Pommerich, M.(2004). Developing Computerized Version of Paper-and-Pencil T ests: Mode Effects for Passage-Based Test. The Journal of Technology, Learning, and Assessment,6(2),1-45.

Rieber, A.(2000). Computer Graphics and Learning. U.S.: Dollars.

Rosenfield, P., Vicino, S., \& Freda ,V.(2000). Evaluation assessment in orangutans : testing three-microcomputer-based survey systems . Journal of General Psychology . 83 (4) ,311- 325.

Simo, p. et al.(2010).Video Stream and Teaching Channels: quantitative analysis of the use of low-cost Educational videos on the web. Journal of Procedia Social and behavioral Sciences,2(2)2937-2941. Available at http://www.sciencedirect.com/science/article/pii/S1877042810004842 Snyder,S.\& Burk,S.,(2008).Using Youtube in the Classroom: How to guide.International Journal of Instructional Technology \& Distance Learning,5(4), Available at http://www.itdl.org/Journal/Apr_08/article03.htm Stowell, J.\& Bennett, D.(2010). Effects of Online Testing on Student Exam 


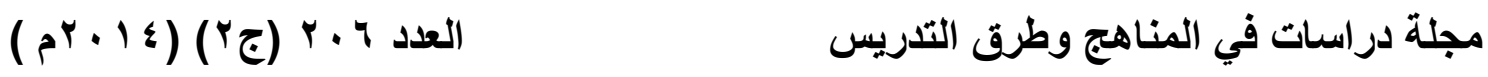

Performance and Test Anxiety. Journal of Educational Computing Research.42(2),161-171.

Sun, P.C., Tsai, R.J., Finger, G.,Chen,Y.Y.\&Yeh, D.(2008). What Drives a Successful E-Learning? An Empirical Investigation of the Critical Factors Influencing Learner Satisfaction. Computers \& Education,. 50,1183-1202. Available at www.sciencsdirection.com

Sutton, R. E.(2004). Teaching under high-stakes testing: Dilemmas and decisions of a teacher educator. Journal of Teacher Education, 55(5),463-475.

Suyder,S. \& Burke,C.(2008,Nov). Students' Perceptions of Youtube Usage in the College Classroom. International journal of Instructional Technology and Distance Learning.11(5),13-22

Usluel, Y. K\& Mazman,S.G.(2009). Adaption of web 2.0 tools in distance education. Social and Behavioral Science.1(1).818-823. Available at WwW.sciencsdirection.com

Wang Y.S.,Wang, H.Y, \& Shee, D.Y.(2007). Measuring E-learning Systems Success in an Organizational Context: Scale Development and Validation. Computers in Human Behavior, 23, 1792-1808, Available at: www.sciencedirect.com

Wang, Y., \& Duan, F. (2008). study of personalized teaching system Based on web 2.0, International symposium on computational Intelligence and Design, IEEE Computer Society Washington, USA.Retrieved Jan,2,2011 from http://www.computer.org/portal/web/csdl/doi/10.1109/ISCID.2008.165 Weller, M. \& Dalziel, J. (2007). Bridging the gap between web 2.0 and higher education. Retrieved Jan,2,2011 from 


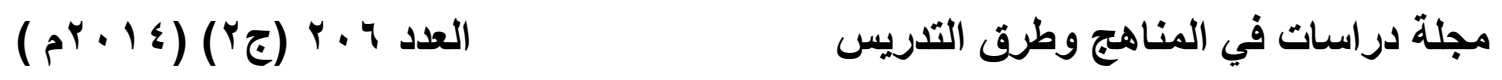

http://lams2007sydney.lamsfoundation.org/pdfs/04g.pdf

Zheng, W., Zhao, Ch., Liu, Z., \& Wang, F. (2009, March). Research and Application of Collaborative Knowledge Building Model Based on Web2.0, First International Workshop on Education Technology and Computer Science, China. 